\title{
DEFENCE ARGUMENTS IN INVESTMENT ARBITRATION
}

\author{
Jorge E. Viñuales*
}

$\begin{array}{lr}\text { I. Overview } & 13\end{array}$

II. Analysis 18

1. Preliminary Observations 18

2. Defence Arguments Operating at the Level of the Primary Norm 19

2.1. General Scope of and Reliance on the Applicable Treaty 19

$\begin{array}{ll}\text { 2.1.1. Introduction } & 19\end{array}$

2.1.2. Defence Arguments Concerning the Perimeter of
the Treaty

Exclusion of Taxation Measures $\quad 21$

Non-Precluded Measures Protecting Essential Security Interests 26

Illegality of the Investment $\quad 30$

2.1.3. Defence Arguments Concerning the Entitlement to Rely on the Treaty 34

International Public Policy 35

Estoppel $\quad 37$

Acquiescence $\quad 39$

Extinctive Prescription $\quad 40$

Abuse of Right $\quad 42$

Corruption $\quad 46$

Wilful Blindness 49

2.2. Specific Scope of the Primary Norm 51

Scope of the Prohibition of Performance Requirements (Article 1106(5) of the NAFTA) 52

Reservation of Specifically Identified Measures (Article 1108(1) of the NAFTA) 53

Public Procurement Carve-Outs (Article 1108(7)(a) of the NAFTA) 55

Annexes Carving Out Measures for Certain Purposes 57

2.3. Assessment of Breach of the Primary Norm 59

Exercise of Police Powers $\quad 59$

Margin of Appreciation $\quad 69$

Public Interest Counterclaims $\quad 72$

* Harold Samuel Professor, University of Cambridge, Member (Associé) of the Institut de Droit International, and Co-General Editor, ICSID Reports. The views expressed in this study are strictly in my academic capacity. 
3. Defence Arguments Operating at the Level of Secondary Norms 77

3.1. Specific Excuses $\quad 77$

Exceptions $\quad 78$

Emergency Clauses (War and Extended

War Clauses) $\quad 78$

3.2. Generally Available Excuses $\quad 81$

Necessity $\quad 82$

Countermeasures $\quad 87$

Théorie de l'imprévision (Unforeseeability or Hardship) $\quad 89$

Force Majeure $\quad 92$

3.3. Quantum Reduction 94

Clean Hands Doctrine $\quad 95$

Contributory Fault $\quad 96$

Duty to Mitigate Damages $\quad 98$

III. Concluding Observations 99

Appendix: List of Cases Covered in this Study 100

1. This volume of the ICSID Reports is organised around a category which has neither clear contours nor, in earnest, any technical existence, as such, in international law. ${ }^{1}$ Whereas the term "defence", or some subcategories of this genus, such as "affirmative defences" or even very specific types of defences such as "duress", may be familiar to lawyers in the common law tradition, its use in international law can only be by analogy. The term encompasses, under a single convenient expression, a wide variety of legal concepts that can be mobilised not only by the respondent but also by the claimant in arbitration proceedings. This initial observation is subject to two qualifications. First, despite the absence of a technical category of "defences" or "affirmative defences" in international law, concepts such as "estoppel" or "force majeure", which are defences in domestic law, also operate in international law. Such concepts are indeed recognised by international law but they do not carry all the implications that domestic legal orders may attach to them by virtue of their domestic characterisation as

\footnotetext{
1 International courts and tribunals are often asked to qualify defence arguments in certain ways, which carry legal implications. In some cases, they endorse such qualification, possibly because of the legal background of the adjudicators (e.g. Pope \& Talbot Inc. v. Canada, NAFTA Case (UNCITRAL Rules), Award in Relation to Preliminary Motion by the Government of Canada (24 February 2000), [Pope \& Talbot v. Canada - Interim Award] para. 11). Yet, when a general statement on such qualification is made, the focus is on the specificity of each legal measure, provision and case. See e.g. India Additional and Extra-Additional Duties on Imports from the United States, AB Report (17 November 2008), WT/DS360/AB/R [India - Additional Duties], para. 189 ("[i]n considering the responsibilities of the parties with respect to the burden of proof, we recall the Appellate Body's observation in prior reports that the requirements of a prima facie case in the context of a particular dispute will be judged case by case, provision by provision, and measure by measure") and the references therein.
} 
"defences" or "affirmative defences". 2 The second is that defences from domestic law may be applicable in investment arbitration and commercial arbitration proceedings as such, typically when the case raises contractual matters and the domestic law applicable to the contract or otherwise applicable in the proceedings recognises specific defences. To mark these two qualifications, this study uses the expression "defence arguments", which emphasises the analytical - as opposed to the technical - nature of the category.

2. The broad and diverse category of defence arguments can be approached from a range of perspectives. Some commentators have discussed one specific defence argument (e.g. the police powers doctrine, ${ }^{3}$ pleas of illegality, ${ }^{4}$ countermeasures, ${ }^{5}$ force majeure $e^{6}$ or necessity ${ }^{7}$ ) or a subset of them (e.g. clauses reserving non-precluded measures ${ }^{8}$ or circumstances precluding wrongfulness ${ }^{9}$ ). Some others have focused on the interests protected, such as the fight against corruption, ${ }^{10}$ the protection of human rights ${ }^{11}$ or the preservation of the environment. ${ }^{12}$ Yet some others have

2 This caveat is sometimes omitted by tribunals, which extrapolate the rule of domestic law (and its characterisation as an "affirmative defence" under the relevant domestic law, with its implications) to the level of international law, as if the two norms were one and the same. See e.g. Pope \& Talbot v. Canada - Interim Award, para. 11 (characterising the respondent's argument that a claim is time barred under the limitation period of Article 1116(2) as an argument "in the nature of an affirmative defence" and debatably placing the burden of proof on the respondent, whereas it befalls the claimant to establish that the claim is timely). Yet, there may be important differences in the operation of such rules. An example is provided by the doctrines of "extinctive prescription" or of "clean hands", whose extrapolation to the international plane presents several problems discussed later in this study.

3 See e.g. I. Brownlie, Principles of Public International Law (Oxford University Press, 7th ed., 2008), at 533-6; A. Newcombe, "The Boundaries of Regulatory Expropriation in International Law" (2005) 20 ICSID Review 1; G. H. Aldrich, "What Constitutes a Compensable Taking of Property? The Decisions of the Iran-United States Claims Tribunal" (1994) 88 American Journal of International Law 585; G. C. Christie, "What Constitutes a Taking of Property under International Law" (1962) 38 British Yearbook of International Law 307.

4 See e.g. Z. Douglas, "The Plea of Illegality in Investment Treaty Arbitration" (2014) 29 ICSID Review 155.

5 See e.g. M. Paparinskis, "Investment Arbitration and the Law of Countermeasures" (2008) 79 British Yearbook of International Law 264.

6 See e.g. F. Paddeu, "A Genealogy of Force Majeure in International Law" (2011) 82 British Yearbook of International Law 381.

7 See e.g. Ch. Leben, "L'état de nécessité dans le droit international de l'investissement" (2003) 3 Les Cahiers de l'arbitrage 47; R. D. Sloane, "On the Use and Abuse of Necessity in the Law of State Responsibility" (2012) 106 American Journal of International Law 447.

8 See e.g. W. W. Burke-White, A. von Staden, "Investment Protection in Extraordinary Times: The Interpretation and Application of Non-Precluded Measures Provisions in Bilateral Investment Treaties" (2008) 48 Virginia Journal of International Law 307; D. A. Desierto, Necessity and National Emergency Clauses. Sovereignty in Modern Treaty Interpretation (Leiden: Martinus Nijhoff, 2012).

9 See e.g. F. Paddeu, Justification and Excuse in International Law (Cambridge University Press, 2018); C. Binder, "Circumstances Precluding Wrongfulness", in M. Bungenberg, J. Griebel, S. Hobe, A. Reinisch (eds), Handbook on International Investment Law (Baden-Baden/Oxford: Nomos/Hart, 2015), pp. 442-80.

10 See e.g. A. Llamzon, Corruption in International Investment Arbitration (Oxford University Press, 2014).

11 See e.g. P.-M. Dupuy, F. Francioni, E.-U. Petersmann (eds), Human Rights in International Investment Law and Arbitration (Oxford University Press, 2009); U. Kriebaum, Eigentumsschutz im Völkerrecht. Eine vergleichende Untersuchung zum internationalen Investitionsrecht sowie zum Menschenrechtsschutz (Berlin: Duncker \& Humblot, 2008).

12 See e.g. J. E. Viñuales, Foreign Investment and the Environment in International Law (Cambridge University Press, 2012) [Viñuales 2012]. 
organised their analysis by reference to the effects on the proceedings or the "stage" at which certain defence arguments intervene. ${ }^{13}$ There is no single manner to organise such a discussion and, indeed, there cannot be one recognised manner given the wide variety of heterogeneous concepts brought together under the broad heading of "defence arguments".

3. For this reason, the analytical organisation must follow the specific purpose of the context in which it unfolds. In the context of this volume, the purpose is threefold: (i) to provide an integrated study of the legal concepts discussed in the decisions selected for this volume of the ICSID Reports; (ii) to place such concepts and decisions in the wider context of the growing body of international decisions from investment arbitration tribunals and other adjudicatory bodies, and (iii) to analyse the operation of these concepts in a manner which is relevant both for the practice of international investment law and for the wider conceptual understanding of the field.

4. On this basis, the study consists of three main sections. The first focuses on the "wood" and provides an overview of the defence arguments covered by the investment and commercial arbitration decisions reported in this volume. The second discusses the "trees", namely each one of the defence arguments covered in the reported cases as well as some related arguments. These are not the only defences that have been relied on in investment arbitration. Others include distress,${ }^{14}$ duress, ${ }^{15}$ coercion, ${ }^{16}$ the exceptio inadimplenti non est adimplendum ${ }^{17}$

13 See e.g. Y. Shany, Questions of Jurisdiction and Admissibility before International Courts (Cambridge University Press, 2015); M. Waibel, "Investment Arbitration: Jurisdiction and Admissibility", in M. Bungenberg, J. Griebel, S. Hobe, A. Reinisch (eds), Handbook on International Investment Law (Baden-Baden/Oxford: Nomos/Hart, 2015), pp. 1212-87; B. Sabahi, K. Duggal, N. Birch, "Limits on Compensation for Internationally Wrongful Acts", in M. Bungenberg, J. Griebel, S. Hobe, A. Reinisch (eds), Handbook on International Investment Law (Baden-Baden/Oxford: Nomos/Hart, 2015), pp. 1115-29.

See e.g. S. Szurek, "Circumstances Precluding Wrongfulness in the ILC Articles: Distress", in J. Crawford, A. Pellet, S. Olleson (eds.), The Law of International Responsibility (Oxford University Press, 2010), pp. 481-9.

15 See e.g. S. A. Smith, "Contracting under Pressure: A Theory of Duress" (1997) 56 Cambridge Law Journal 343.

16 See e.g. G. Napoletano, Violenza e trattati nel diritto internazionale (Milano: Giuffrè, 1977); H. G. de Jong, "Coercion in the Conclusion of Treaties. A Consideration of Articles 51 and 52 of the Convention on the Law of Treaties" (1984) 15 Netherlands Yearbook of International Law 209; G. Di Stefano, "Article 51: Coercion of a Representative of a State", in O. Corten, P. Klein (eds.), The Vienna Conventions on the Law of Treaties. A Commentary (Oxford University Press, 2011), pp. 1179-98; O. Corten, "Article 52: Coercion of a State or of an international organization by the threat of the use of force", in Di Stefano, "Article 51: Coercion of a Representative of a State", in O. Corten, P. Klein (eds.), The Vienna Conventions on the Law of Treaties. A Commentary (Oxford University Press, 2011), pp. 1201-17.

17 See e.g. in B. Simma, C. Tams, "Article 60: Termination or Suspension of the Operation of a Treaty as a Consequence of its Breach", in O. Corten, P. Klein (eds.), The Vienna Conventions on the Law of Treaties. A Commentary (Oxford University Press, 2011), pp. 1351-77; R. Pisillo Mazzeschi, Risoluzione e sospensione dei trattati per inadempimento (Milan: Guiffrè, 1984); B. P. Sinha, Unilateral Denunciation of Treaty Because of Prior Violations of Obligations by Other Party (Dordrecht: Martinus Nijhoff, 1966); J. Crawford, S. Olleson, "The Exception of Non-Performance: Links between the Law of Treaties and the Law of State Responsibility" (2000) 21 Australian Yearbook of International Law 55. 
or the rebus sic stantibus clause. ${ }^{18}$ But given the context and purpose of this study, such arguments are not analysed here. The material covered in this study includes many concepts examined in some of my previous work, ${ }^{19}$ on which I rely in this study in an effort to provide a more general and integrative treatment of the subject. The third and final section offers brief concluding observations.

\section{OVERVIEW}

5. Following the content selected for the present volume, this study covers twenty-three defence arguments, which are discussed in detail in one or more of the reported decisions, as well as three other related defence arguments. Figure 1 summarises the material reported by connecting each one of the twenty-three defence arguments to the relevant reported decisions, organised by year of publication. Some important decisions have not been included in this volume because they were reported in previous volumes. ${ }^{20}$ Examples include the award in Saluka v. Czech Republic (a major precedent for the police powers doctrine), ${ }^{21}$ the decision on liability in $L G \& E \mathrm{v}$. Argentina ${ }^{22}$ or that of the Ad Hoc Committee in CMS v. Argentina ${ }^{23}$ (both important precedents for the operation of non-precluded measures and the customary necessity defence).

18 See e.g. M. Shaw, C. Fournet, "Article 62: Fundamental Change of Circumstances", in O. Corten, P. Klein (eds.), The Vienna Conventions on the Law of Treaties. A Commentary (Oxford University Press, 2011), pp. 1411-33; A. Poch de Caviedes, "De la clause 'rebus sic stantibus' à la clause de révision dans les conventions internationales" (1966) 118 RCADI 105-208. The rebus sic stantibus clause is discussed in the present study through the prism of domestic law concepts such as "hardship" and the unforeseeability theory.

19 In addition to Viñuales 2012, this study relies, in part, on the following work: "Seven Ways of Escaping a Rule: Of Exceptions and their Avatars in International Law", in L. Bartels, F. Paddeu (eds), Exceptions in International Law (Oxford University Press, forthcoming 2020) [Viñuales 2020]; "Foreign Investment and the Environment in International Law: Current Trends", in K. Miles (ed.), Research Handbook on Environment and Investment Law (Cheltenham: Edward Elgar, 2019), pp. 12-37 [Viñuales 2019]; "Too Many Butterflies? The Micro-Drivers of the International Investment Law System" (2018) 9 Journal of International Dispute Settlement 628 [Viñuales 2018]; "Investor Diligence in Investment Arbitration: Sources and Arguments" (2017) 32 ICSID Review 346 [Viñuales 2017]; "Sovereignty in Foreign Investment Law", in Z. Douglas, J. Pauwelyn, J. E. Viñuales (eds), The Foundations of International Investment Law (Oxford University Press, 2014), pp. 317-62 [Viñuales 2014]; "Customary Law in Investment Regulation" (2013/2014) 23 Italian Yearbook of International Law 23 [Viñuales 2013].

${ }^{20}$ References to the relevant volumes of the ICSID Reports for each decision are provided in bold type in the Appendix.

21 Saluka Investments B.V. v. The Czech Republic, UNCITRAL, Partial Award (17 March 2006) [Saluka v. Czech Republic].

${ }^{22} L G \& E$ Energy Corp, LG\&E Capital Corp, LG\&E International Inc. v. Argentine Republic, ICSID Case No. ARB/02/1, Decision on Liability (3 October 2006) [LG\&E v. Argentina].

${ }^{23}$ CMS Gas Transmission Company v. Argentine Republic, ICSID Case No. ARB/01/08, Decision on Annulment (25 September 2007) [CMS v. Argentina - Annulment]. 
Figure 1 Defence arguments in reported cases

\begin{tabular}{|c|c|c|c|c|c|c|c|c|c|}
\hline $\begin{array}{l}\text { Defence } \\
\text { argument }\end{array}$ & 2007 & 2008 & $2009[\ldots]$ & $2012[\ldots]$ & 2014 & 2015 & 2016 & 2017 & 2018 \\
\hline $\begin{array}{l}\text { Abuse of } \\
\text { right/process }\end{array}$ & & & & & & & \begin{tabular}{|l} 
General \\
Dynamics v. \\
Libya
\end{tabular} & $\begin{array}{l}\text { Orascom } \mathrm{v} . \\
\text { Algeria }\end{array}$ & \\
\hline Acquiescence & & & & & & & & $\begin{array}{l}\text { E energija v. } \\
\text { Latvia }\end{array}$ & \\
\hline $\begin{array}{l}\text { Clean hands } \\
\text { doctrine }\end{array}$ & & & & & Yukos v. Russia & & & $\begin{array}{l}\text { E energija } \mathrm{v} . \\
\text { Latvia }\end{array}$ & $\begin{array}{l}\text { Antaris v. } \\
\text { Czech Rep. }\end{array}$ \\
\hline Contributory fault & & & & & Yukos v. Russia & & & & \\
\hline Corruption & & & & & & & $\begin{array}{l}\text { Churchill } \mathrm{v} . \\
\text { Indonesia }\end{array}$ & $\begin{array}{l}\text { Karkey v. } \\
\text { Pakistan }\end{array}$ & \\
\hline $\begin{array}{l}\text { (Public interest) } \\
\text { Counterclaims }\end{array}$ & & & & & & & $\begin{array}{l}\text { Urbaser } \mathrm{v} . \\
\text { Argentina }\end{array}$ & & \\
\hline Countermeasures & & & $\begin{array}{l}\text { Cargill } \mathrm{v} . \\
\text { Mexico }\end{array}$ & & & & & & \\
\hline $\begin{array}{l}\text { Emergency } \\
\text { clauses (war) }\end{array}$ & $\begin{array}{l}\text { Sempra v. } \\
\text { Argentina }\end{array}$ & \begin{tabular}{|l} 
Continental \\
Casualty $\mathrm{v}$. \\
Argentina
\end{tabular} & & & & & & & \\
\hline Estoppel & & & & & $\begin{array}{l}\text { Bankswitch } \mathrm{v} . \\
\text { Ghana }\end{array}$ & & & $\begin{array}{l}\text { E energija } \mathrm{v} . \\
\text { Latvia }\end{array}$ & \\
\hline $\begin{array}{l}\text { Extinctive } \\
\text { prescription }\end{array}$ & & & & & & & & $\begin{array}{l}\text { E energija v. } \\
\text { Latvia }\end{array}$ & $\begin{array}{l}\text { Mercerv. } \\
\text { Canada }\end{array}$ \\
\hline Force majeure & & & & & & $\begin{array}{l}\text { Von Pezold } \mathrm{v} . \\
\text { Zimbabwe }\end{array}$ & $\begin{array}{l}\text { Devas v. India } \\
\text { General } \\
\text { Dynamics v. } \\
\text { Libya }\end{array}$ & & \\
\hline Illegality & & & & & $\begin{array}{l}\text { Bankswitch } \mathrm{v}, \\
\text { Ghana }\end{array}$ & $\begin{array}{l}\text { Quiborax } \mathrm{v} . \\
\text { Indonesia }\end{array}$ & $\begin{array}{l}\text { Churchill } \mathrm{v} . \\
\text { Indonesia }\end{array}$ & & $\begin{array}{l}\text { Cortec } \mathrm{v} . \\
\text { Kenya }\end{array}$ \\
\hline $\begin{array}{l}\text { Imprévision / } \\
\text { unforeseeability/ } \\
\text { hardship }\end{array}$ & $\begin{array}{l}\text { Semprav. } \\
\text { Argentina }\end{array}$ & & & & & & & & $\begin{array}{l}\text { ENKA v. } \\
\text { Gabon }\end{array}$ \\
\hline $\begin{array}{l}\text { International } \\
\text { public policy }\end{array}$ & & & & & $\begin{array}{l}\text { Bankswitch } \mathrm{v} . \\
\text { Ghana }\end{array}$ & & $\begin{array}{l}\text { Churchill } \mathrm{v} . \\
\text { Indonesia }\end{array}$ & & \\
\hline $\begin{array}{l}\text { Margin of } \\
\text { appreciation }\end{array}$ & & & & & & $\begin{array}{l}\text { Von Pezold } \mathrm{v}, \\
\text { Zimbabwe }\end{array}$ & $\begin{array}{l}\text { Philip Morris } \\
\text { v. Uruguay }\end{array}$ & & \\
\hline Necessity & \begin{tabular}{|l|} 
Sempra v. \\
Argentina
\end{tabular} & $\begin{array}{l}\text { Continental } \\
\text { Casualty v. } \\
\text { Argentina }\end{array}$ & & & & $\begin{array}{l}\text { Von Pezold } \mathrm{v} . \\
\text { Zimbabwe }\end{array}$ & \begin{tabular}{|l|} 
Urbaser $\mathrm{v}$. \\
Argentina \\
Devas $\mathrm{v}$. India
\end{tabular} & & \\
\hline $\begin{array}{l}\text { Non-precluded } \\
\text { measures } \\
\text { protecting } \\
\text { essential security } \\
\text { interests }\end{array}$ & $\begin{array}{l}\text { Sempra v. } \\
\text { Argentina }\end{array}$ & $\begin{array}{l}\text { Continental } \\
\text { Casualty v. } \\
\text { Argentina }\end{array}$ & & & & & Devas v. India & & \\
\hline Police powers & & & & & & $\begin{array}{l}\text { Quiborax v. } \\
\text { Bolivia }\end{array}$ & $\begin{array}{l}\text { Philip Morris } \\
\text { v. Uruguay }\end{array}$ & & \\
\hline $\begin{array}{l}\text { Public } \\
\text { procurement } \\
\text { carve-outs }\end{array}$ & & & & & & & & & $\begin{array}{l}\text { Mercerv. } \\
\text { Canada }\end{array}$ \\
\hline $\begin{array}{l}\text { Reservation of } \\
\text { specifically } \\
\text { identified } \\
\text { measures }\end{array}$ & & & & $\begin{array}{l}\text { Mobil v. } \\
\text { Canada }\end{array}$ & & & & & \\
\hline $\begin{array}{l}\text { Scope of } \\
\text { prohibitions of } \\
\text { local content } \\
\text { requirements }\end{array}$ & & & & $\begin{array}{l}\text { Mobil v. } \\
\text { Canada }\end{array}$ & & & & & \\
\hline $\begin{array}{l}\text { Taxation carve- } \\
\text { outs }\end{array}$ & & & & & Yukos v. Russia & & & & $\begin{array}{l}\text { Antaris v } \\
\text { Czech Rep. }\end{array}$ \\
\hline Wilful blindness & & & & & & & $\begin{array}{l}\text { Churchill } \mathrm{v} . \\
\text { Indonesia }\end{array}$ & & \\
\hline
\end{tabular}


6. While some of the decisions reported in this volume are more than a decade old ${ }^{24}$ the bulk of the volume focuses on more recent decisions, which often provide a summary of the previous body of case law relating to a given defence. For these decisions, the objective is not that of reporting a leading case but that of identifying a "juncture" between a relatively mature body of case law on a given defence and subsequent developments. Two illustrations are Cargill v. Mexico on the issue of countermeasures ${ }^{25}$ and Cortec v. Kenya on the operation of the plea of illegality. ${ }^{26}$ Other reported decisions are, at least in part, foundational or important precedents. Such is the case, for example, of the discussion, in Yukos v. Russia, of the operation of the tax carve-out (Article 21) in the Energy Charter Treaty ${ }^{27}$ and the doctrine of clean hands in international law, ${ }^{28}$ that of the margin of appreciation doctrine in Philip Morris v. Uruguay, ${ }^{29}$ that of public interest State counterclaims in Urbaser v. Argentina ${ }^{30}$ or, still, that of abuse of right in a context of multiple arbitration claims in Orascom v. Algeria. ${ }^{31}$ However, the selection of reported decisions is not an endorsement of their conclusions. Such conclusions are, in some cases, controversial and possibly unrepresentative of the state of international law, as discussed in Part II of this preliminary study.

7. A second dimension relevant for the analysis of defence arguments is their stage of intervention. Some defence arguments, e.g. the illegality of an investment, have a broad span stretching from jurisdiction, over admissibility, to the merits and even quantum. The assessment of such span must be conducted in concreto, i.e. by reference to cases in which a defence argument has been actually used to challenge jurisdiction or admissibility or to defeat an argument on the merits or reduce or exclude damages. Even when such arguments are unsuccessful, recognition by a tribunal that they can operate at a given stage is deemed sufficient to establish their span. Yet, as before, recognition of their span in this manner is, for present purposes, a purely descriptive exercise, and it is not an endorsement of the legal positions followed in the reported decisions. Subject to this caveat, Figure 2 summarises the span of the twenty-three defence arguments covered in the reported decisions.

\footnotetext{
24 See Sempra Energy International v. The Argentine Republic, ICSID Case No. ARB/02/16, Award (28 September 2007) [Sempra v. Argentina]; Continental Casualty Company v. The Argentine Republic, ICSID Case No. ARB/03/9, Award (5 September 2008) [Continental Casualty v. Argentina].

25 Cargill, Incorporated v. United Mexican States, ICSID Case No. ARB(AF)/05/2, Award (18 September 2009) [Cargill v. Mexico], paras. 379-430.

${ }_{26}$ Cortec Mining Kenya Limited, Cortec (Pty) Ltd and Stirling Capital Ltd v. Republic of Kenya, ICSID Case No. ARB/15/29, Award (22 October 2018) [Cortec v. Kenya], paras. 310-87.

27 Yukos Universal Limited (Isle of Man) v. The Russian Federation, PCA Case No. AA 227, Final Award (18 July 2014) [Yukos v. Russia], paras. 1401-47.

28 Yukos v. Russia, paras. 1343-74.

29 Philip Morris Brand Sàrl (Switzerland), Philip Morris Products S.A. (Switzerland) and Abal Hermanos S.A. (Uruguay) v. Oriental Republic of Uruguay, ICSID Case No. ARB/10/7, Award (8 July 2016) [Philip Morris v. Uruguay], paras. 397-420. See also the dissent, paras. 181-91.

30 Urbaser S.A. and Consorcio de Aguas Bilbao Biskaia, Bilbao Biskaia Ur Partzuergoa v. Argentine Republic, Award (8 December 2016) [Urbaser v. Argentina], paras. 1143-55, 1182-1210.

31 Orascom TMT Investments S.à.r.l. v. People's Democratic Republic of Algeria, ICSID Case No. ARB/12/35, Final Award (31 May 2017) [Orascom v. Algeria], paras. 539-48.
} 
Figure 2 Stage of operation of the defence arguments covered

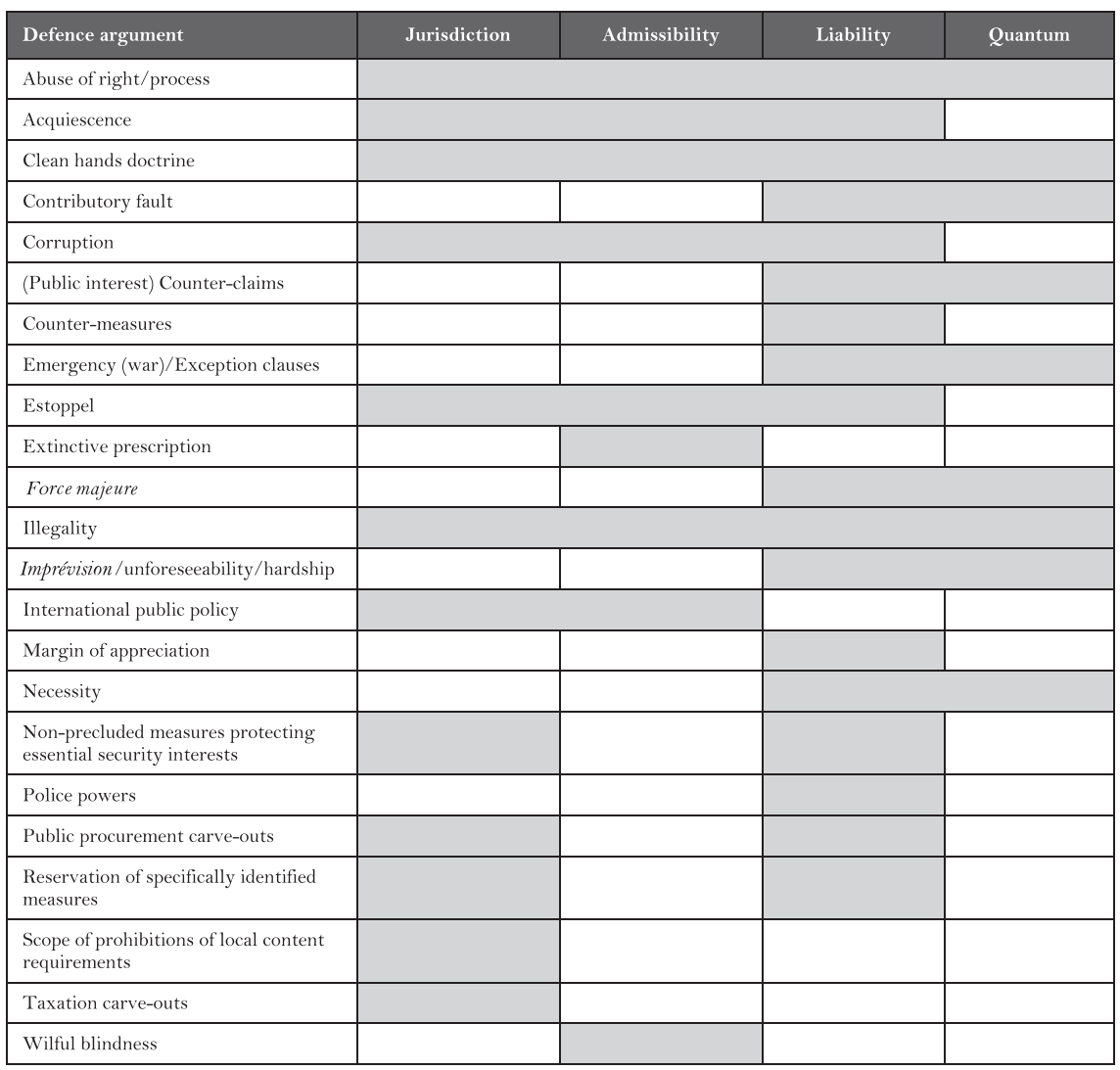

8. A third dimension relevant for this overview concerns the broad dividing line between what can be called "exemptions" (whether the specific term retained in a given treaty or case is that of "carve-out", "safeguard", "derogation" or "non-precluded measure") and "exceptions" (whether "exception" or other terms, such as "emergency" or "war clauses" or "circumstances precluding wrongfulness" or, still, "excuses"). From a technical perspective, the key consideration is whether the defence argument operates at the level of the primary norm of conduct or at that of the secondary norms of State responsibility. This distinction, famously introduced by Roberto Ago to modernise the codification effort of the UN International Law Commission on the complex topic of State responsibility, ${ }^{32}$ is sufficiently established to be relied upon as a legally meaningful dividing line. Exemptions

32 Second report on State responsibility, by Mr. Roberto Ago, Special Rapporteur. The origin of international responsibility, 20 April 1970 [original French text], UN Doc. A/CN.4/233, para. 11 ("[i]n its previous drafts, the Commission has generally concentrated on defining the rules of international law which, in one sector of inter-State relations or another, impose particular obligations on States, and which may, in a certain sense, be termed 'primary', as opposed to other rules - precisely those covering the field of responsibility - which may be termed 'secondary', inasmuch as they are concerned with determining the consequences of failure to fulfil obligations established by the primary rules"). 
Figure 3 Angle of incidence of the defence arguments covered

\begin{tabular}{|c|c|c|c|c|c|}
\hline \multicolumn{3}{|c|}{ Scope of the primary norm } & \multicolumn{3}{|c|}{ Secondary norms } \\
\hline $\begin{array}{l}\text { General scope } \\
\text { of/reliance on the } \\
\text { applicable treaty }\end{array}$ & $\begin{array}{l}\text { Specific scope of } \\
\text { the primary norm }\end{array}$ & $\begin{array}{c}\text { Assessment of } \\
\text { breach of primary } \\
\text { norm }\end{array}$ & Specific excuses & $\begin{array}{c}\text { Generally available } \\
\text { excuses }\end{array}$ & $\begin{array}{l}\text { Quantum } \\
\text { reduction }\end{array}$ \\
\hline $\begin{array}{l}\text { Perimeter of the } \\
\text { treaty: } \\
\text { Illegality } \\
\begin{array}{l}\text { Non-precluded } \\
\text { measures protecting } \\
\text { essential security } \\
\text { interests }\end{array} \\
\text { Taxation carve-outs } \\
\text { Deprivation of } \\
\text { reliance: } \\
\text { Abuse of right } \\
\text { Acquiescence } \\
\text { Corruption } \\
\text { Estoppel } \\
\text { Extinctive } \\
\text { prescription } \\
\text { International public } \\
\text { policy } \\
\text { Wilful blindness }\end{array}$ & 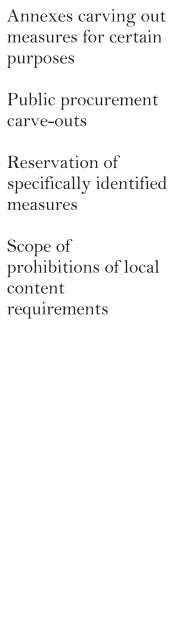 & $\begin{array}{l}\text { (Public interest) } \\
\text { Counterclaims } \\
\text { Margin of } \\
\text { appreciation } \\
\text { Police powers }\end{array}$ & $\begin{array}{l}\text { Emergency clauses } \\
\text { (including war } \\
\text { clauses) } \\
\text { Exceptions }\end{array}$ & $\begin{array}{l}\text { Countermeasures } \\
\text { Force majeure } \\
\text { Imprévision/ } \\
\text { unforeseeability/ } \\
\text { hardship } \\
\text { Necessity }\end{array}$ & $\begin{array}{l}\text { Clean hands } \\
\text { doctrine } \\
\text { Contributory } \\
\text { fault } \\
\text { Duty to mitigate } \\
\text { damages }\end{array}$ \\
\hline
\end{tabular}

generally operate at the level of the primary norm. If a given measure falls under the scope of an exemption (irrespective of the terminology retained), it is not covered by the primary norm and hence the latter cannot be breached. If, instead, a given measure falls under the scope of an exception (again, irrespective of the terminology retained), it both falls under the scope of the primary norm and this norm would be technically breached, with all the resulting consequences, but for the operation of the exception (whether the latter excuses the breach or removes its wrongfulness altogether). In $C M S$ v. Argentina, a distinguished Ad Hoc Committee emphasised this difference, noting that an exemption (in casu Article XI of the Argentina-US BIT) could not operate at the same time as the customary necessity defence precisely because if Article XI applied, there could be no breach capable of being excused by the necessity defence. ${ }^{33}$ A dividing line formulated in terms of "exemptions" and "exceptions" leaves out, however, a range of important defence arguments, such as the police powers and the margin of appreciation doctrines, which cannot easily find a meaningful place in this analytical cartography. Thus, to make the distinction better adapted to a wider range of defence arguments, it is useful to rely on the distinction between arguments that operate at the level of primary and secondary norms, respectively. Figure 3 summarises this vantage point for the full set of defence arguments covered in this study. The location of different defence arguments in Figure 3 reflects their operation in the decisions reported in this volume or discussed in this preliminary study.

33 CMS v. Argentina - Annulment, para. 129. 
9. The implications of formulating - as counsel - or appraising - as arbitrator a defence argument from one or the other side of the dividing line are potentially significant, whether technically or practically. By way of illustration, much is conceded if the police powers doctrine, which is a corollary of State sovereignty, is argued as an "exception" rather than as the "rule". The burden of proof, the stated or implicit level of restrictiveness of interpretation, the scope of scrutiny (or the degree of deference) or the sequence of application may indeed be significantly affected, ${ }^{34}$ as I shall observe in the discussion of specific defence arguments in Part II.

10. Two additional caveats regarding Figure 3 concern its interactions with the vantage point adopted in Figure 2 and the observation, made in the introduction, that in international law the category of "defences" or "affirmative defences" has no technical existence. Regarding the first caveat, the tables are consistent, but they cannot be reduced to one another. For example, whereas the plea of illegality may operate at the stages of jurisdiction, admissibility, merits and quantum, Figure 3 describes it by reference to its operation in the relevant decision reported in this volume, Cortec v. Kenya. This decision illustrates the primary function of the illegality defence, which is to reserve the benefits of a treaty only for lawful investments. Subsequent practice has stretched the operation of this clause well beyond this initial function or, at least, elaborated on how such function is performed for different types of illegality. But, unlike Figure 2, Figure 3 is not intended to depict such developments. As regards the second caveat, the distinction between operation at the level of primary and secondary norms, respectively, does not reintroduce or acknowledge the existence of a technical category of "defences" or "affirmative defences" in international law. The implications of arguing or appraising a defence argument stem from the specific conditions attached to it in international law. Often, such implications, however important, will be of a practical nature. For example, a tribunal may reject the application of a specific standard of proof to establish corruption and, yet, in practice, refuse to be satisfied unless the corruption allegation is very clearly established. Similarly, a tribunal may refuse to recognise that a given clause must be interpreted restrictively and, yet, in practice, conduct a very restrictive interpretation. Practitioners are well aware of such differences, but conceptually it is difficult to chart them in a more general manner. Figure 3 attempts to do so, but it should not be read without keeping in mind this important caveat.

\section{ANALYSIS}

\section{Preliminary Observations}

11. The categories identified in Figure 3 above serve to organise the discussion of the twenty-six defence arguments surveyed in this volume. This survey must be

34 See further Viñuales 2020. 
conducted in the light of both the reported decisions and the wider body of case law, mostly from investment tribunals but also, in some cases, from other international courts and tribunals.

12. In the following paragraphs, I focus on the "trees" but, in order not to lose sight of the "wood", the discussion follows the broad headings of Figure 3, distinguishing between operation at the level of primary and secondary norms, and under each of these headings, between the different subheadings of Figure 3. The latter define a spectrum of defence arguments the operation of which is increasingly circumscribed, from a wider exclusion from the protection of the treaty, over the exclusion from the application of a given clause, to the assessment of breach of an otherwise applicable primary norm, to a specific excuse for an otherwise acknowledged breach, to generally available excuses for breach, to a reduction of the damage awarded.

13. As noted earlier, the location of each defence argument in this spectrum follows their operation in the decisions reported in this volume or discussed in this preliminary study. For each defence argument, particular attention is paid to issues such as (i) the operation of the relevant defence argument in the reported decision(s) as well as in the wider body of relevant case law, (ii) their principal "stage" of operation (jurisdiction, admissibility, merits, quantum) and/or (iii) their technical and/or practical implications (burden and standard of proof, interpretation, deference, and/or application sequence).

\section{Defence Arguments Operating at the Level of the Primary Norm}

\subsection{General Scope of and Reliance on the Applicable Treaty}

\subsubsection{Introduction}

14. The defence arguments organised under this subheading present some common features. One is that they all concern the general question whether a given treaty, specifically a bilateral investment treaty or the investment chapter of a free trade agreement, covers and can be relied upon to protect the investment of a foreign investor against action/inaction from the host State. What is at stake is the scope of and/or reliance on the entire treaty (or the investment chapter thereof) rather than on a specific investment discipline. Such scope/reliance may be excluded either because the action/inaction of the host State is excluded from the overall ambit of application of the treaty, i.e. they are outside the perimeter of the treaty, or because the circumstances are such that granting the protection of the treaty would be inappropriate.

15. Two significant implications can be derived from this basic feature. First, these defence arguments are capable of operating already in relation to the assessment of a tribunal's "jurisdiction" or of the "admissibility" of a claim (or a set of claims). Some of them can also operate at a later stage of the proceedings. Secondly, from a technical and practical perspective, some of these arguments concern the perimeter of the applicable treaty (or instrument), with ensuing consequences for the allocation of the burden of proof and possibly for other aspects such as the approach to interpretation. Conversely, other defence arguments concern the possibility to rely on a treaty (or another legal basis) the perimeter of which normally covers the 
situation at hand. The latter focus has consequences for the allocation of the burden of proof and the setting of the standard of proof.

16. This principled position provides the background against which significant variations in the case law can be analysed. The volatility of the investment case law may at times blur this underlying principle and, in the absence of a clear explanation in the relevant cases, it is necessary to consider more coherent bodies of case law, such as that of the International Court of Justice (ICJ).

\subsubsection{Defence Arguments Concerning the Perimeter of the Treaty}

17. Two main defence arguments concerning the perimeter of the treaty are addressed in the reported decisions. The first relates to the operation of clauses that expressly exclude certain types of measures from the ambit of the treaty. The two main examples from the reported awards are the exclusion of "taxation measures" from the ambit of the Energy Charter Treaty (ECT) ${ }^{35}$ pursuant to its Article 21 and the exclusion of certain measures protecting "essential security interests" under Articles XI of the Argentina-US BIT and 11(3) of the India-Mauritius BIT. ${ }^{36}$

18. The proper role of broad exclusions must not be misunderstood. They are akin to other, more general, ways of defining the ambit of application of an instrument, typically by reference to four dimensions: subject-matter (ratione materiae), personal (ratione personae), temporal (ratione temporis) and spatial (ratione loci). ${ }^{37}$ The norms defining - expressly or implicitly - the perimeter of a treaty thus state the rule, not an exception. One way to recognise them and distinguish them from "excuses" (which operate as exceptions, as discussed later) is their focus on "measures" rather than on "situations". The object excluded from the perimeter of the treaty is a certain type of measure, however it is characterised (including by reference to situations), whereas clauses focusing on "situations" are intended to excuse certain conduct. An investor bringing a claim or a State bringing a counterclaim must establish that the measure it complains about is covered by the treaty. As a matter of principle, raising one of the many defence arguments that can be derived from the definition of the perimeter amounts to emphasising that the treaty is simply not applicable. Provisions such as Articles 21 ECT, XI of the Argentina-US BIT or 11(3) of the India-Mauritius BIT are part of this wider body of norms defining the perimeter of a treaty, and they concern specifically the scope ratione materiae of the relevant treaty. This observation also applies to the second type of defence arguments analysed here, namely, the illegality of the investment whose protection is sought. Yet, given that such illegality can take several forms, with different implications, it must be dealt with separately.

35 Energy Charter Treaty, 17 December 1994, 2080 UNTS 100 [ECT].

36 Both available on the UNCTAD navigator: https://investmentpolicy.unctad.org/international-invest ment-agreements (visited on 27 August 2019).

37 For a detailed discussion of these dimensions of investment treaties see the three chapters by N. Rubins and B. Love on the scope of application ratione temporis, materiae and personae in M. Bungenberg, J. Griebel, S. Hobe, A. Reinisch (eds), Handbook on International Investment Law (Baden-Baden/Oxford: Nomos/Hart, 2015), pp. 481-94, 495-613, 614-52. Application ratione loci can also raise complex issues. See e.g. Sanum Investment Ltd v. The Government of the Lao People's Democratic Republic, Singapore Court of Appeal, [2016] SGCA 57, Judgment (29 September 2016). 


\section{EXCLUSION OF TAXATION MEASURES}

19. The operation of the exclusion of "taxation measures" under Article 21 ECT is addressed in detail in two decisions reported in this volume, Yukos v. Russia ${ }^{38}$ and Antaris v. Czech Republic. ${ }^{39}$ In Antaris, the tribunal observed at the outset that the focus of Article 21 ECT is on "measures" and that when the relevant measure is covered by the scope of the "carve-out", the tribunal has no jurisdiction to hear a claim arising from such measures. ${ }^{40}$ Subsequently, it set out a "two-step analysis" to "ascertain whether a putative tax measure qualifies under Article 21 of the ECT", involving: (i) a characterisation of the measure, and (ii) an application of Article 21's "inherent limits". ${ }^{41}$ The question of the burden and standard of proof arises for each prong of this test separately, and it will be addressed after analysing each of them.

20. On the first prong of the test, the Antaris tribunal focused on the characterisation of the measure as a "taxation measure" under domestic law. It began by noting that Article 21(7) ECT, which defines "Taxation Measures" for the purpose of Article 21, does not contain a "self-standing definition" of such measures but only a reference to either domestic law or applicable international instruments (e.g. double taxation treaties). ${ }^{42}$ It then reviewed the evidence on the record and concluded that the solar levy imposed on renewable energy generators was not a "Taxation Measure" under domestic law. Aside from its fact-specific conclusions, the decision provides guidance for the assessment of the first prong of the test: substance (the nature of the measure) overrides pure form (the designation of the measure as a "tax"); ${ }^{43}$ a tax is normally characterised by its focus, which is to raise revenue for governmental activities, ${ }^{44}$ its non-equivalence, i.e. the fact that the amounts paid are not directly in exchange for a service or some other consideration, ${ }^{45}$ and the general applicability of the measure, rather than the targeting of a specific company or group $;^{46}$ the importance of the characterisation of the measure by domestic courts and the context of such characterisation; ${ }^{47}$ and some additional elements, such as the legislative history of the measure and the purposes stated by the government. ${ }^{48}$

21. Further clarification of the meaning of "taxation measures" can be derived from cases relating to analogous tax carve-outs in other treaties. In EnCana v. Ecuador, the tribunal observed that a taxation measure (for purposes of Article XII(1) of the applicable treaty) is one "imposed by law", and that such is the case if the measure is "sufficiently clearly connected to a taxation law or regulation",

38 Yukos v. Russia, paras. 1401-47.

39 Antaris Solar GmbH and Dr. Michael Göde v. Czech Republic, PCA Case No. 2014-01, Award (2 May 2018) [Antaris v. Czech Republic], paras. 215-53.

40 Antaris v. Czech Republic, para. 217 (concerning a measure - the repeal of an income tax exemption - which the claimants had admitted to be a "taxation measure" for the purpose of Article 21 ECT). It must be noted, however, that the exclusion of jurisdiction does not concern every type of claims. Claims for violation of Article 13 ECT (expropriation) are excluded from the exclusion. The operation of this so-called "claw-back" provision is addressed in Yukos v. Russia, as discussed later.

41 Antaris v. Czech Republic, para. 224. $\quad{ }_{42}$ Antaris v. Czech Republic, para. 221.

43 Antaris v. Czech Republic, para. 229. $\quad 44$ Antaris v. Czech Republic, para. 248.

45 Antaris v. Czech Republic, para. 236. $\quad 46$ Antaris v. Czech Republic, para. 250.

47 Antaris v. Czech Republic, para. 233. $\quad 48$ Antaris v. Czech Republic, para. 243. 
irrespective of its legality under domestic law. ${ }^{49}$ A taxation law was defined as "one which imposes a liability on classes of persons to pay money to the State for public purposes". 50 The tribunal further noted that there is no reason to limit the concept to a certain type of tax or to the provisions of the tax law as such (rather than encompassing related regulations and decisions) and, importantly, that what is determinative is the "legal operation" of the measure, not its "economic effects ... which may be unclear and debatable". ${ }^{51}$ Another relevant decision is Burlington v. Ecuador. ${ }^{52}$ In this case, the tribunal relied on EnCana as well as on Duke v. Ecuador ${ }^{53}$ to characterise a tax as involving four elements: "(i) there is a law (ii) that imposes a liability on classes of persons (iii) to pay money to the State (iv) for public purposes". 54 These decisions all suggest that taxation measures can be characterised by reference to an objective core content.

22. The Antaris tribunal reached a similar conclusion - albeit following a different path - when characterising the second prong of the test. It noted that, although Article 21 ECT did not provide an "express international definition of tax measures to which the provision applies", 55 the tribunal was "persuaded that Article 21 was not intended to encompass measures which had principal objectives other than the raising of revenue, but rather to exempt measures which formed part of a Contracting Party's general tax regime, aimed principally at raising revenue". 56 Thus, the tribunal introduced some objective meaning into the definition of taxation measures in Article 21, which constitutes an "inherent limit" to the ability of States to rely on the referral to domestic law made in Article 21(7)(a)(i) ECT. However, the second prong of the test also encompasses another type of limitation on the use of Article 21 ECT, which concerns not its scope but its invocation. The possibility of relying on Article 21 for measures adopted "under the guise" of taxation powers played a decisive role in a stream of decisions concerning the actions of Russia against Yukos and its shareholders.

23. The analysis of Article 21 ECT in Yukos v. Russia sheds light on the limits of both the perimeter and the invocation of this provision. Regarding the perimeter, the tribunal discussed the so-called "claw-back" of Article 21(5)(a) according to which "Article 13 [expropriation] shall apply to taxes." This provision carves out claims for expropriation from the scope of the carve-out relating to taxation measures. Thus, Article 21(5)(a) is to Article 21 what Article 21 is to the ECT. The main issue in dispute was the wording used in Article 21(5)(a), which refers to "taxes" and not to "Taxation Measures" (as Article 21(1)). The tribunal rejected the interpretation proposed by the respondent, which considered taxes as a narrow subcategory of taxation measures, and sided with the claimant noting that "[i]n the

49 EnCana Corporation v. Republic of Ecuador, LCIA Case No. UN3481, UNCITRAL Rules, Award (3 February 2006) [EnCana v. Ecuador], para. 142(1).

50 EnCana v. Ecuador, para. 142(4). ${ }_{51}$ EnCana v. Ecuador, para. 143(3)-(4).

52 Burlington Resources v. Ecuador, ICSID Case ARB/08/5, Decision on Jurisdiction (2 June 2010) [Burlington v. Ecuador].

53 Duke Energy Electroquil Partners \& Electroquil S.A. v. Republic of Ecuador, ICSID Case No. ARB/04/19, Award (18 August 2008).

${ }_{54}$ Burlington v. Ecuador, para. 165. $\quad{ }^{55}$ Antaris v. Czech Republic, para. 247.

56 Antaris v. Czech Republic, para. 248. 
view of the Tribunal, the ordinary meaning of 'tax' used in Article 21(5) cannot be narrower than the meaning of 'Taxation Measure' used in Article 21(1)". 57 This interpretation is reasonable, and it seems consistent with Article 21(5)(b), which assumes that Article 13 remains fully operative in connection with taxes, but it does not explain why two different words were used in the same provision. Of note is the fact that the other claw-backs in Article 21 (i.e. paragraphs (2), (3) and (4)), all use the term "Taxation Measures". The use of an undefined term such as "taxes" rather than a defined term, "Taxation Measures", must therefore have an effet utile. The respondent's understanding of "taxes" may have been too narrow, but it does capture that "taxes", however narrowly or broadly understood, are a subcategory of taxation measures. As for the relations between Article 13 and Article 21, paragraph (5)(b) of the latter subjects claims against allegedly expropriatory and/or discriminatory taxes to a preliminary procedure (a referral to tax authorities) akin to the exhaustion of local remedies. The relations between this procedure and investment arbitration tribunals under Article 26 ECT are explicitly addressed in letters (i), (iii) and (iv) of Article 21(5)(b). The Yukos tribunal emphasised that, much like in other contexts where the exhaustion of local remedies is required, such procedures do not affect the admissibility of a claim when they are futile. ${ }^{58}$ This conclusion makes clear that the referral is not a matter of perimeter (jurisdiction) but of invocation of Article 21 (admissibility).

24. The Yukos decision also sheds light on the operation of Article 21 ECT with respect to taxation measures adopted in bad faith. After recalling the factual conclusions that it had reached through a review of the entire record, ${ }^{59}$ the tribunal reasoned that the "Article 21 carve-out does not apply to the Russian Federation's measures because they are not ... on the whole, a bona fide exercise of the Russian Federation's tax powers." 60 Instead, the tribunal saw the measures at stake as measures "under the guise of taxation, but in reality aim[ed] to achieve an entirely unrelated purpose". 61 While this conclusion may fit the specific circumstances of the case, it conflates two distinct levels, namely that of good/ bad faith in adopting the measures and that of good/bad faith in relying on Article 21 . The analysis moves directly from one level to the other. The explanation provided to deprive Russia of the possibility of relying on Article 21 is reasonable, i.e. the risk that the mere "labelling" of a measure as "taxation" may place it outside the scope of the ECT. But such a risk could be addressed through other means: for example, a focus on substance rather than form, as in the approach followed by the Antaris tribunal, or an assessment based on a core characterisation of taxation measures, as in EnCana v. Ecuador. By contrast, limiting the scope of Article 21 only to bona fide taxation measures brings into the definition of taxation a subjective and fact-intensive dimension (measures may have more than one motivation and such motivation may be difficult to establish). The issue raised some controversy in an analogous context, namely the definition of investment. Some decisions brought good faith as part of the very definition of

57 Yukos v. Russia, para. 1413.

59 Yukos v. Russia, para. 1404.

61 Yukos v. Russia, para. 1431.
58 Yukos v. Russia, paras. 1421-6.
60 Yukos v. Russia, para. 1403. 
investment, ${ }^{62}$ with the implication that only investments made in good faith would be protected. The alternative is that the definition of investment does not require an element of good faith, but bad faith or an abuse of right may, under certain circumstances (e.g. a restructuring after the dispute becomes foreseeable) preclude reliance on the treaty. ${ }^{63}$ In the specific context of Article 21 ECT, the approach followed in the Yukos case may have the effect, at a minimum, of turning a technical legal question into a much more fact-intensive and volatile one, and possibly to extend the legal application of a treaty such as the ECT to measures which are excluded from it. ${ }^{64}$ Thus, whereas the end result of the Yukos decision may be reasonable, the path selected is not without problems.

25. A further issue that must be addressed concerns the burden and the standard of proof. As a general matter, the tribunal has the competence to examine its own jurisdiction, if necessary ex officio, and the scope of Article 21 is not a factual matter but a legal one. The tribunal is therefore tasked with conducting this legal inquiry and reaching a conclusion. However, this apparently legal question can be deeply affected by factual considerations, such as the determination of whether the respondent abused its taxation powers to pursue motives unrelated to genuine taxation. These factual elements require an allocation of the burden of proving the relevant facts and the identification of the applicable standard of proof. Two main inquiries must be distinguished. First, on the allocation of the burden of proving the facts underlying the taxation carve-out, the two prongs of the test raise different issues. The decisions reviewed lack clarity on the allocation of the burden of establishing whether a measure is a taxation measure. ${ }^{65}$ As a matter of principle, the burden of proving that the treaty is applicable to the measure challenged is on

62 Phoenix Action, Ltd v. The Czech Republic, ICSID Case No. ARB/06/5, Award (15 April 2009) [Phoenix v. Czech Republic], paras. 100-13; Gustav F W Hamester GmbH \& Co. KG v. Republic of Ghana, ICSID Case No. ARB/07/24, Award (18 June 2010) [Hamester v. Ghana], paras. 123-4. See also Saba Fakes v. Republic of Turkey, ICSID Case No. ARB/07/20, Award (14 July 2010) [Saba Fakes v. Turkey], paras. 104-14 (criticising the reference to good faith and legality as components of the definition of investment).

63 See Philip Morris Asia Limited v. The Commonwealth of Australia, UNCITRAL, PCA Case No. 2012-12, Award on Jurisdiction and Admissibility (17 December 2015) [Philip Morris v. Australia], para. 554 (although the tribunal dissociated the allegation of abuse of right/process from a finding of bad faith).

64 The Yukos tribunal disregarded this possibility in its assessment of the EnCana precedent, possibly due to the assurances from the Claimant's expert, who had presided over the EnCana tribunal (Yukos v. Russia, paras. 1440-2). Without questioning that solution in the facts of Yukos, the fact remains that in EnCana, the tribunal expressly noted that even if the respondent had applied taxation rules "in an 'idiosyncratic' manner, this does not lead to the conclusion that its conduct falls outside the scope of the exclusion for taxation measures. The demands were made by authorised tax officials in purported compliance with the relevant law; they were subject to review by the tax courts and eventually by the Taxation Chamber of the Supreme Court. They bear all the marks of a taxation measure - whether a lawful one under Ecuadorian law it is not for the Tribunal to decide", EnCana v. Ecuador, para. 146.

65 In Duke v. Ecuador, the tribunal assumed that the claimant must establish the applicability of the treaty (Duke v. Ecuador, paras. 176-7, 184). In Burlington v. Ecuador, the tribunal confined itself to observe that "at the jurisdictional stage, it must be established that the conditions to jurisdiction set ... in the BIT are met" (Burlington v. Ecuador, para. 110). By contrast, in Antaris v. Czech Republic, the tribunal seemed to assume that the State relying on the tax carve-out has the burden of characterising the measure as a "Taxation Measure" (Antaris v. Czech Republic, para. 225). 
the party making such allegation, i.e. the claimant, ${ }^{66}$ or exceptionally the respondent in the context of a counterclaim. The ambiguity comes from different possible readings of the maxim onus probandi incumbit actori. If the allegation to be proved is that the treaty is applicable, the onus would fall on the claimant. If the allegation to be proved is that the treaty is not applicable, the onus would fall on the respondent. When both allegations are made, as in virtually all cases, the solution will result from two main considerations. On the one hand, there is no presumption of/constructive applicability of a treaty, so any failure in establishing such applicability will eventually be borne by the party relying on the treaty. ${ }^{67} \mathrm{On}$ the other hand, for clauses excluding specific types of "measures", the respondent can be expected to establish prima facie that the measure in question qualifies as an excluded measure, and then the burden will shift to the claimant to establish that such is not the case. This was the approach followed in Eiser v. Spain in connection with Article 21 ECT, where the tribunal noted that the respondent had established the "characteristics typically associated with a legitimate tax" and then shifted, implicitly, the burden to the claimant to establish that this preliminary showing should be disregarded. ${ }^{68}$ The same logic applies to establishing the availability of a claw-back: the claimant would have to establish prima facie that the measure falls under this "exclusion from the exclusion" and then the burden will shift to the respondent. ${ }^{69}$ By contrast, the burden of proving the "futility" of the tax referral procedure and, above all, bad faith in either the adoption of the measure or the reliance on the carve-out is clearly on the claimant. ${ }^{70}$ With respect to the standard of proof applicable to "bad faith", as in other similar allegations, it must be higher than the ordinary standard, however defined, although tribunals rarely specify it. $^{71}$

66 See Philip Morris v. Australia, para. 495; Apotex Inc. v. United States, UNCITRAL Rules, Award on Jurisdiction and Admissibility (14 June 2013) [Apotex v. United States], para. 150; Mesa Power Group, LLC v. Government of Canada, UNCITRAL, PCA Case No. 2012-17, Award (24 March 2016) [Mesa v. Canada], para. 236 ("It is for the Claimant to establish the factual elements necessary to sustain the Tribunal's jurisdiction over the challenged measures").

${ }^{67}$ See Case relating to the Territorial Jurisdiction of the International Commission of the River Oder, Judgment (10 September 1929), P.C.I.J. Series A No. 23, pp. 18-22 (where the PCIJ concluded that failure to timely raise the non-applicability of a treaty - due to lack of ratification - did not make the treaty applicable).

68 Eiser Infrastructure Limited and Energía Solar Luxembourg S.à.r.l. v. Kingdom of Spain, ICSID Case No. ARB/13/36, Final Award (4 May 2017) [Eiser v. Spain], paras. 266-72. See also Philip Morris v. Australia, para. 495. This is also the approach followed by the WTO Appellate Body in India - Additional Duties, paras. 185-95 (in connection with Article II:2(a) of the GATT).

69 Burlington v. Ecuador, paras. 231-49.

70 There is authority for the proposition that tax measures are presumed to be bona fide. See Tza Yap Shum v. Peru, ICSID Case No. ARB/07/6, Award (7 July 2011) [Tza Yap Shum v. Peru], para. 125; El Paso Energy International Co. v. Argentine Republic, ICSID Case No. ARB/03/15, Award (31 October 2011) [El Paso v. Argentina], para. 290; Renta 4 S.V.S.A et al. v. Russian Federation, SCC Case No. 24/2007, Award (20 July 2012) [Renta 4 v. Russia], para. 181; Eiser v. Spain, para. 271.

${ }^{71}$ EnCana v. Ecuador, para. 146 (noting that even if the application of tax law were found to be inconsistent, that would not be enough to disregard the carve-out); Yukos v. Russia, para. 1407 (referring to the "extraordinary circumstances of this case") and 1404 (summarising the factual conclusions reached by the tribunal on the basis of the entire evidentiary record); Antaris v. Czech Republic, para. 253 (expressly noting that its finding on the first prong of the test does not imply bad faith from the government); Eiser v. Spain, para. 275 (stating that inferences would not be enough). 


\section{NON-PRECLUDED MEASURES PROTECTING ESSENTIAL SECURITY INTERESTS}

26. Regarding non-precluded measures adopted, inter alia, for the protection of "essential security interests", the reported decisions address two main examples, namely Article XI of the Argentina-US BIT, which is discussed in Sempra v. Argentina ${ }^{72}$ and Continental Casualty v. Argentina, ${ }^{73}$ and Article 11(3) of the India-Mauritius BIT, discussed in Devas v. India. ${ }^{74}$ These three cases illustrate the wide range of sometimes inconsistent views, which investment tribunals more generally have expressed regarding the operation of such clauses.

27. Sempra and Continental Casualty offer two contrasting views of the operation of Article XI of the Argentina-US BIT. In Sempra, the tribunal followed the steps of the tribunals in $C M S$ v. Argentina ${ }^{75}$ and Enron v. Argentina, ${ }^{76}$ to treat Article XI as an emergency clause operating alongside - and subject to the same conditions as - the customary necessity defence. ${ }^{77}$ As noted in Part I of this study, this conflation of two concepts which operate at separate stages was severely criticised by the Ad Hoc Committee in CMS v. Argentina, and the misapplication of Article XI led to the annulment of the Sempra and Enron awards on this specific point. ${ }^{78}$ The award in Continental Casualty, which followed the decision of the Ad Hoc Committee in $C M S$, was also subject to an application for annulment. The claimant argued that the tribunal, in applying Article XI had disregarded an alternative claim, namely that even if Article XI applied to the measures in question, the respondent "must still compensate the Investor and cease its actions in breach of the Treaty because any threat to Argentina's essential security interests or public order has passed" 79 The Committee rejected the application for annulment in its entirety, but this allegation is a useful entry point to clarify the operation of clauses such as Article XI of the Argentina-US BIT.

28. The starting point of the analysis is that such clauses generally focus on "measures" and not on "situations". A focus on the "situation" may render the above allegation of the investor before the Ad Hoc Committee in Continental Casualty relevant. As discussed later in this study, if a clause "excuses" certain conduct in the light of the situation, then the excuse can only last as long as the situation lasts. Yet, Article XI focuses on "measures". It states that:

72 Sempra v. Argentina, paras. 325-97. $\quad 73$ Continental Casualty v. Argentina, paras. 160-236.

74 CC/Devas (Mauritius) Ltd., Devas Employees Mauritius Private Limited and Telcom Devas Mauritius Limited v. Republic of India, PCA Case No. 2013-09, Award on Jurisdiction and Merits (25 July 2016) [Devas v. India], paras. 211-95.

75 CMS Gas Transmission Company v. The Republic of Argentina, ICSID Case No. ARB/01/8, Award (12 May 2005) [CMS v. Argentina - Award]

76 Enron Corporation and Ponderosa Assets, L.P. v. Argentine Republic, ICSID Case No. ARB/01/3, Award (22 May 2007) [Enron v. Argentina - Award].

77 Sempra v. Argentina, para. 346.

78 Sempra Energy International v. The Argentine Republic, ICSID Case No. ARB/02/16, Decision on the Argentine Republic's Application for the Annulment of the Award (29 June 2010) [Sempra v. Argentina - Annulment], para. 159; Enron Corporation and Ponderosa Assets, L.P. v. Argentine Republic, ICSID Case No. ARB/01/3, Decision on the Application for Annulment of the Argentine Republic (30 July 2010) [Enron v. Argentina - Annulment], para. 405.

79 Continental Casualty Company v. The Argentine Republic, ICSID Case No. ARB/03/9, Decision on the Application for Partial Annulment of Continental Casualty Company and the Application for Partial Annulment of the Argentine Republic (16 September 2011) [Continental Casualty v. Argentina Annulment] para. 111. 
This Treaty shall not preclude the application by either Party of measures necessary for the maintenance of public order, the fulfillment of its obligations with respect to the maintenance or restoration of international peace or security, or the Protection of its own essential security interests. (Emphasis added.)

The Ad Hoc Committee in CMS had emphasised that Article XI was a "threshold requirement: if it applies, the substantive obligations under the Treaty do not apply". ${ }^{80}$ The tribunal in Continental Casualty followed this understanding when noting that: " $[\mathrm{t}]$ he consequence would be that, under Art. XI, such measures would lie outside the scope of the Treaty so that the party taking it would not be in breach of the relevant BIT provision". 81

29. This conclusion would normally entail, as discussed in the context of Article 21 ECT, that the tribunal has no jurisdiction over any claims resulting from the adoption of such non-precluded measures. The Continental Casualty tribunal gave, however, a different effect to such clauses, namely to exclude responsibility for breach of the investment disciplines invoked by the claimant. This is a counterintuitive conclusion, which may be explained by a combination of relative novelty (of the arguments relating to such clauses), inadvertence (in the way the respondent pleaded its case both at the jurisdictional level - omitting Article XI - and on the merits), and possibly a peculiar interpretation of the effects of the clause, which according to the tribunal "restricts or derogates from the substantial obligations undertaken by the parties to the BIT" 82 and revolves around the seriousness of the crisis addressed through the relevant measures. ${ }^{83}$ Another tribunal, applying a different type of "non-precluded measures" clause (Article 10.10 of the Oman-US FTA) ${ }^{84}$ reached an analogous conclusion, namely that such clause was to be relied upon at the merits stage for the interpretation of the fair and equitable treatment clause. ${ }^{85}$ This is likely due to the specific formulation of the clause ("[n]othing in this Chapter shall be construed to prevent") which emphasises matters of interpretation. Figure 2 above records these conclusions by signalling that clauses carving out non-precluded measures operate at the merits level according to some tribunals. Yet, as a matter of principle, the proper operation of non-precluded measures clauses should be at the jurisdictional level because the clause is a general exclusion from the perimeter of the entire treaty (" $t]$ his Treaty shall not preclude ..."). What matters is whether the measures in question fall under the scope of the clause, in which case they are simply outside the treaty and any claim resulting from their adoption is beyond the jurisdiction of the tribunal.

30. An important question that has arisen in practice is whether the qualification of the measures is unilateral, i.e. "self-judging". The question is analogous to that

\footnotetext{
80 CMS v. Argentina - Annulment, para. 129. $\quad{ }^{81}$ Continental Casualty v. Argentina, para. 164.

82 Continental Casualty v. Argentina, paras. 164 and 167.

83 Continental Casualty v. Argentina, para. 182 (focusing on the situation rather than on the measures). 84 Article 10.10 of the Oman-US FTA provides that "[n]othing in this Chapter shall be construed to prevent a Party from adopting, maintaining, or enforcing any measure otherwise consistent with this Chapter that it considers appropriate to ensure that investment activity in its territory is undertaken in a manner sensitive to environmental concerns".

85 Adel A Hamadi Al Tamimi v. Sultanate of Oman, ICSID Case No. ARB/11/33, Award (3 November 2015) [Al Tamimi v. Oman], para. 387.
} 
regarding the qualification of measures as "taxation" for the purpose of a tax carveout. If the discretion of the State is unfettered, that may pave the way for abuse. In Continental Casualty, the tribunal relied on the case law of the $\mathrm{ICJ}^{86}$ to conclude that the determination by a State can be subsequently reviewed by a tribunal, although the State will "naturally" benefit from a "margin of appreciation". ${ }^{87}$ This conclusion is sound and reflects a settled position in the case law. ${ }^{88}$

31. It is possible that out of the set of measures challenged, some may fall under the clause and some others may not. In Continental Casualty, the tribunal concluded that the restructuring of certain treasury bills did not fall under Article XI because its specific timing and terms did not make them necessary to protect essential security interests. ${ }^{89}$ The conformity of such measure with the applicable treaty (specifically the fair and equitable treatment clause) was subsequently assessed and the measure found in breach of this standard. ${ }^{90}$ It is also possible that the same measure may be in part sufficiently related to the protection of essential security interests and in part not. This situation arose in Devas v. India. The main issue was whether a measure (the reservation of a certain frequency of the electro-magnetic spectrum, the S-band, previously allocated to the claimants) was covered by Article 11(3) of the India-Mauritius BIT, according to which:

The provisions of this Agreement shall not in any way limit the right of either Contracting Party to apply prohibitions or restrictions of any kind or take any other action which is directed to the protection of its essential security interests, or to the protection of public health or the prevention of diseases in pests or animals or plants.

On the evidence, a majority of the tribunal concluded that, to the extent that the reservation of the spectrum served the needs of the defence and military forces, it fell under the clause. But the measure was also aimed to reserve the spectrum for "railways and other public utility services as well as for other societal needs" and, to this extent, it was not "directed to the protection of [the respondent's] essential security interests". 91 The part of the spectrum reserved for such other uses (which the majority of the tribunal estimated at 40 per cent) was not excluded from the perimeter of the treaty by the operation of Article 11(3), and it therefore fell under the relevant investment disciplines (in casu Article 6 on expropriation). ${ }^{92}$ Importantly, for the 60 per cent part that fell under Article 11(3), the majority of the tribunal concluded that it lacked jurisdiction. ${ }^{93}$

86 Military and Paramilitary Activities in and against Nicaragua (Nicaragua v. United States of America), Jurisdiction and Admissibility, Judgment, I.C.J. Reports 1984, p. 392, para. 282; Military and Paramilitary Activities in and against Nicaragua (Nicaragua v. United States of America), Merits, Judgment, I.C.J. Reports 1986, p. 14 [Nicaragua-Merits], para. 222; Oil Platforms (Islamic Republic of Iran v. United States of America), Judgment, I.C.J. Reports 2003, p. 16 [Oil Platforms], para. 43.

87 Continental Casualty v. Argentina, para. 187.

$88 C M S$ v. Argentina - Award, paras. 359 and 370; LG\&E v. Argentina, paras. 212-13; Enron v. Argentina - Award, para. 339; El Paso v. Argentina, para. 561; Devas v. India, paras. 219, 235, 244 and 353.

89 Continental Casualty v. Argentina, paras. 220-1.

90 Continental Casualty v. Argentina, paras. 264-6, 304. 91 Devas v. India, para. 354.

92 Devas v. India, para. 371. One of the arbitrators dissented, but his dissent focused on the factual assessment underlying the majority's finding. Specifically, he considered that there had been no factual allocation of spectrum and, as a result, that Article 11(3) could not be relied upon.

93 Devas v. India, para. 501(c). 
32. In addition to the applicable requirements and the effects, the proper framing of clauses on non-precluded measures is also relevant for the allocation of the burden of proof and the approach to interpretation. On the first issue, the observations made earlier in connection with taxation carve-outs apply generally. There is an important nuance, however, arising from the specific wording of each clause. Whereas establishing that a given measure is a "taxation measure" may be straightforward at a prima facie level, thus shifting the burden to the claimant, the same may not be true of measures which are defined by their relation to a situation of crisis ("public order") or the pursuance of a specific goal (protection of "essential security interests"). If the respondent were to bear the full - rather than the prima facie - burden of proof, the operation of a general exclusion clause would, in practice, be equated with that of specific or general excuses. In other words, the claimant's burden to establish that the treaty is applicable to its claims would not only be greatly facilitated, it would for most purposes be replaced with a presumption that the treaty applies. At the same time, a claimant cannot reasonably be expected to bear the full burden of proving that there was no crisis or that the measures are not sufficiently linked to the protection of essential security interests. To find an appropriate balance between these considerations, the respondent must establish prima facie that the clause is available, and a margin of appreciation must be granted to its determination of what measures are sufficiently linked to public order or to the protection of essential security interests. Once that prima facie showing is made, the burden shifts to the claimant. The decision in Devas v. India is significant in this regard because it made this point explicit:

An arbitral tribunal may not sit in judgment on national security matters as on any other factual dispute arising between an investor and a State. National security issues relate to the existential core of a State. An investor who wishes to challenge a State decision in that respect faces a heavy burden of proof, such as bad faith, absence of authority or application to measures that do not relate to essential security interests. ${ }^{94}$

The second issue to be noted is the approach to interpretation. Although tribunals routinely refer to the rules of treaty interpretation of the Vienna Convention on the Law of Treaties, ${ }^{95}$ the framing of a non-precluded measures clause may affect the level of stringency applied, technically or practically, in the assessment of the availability of a clause. In Continental Casualty, the tribunal observed that the margin of appreciation accorded to States in determining how to pursue these overriding goals is also relevant for interpretation purposes, ${ }^{96}$ and it excluded the restrictive interpretation proposed by the claimant. Conversely, as will be discussed later in connection with the necessity defence (a generally available excuse), other tribunals have followed, in practice, a much more restrictive approach to interpretation based on a conflation of clauses reserving nonprecluded measures and excuses.

94 Devas v. India, para. 245 (emphasis added).

95 Vienna Convention on the Law of Treaties, 23 May 1969, 1155 UNTS 331 [VCLT].

96 Continental Casualty v. Argentina, para. 181. 


\section{ILLEGALITY OF THE INVESTMENT}

33. Illegality of the investment as a defence argument can result from a specific provision in the applicable treaty (e.g. in the definition of "investment" or the delimitation of what investments are "protected") 97 or from the implicit understanding that illegal investments do not deserve protection. ${ }^{98}$ The operation of this argument is illustrated in three reported decisions, Bankswitch v. Ghana, ${ }^{99}$ Churchill v. Indonesia, ${ }^{100}$ and Cortec v. Kenya, ${ }^{101}$ though from different vantage points. To understand their contribution, it is useful to place them in the broader context of the case law addressing pleas of illegality. ${ }^{102}$

34. As a general matter, pleas of illegality can operate at the jurisdictional, admissibility, liability and quantum stages, although the arguments vary across them. One significant distinction in the case law is that between "initial" and "subsequent" illegality. ${ }^{103}$ Initial illegality concerns investments which were illegally "made", and it may exclude jurisdiction ${ }^{104}$ or make the claim inadmissible. ${ }^{105}$ Subsequent illegality arises when the violation of domestic law results from the activities of the investment scheme after it was made. Such illegality is relevant for the assessment of the merits ${ }^{106}$ and possibly also for the reduction of

97 See A. Joubin-Bret, "Admission and Establishment in the Context of Investment Protection" in A. Reinisch (ed.), Standards of Investment Protection (Oxford University Press, 2008), pp. 9-28; A. de Mestral, "Pre-Entry Obligations under International Law", in M. Bungenberg, J. Griebel, S. Hobe, A. Reinisch (eds), Handbook on International Investment Law (Baden-Baden/Oxford: Nomos/Hart, 2015), pp. 685-99.

98 See e.g. Plama Consortium Limited v. Bulgaria, ICSID Case No. ARB/03/24, Award (27 August 2008) [Plama v. Bulgaria], 138-9; Phoenix v. Czech Republic, para. 101; Cortec v. Kenya, para. 333(a) ("The text and purpose of the BIT and the ICSID Convention are not consistent with holding host governments financially responsible for investments created in defiance of their laws fundamental [to] protecting public interests such as the environment. The explicit language to the effect that protected investments must be made 'in accordance with the laws of Kenya' is therefore unnecessary to secure the objects and purpose of the BIT").

99 Bankswitch Ghana Ltd v. The Republic of Ghana, UNCITRAL, Award (11 April 2014) [Bankswitch v. Ghana], paras. 11.23-11.34.

${ }^{100}$ Churchill Mining PLC and Planet Mining Pty Ltd v. Republic of Indonesia, ICSID Case Nos. ARB/ 12/14 and 12/40, Award (6 December 2016) [Churchill v. Indonesia], paras. 487-532.

101 Cortec v. Kenya, paras. 310-87. 102 This section relies on Viñuales 2017.

103 See Fraport AG Frankfurt Airport Services Worldwide v. Republic of the Philippines, ICSID Case No. ARB/03/25, Award (16 August 2007) [Fraport v. The Philippines], para. 345; Bernhard von Pezold and others v. Republic of Zimbabwe, ICSID Case No. ARB/10/15, Award (28 July 2015) [Von Pezold v. Zimbabwe], para. 420; Hulley Enterprises Limited (Cyprus) v. The Russian Federation, UNCITRAL, PCA Case No. AA 226, Final Award (18 July 2014) [Hulley v. Russia], paras. 1354-6; Yukos v. Russia, paras. 1354-6; Veteran Petroleum Limited (Cyprus) v. The Russian Federation, UNCITRAL, PCA Case No. AA 228, Final Award (18 July 2014) [Veteran Petroleum v. Russia], para. 1354-6; Copper Mesa Mining Corporation v. Republic of Ecuador, UNCITRAL, PCA No. 2012-2, Award (15 March 2016) [Copper Mesa v. Ecuador], para. $5.54 \mathrm{ff}$; Rusoro Mining Ltd v. Bolivarian Republic of Venezuela, ICSID Case No. ARB(AF)/12/5, Award (22 August 2016) [Rusoro v. Venezuela], para. 289ff.

104 See e.g. Inceysa Vallisoletana S.L. v. Republic of El Salvador, ICSID Case No. ARB/03/26, Award (2 August 2006) [Inceysa v. El Salvador], paras. 242, 248 and 339(2); Europe Cement Investment and Trade S.A. v. Republic of Turkey, ICSID Case No. ARB(AF)/07/2, Award (13 August 2009) [Europe Cement v. Turkey], para. 180; Alasdair Ross Anderson et al. v. Costa Rica, ICSID Case No ARB(AF)/07/3, Award (19 May 2010) [Anderson v. Costa Rica], paras. 26, 55 and 59; Cortec v. Kenya, para. 333.

105 See e.g. Plama v. Bulgaria, paras. 135, 139 and 146; Churchill v. Indonesia, paras. 507-8, 528-9; Bankswitch v. Ghana, paras. 11.75-11.97.

106 See e.g. Malicorp Limited v. Arab Republic of Egypt, ICSID Case No. ARB/08/18, Award (7 February 2011) [Malicorp v. Egypt], paras. 116, 130, 136-7; David Minnotte and Robert Lewis 
quantum. ${ }^{107}$ Given the implications of this distinction, it is important to determine what exactly may amount to "initial" illegality. This, in turn, raises three questions, namely: (i) the identification of the relevant domestic laws, (ii) the nature of the violation of domestic law, and (iii) the extent to which it can be relied upon for different purposes.

35. Over time, investment tribunals have tended to expand the scope of the laws relevant for the assessment of the illegality. A line can be drawn from some early cases such as Inceysa v. El Salvador, where the initial illegality is defined by some fundamental norms such as the prohibition of corruption, ${ }^{108}$ over cases such as Saba Fakes v. Turkey, which define narrowly the domestic laws relevant for the determination of initial illegality, ${ }^{109}$ to decisions such as Mamidoil v. Albania ${ }^{110}$ or Cortec v. Kenya, ${ }^{111}$ where the relevant laws are broadly understood. Mamidoil and Cortec are also significant for the understanding of other aspects of pleas of illegality.

36. The dispute in Mamidoil concerned allegations of mistreatment of a Greek investor in connection with the construction and operation of an oil container terminal as well as petrol stations in Albania. The respondent argued, among others, that the investment had not been made in accordance with the host States' domestic laws because the claimant had failed to conduct a due diligence assessment or seek the relevant (construction, environmental and exploitation) permits. The tribunal found that the lack of construction and exploitation permits amounted to a non-trivial illegality, but it nevertheless asserted jurisdiction on the - debatable - grounds that the respondent's behaviour had cured the initial illegality. Its reasoning can be summarised in four points. First, the tribunal adhered to the well-established distinction between initial and subsequent illegality. ${ }^{112}$ Secondly, and importantly, it noted that illegality can arise out of inconsistency with substantive and/or procedural domestic law, and it understood both bodies of law broadly. ${ }^{113}$ Thirdly, not any violation of domestic law was deemed capable of

v. Republic of Poland, ICSID Case No. ARB(AF)/10/1, Award (16 May 2014) [Minnotte v. Poland], paras. 131-9.

107 See e.g. Southern Pacific Properties (Middle East) Limited (SPP) v. Arab Republic of Egypt, ICSID Case No. ARB/84/3, Award (20 May 1992) [SPP v. Egypt], paras. 191, 250.

108 Inceysa v. El Salvador, paras. 257, 264. For a recent iteration of this approach see ECE Projektmanagement International GmbH and Kommanditgesellschaft PANTA Achtundsechzigste Grundstücksgesellschaft mbH \& Co. v. Czech Republic, PCA Case No. 2010-5, Award (19 September 2013) [ECE v. Czech Republic], paras. 3.170-3.171.

109 Saba Fakes v. Turkey, para. 119 (according to the tribunal, only the illegality arising from a violation of the host State's law relating to the admission of investments would exclude jurisdiction). For a recent iteration of this approach see Metal-Tech Ltd v. Republic of Uzbekistan, ICSID Case No. ARB/10/3, Award (4 October 2013) [Metal-Tech v. Uzbekistan], para. 165.

110 Mamidoil Jetoil Greek Petroleum Products Societe Anonyme S.A. v. Republic of Albania, ICSID Case No. ARB/11/24, Award (30 March 2015) [Mamidoil v. Albania], paras. 372, 378.

111 Cortec v. Kenya, paras. 345-7. ${ }^{112}$ Mamidoil v. Albania, para. 359.

113 On the scope of the relevant substantive law, the tribunal stated the following: "[t]he Tribunal finds that an investment can be illegal and as a consequence not protected by investment conventions when it contravenes substantive law, in other words when it does not comply with material norms regulating investments. Norms may prohibit certain business activities, such as the production of drugs, or they may reserve certain sectors to national entities or protect certain sectorial or geographical areas, for example, by making an investment in a national park illegal" (Mamidoil v. Albania, para. 372). On the 
excluding jurisdiction. Only material breaches of domestic law, not minor irregularities have this effect. Fourthly, the tribunal admitted the possibility that initial illegality may not defeat jurisdiction when the respondent has forgone the possibility to invoke it (e.g. because the deficiency was cured domestically or on the basis of estoppel) or when the State has stood ready to remedy the illegality. ${ }^{114}$

37. In Cortec v. Kenya, the dispute concerned the protection of "a mining license [SML 351] not issued 'in accord with the laws of Kenya' because the Claimants failed to satisfy statutory prerequisites such as EIA [environmental impact assessment] approval". ${ }^{115}$ The tribunal concluded, in essence, that "for an investment such as a license, which is the creature of the laws of the Host State, to qualify for protection, it must be made in accordance with the laws of the Host State". 116 The particular type of "investment", which unlike land, buildings or equipment, had no existence except under and in conformity with domestic law led the tribunal to conclude that there was, indeed, no investment capable of protection, hence that it had no jurisdiction. ${ }^{117}$ But its reasoning with regard to the determination of illegality is relevant for any investment, particularly for the identification of the relevant domestic laws and of the nature of the inconsistency with them. On the first point, the tribunal took into consideration the entire Kenyan legal system to determine the lawfulness of the investment, but particularly three separate but similarly relevant statutes - the Mining Act, the Forests Act, and the Antiquities and Monuments Act - as well as the Environmental (Impact Assessment and Audit) Regulations. It concluded that, as a result of their combined application, the issuance of a mining licence to conduct operations in a protected area (the Mrima Hill nature reserve) was void $a b$ initio. This is an important statement which emphasises that the relevant laws are not a narrow category (e.g. the domestic investment law) but the entire domestic legal system. At the same time, not every inconsistency with this system is capable of making an investment illegal. On this second point, the Cortec tribunal relied on a proportionality criterion borrowed from Kim v. Uzbekistan. ${ }^{118}$ In Kim, the tribunal had retained the following test for a plea of illegality:

the Tribunal holds that the legality requirement in the BIT denies the protections of the BIT to claims when the investment involved was made in noncompliance with a law of [the

scope of the relevant procedural law, the tribunal noted that "The second source of possible illegality concerns procedural rules. In the Tribunal's view, an investment can be found illegal for procedural reasons when the investor does not respect the norms regulating the process of investment. The investment may be legal in substance but still tainted by illegality when the investor violates procedural norms and regulations for setting up its investment" (Mamidoil v. Albania, para. 378). It then went on to analyse consistency with construction, environmental and operation requirements. Although the scope of the relevant laws was challenged by the investor-appointed arbitrator in a dissenting opinion (see Dissenting Opinion of Steven A. Hammond, 30 March 2015, paras. 128-31), the majority's stance should be preferred both on the facts of the case and as a general principle.

114 Mamidoil v. Albania, paras. 490-5. ${ }^{115}$ Cortec v. Kenya, para. 313.

116 Cortec v. Kenya, para. 319.117 Cortec v. Kenya, para. 343.

118 Vladislav Kim and others v. Republic of Uzbekistan, ICSID Case No. ARB/13/6, Decision on Jurisdiction (8 March 2017) [Kim v. Uzbekistan], para. 413. 
host State] where together the act of noncompliance and the content of the legal obligation results in a compromise of a correspondingly significant interest of [the host State]. ${ }^{119}$

The Cortec tribunal reformulated this test as stating that "for an investment to be protected on the international level, it has to be in substantial compliance with the significant legal requirement of the host state". ${ }^{120}$ It noted, like the tribunal in Mamidoil, that omission of a minor regulatory requirement or inadvertent misstatements cannot have the same effect as "defiance of an important statutory prohibition imposed in the public interest". ${ }^{121}$ Relying again on Kim, the tribunal followed three steps in its determination of the nature of the violation, focusing tour à tour on: (i) the significance of the obligation violated, (ii) the seriousness of the investor's conduct, and (iii) whether denial of protection under the BIT is proportionate with the violation, given the extent to which the host State's interests are compromised. ${ }^{122}$

38. Significantly, it is not a requirement for the violation to be sanctioned with nullity in the domestic legal system, as long as proportionality is maintained. Illegalities that make a legal act voidable (annullable) rather than void (null) could be considered non-trivial, as suggested by the Mamidoil decision. Moreover, even when the degree of inconsistency is deemed not to require a denial of protection (at the jurisdictional or admissibility stages), the illegal conduct of the claimant can still be taken into account at the liability and quantum stages, much like subsequent illegality. Furthermore, it is possible that a subsequent illegality may be relied upon to challenge the admissibility of the claim. ${ }^{123}$ In addition, it is also possible that an initial non-trivial illegality may be subsequently cured, as was the case in Mamidoil, or that the host State may be estopped from relying on such illegality. The latter case can be illustrated by Bankswitch v. Ghana. The dispute concerned the performance of a contract for the provision of an internet portal for Ghana's customs operations. The arbitration proceedings were brought under the dispute settlement clause of the contract, which was subject to Ghana's law. As part of its defence, the government argued that the contract was invalid because it had not received the parliamentary approval required by Article 181(5) of Ghana's Constitution. The tribunal decided that Article 181(5) was indeed applicable, and that the validity of the contract was therefore subject to such approval; yet, it also found that the government, by reason of its conduct, was estopped from now claiming that such approval procedure had not been completed. Subsequently, it reviewed the claim on the merits and found that the respondent had breached the contract. This case will be discussed again in connection with estoppel but, for present purposes, together with Mamidoil v. Albania, it illustrates that even an initial illegality of sufficient importance may be inoperative. This limitation is itself subject to an overriding limitation, namely that illegality reaching a certain threshold of seriousness, such as corruption, wilful blindness and inconsistency

\footnotetext{
119 Kim v. Uzbekistan, para. 404. ${ }^{120}$ Cortec v. Kenya, para. 321.

121 Cortec v. Kenya, para. 320. 122 Cortec v. Kenya, para. 343-65.

123 Such was the case in Awdi v. Romania, although the objection was rejected. Hassan Awdi, Enterprise Business Consultants, Inc. and Alfa El Corporation v. Romania, ICSID Case No. ARB/ 10/13, Award (2 March 2015) [Awdi v. Romania], paras. 206-13.
} 
with international public policy, cannot be cured or dismissed. This is discussed in the context of each one of these three specific defence arguments.

39. The allocation of the burden of proof for pleas of illegality is, as for other defence arguments, seldom fleshed out in the decisions of investment tribunals. Setting a clear line in this matter is difficult because pleas of illegality can operate at several stages of the proceedings and, depending on the specific context, the allocation may not be the same. Framed through the lenses of jurisdiction, as discussed earlier in this study, it is the tribunal which has to satisfy itself that it has the requisite jurisdiction over the claims submitted to it, but there may be factual questions associated with such a determination (e.g. the significance of the obligation violated, the seriousness of the investors' conduct, and the impact on the host State's interest) that require evidence and hence raise the allocation question. In Kim v. Uzbekistan, the tribunal expressly allocated this burden to the respondent:

Before the Tribunal begins its application of the legality test to the violations alleged in this objection, the Tribunal observes that Respondent has the burden of proof to establish that the investment was not made in compliance with a law of Uzbekistan. ${ }^{124}$

In Cortec, the claimant requested the tribunal to allocate the burden to the respondent $^{125}$ and, although the tribunal did not take an explicit stance on this question, it endorsed the approach of the tribunal in $\mathrm{Kim},{ }^{126}$ which implicitly endorsed such allocation. This seems justified because, unlike other defence arguments focusing on jurisdiction, illegality claims are based on an allegation of wrongdoing by the investor, which is for the respondent to establish. This is a fortiori the case when illegality is framed from the perspective of admissibility, as the allegation concerns wrongdoing of a magnitude that would require a tribunal not to exercise an adjudicative power that it possesses. ${ }^{127}$

\subsubsection{Defence Arguments Concerning the Entitlement to Rely on the Treaty}

40. Deprivation of reliance involves some form of inappropriate behaviour from the party bringing the claim or making the argument. Bad faith is not always required, ${ }^{128}$ but there must be some degree of negligence or disingenuous behaviour, which in most cases must be established by the party relying on these defence arguments. Two broad sets of arguments can be identified within this subheading. The first set includes estoppel, acquiescence and extinctive prescription, as they have been argued in the investment arbitration context. When the conditions for these defence arguments are met, the party bringing the claim is prevented from relying on the applicable treaty or on another legal basis (e.g. a constitutional provision). The rationale underpinning these arguments is the lack of due diligence displayed by that party or the display of contradictory behaviour. By contrast, the second set of arguments are based on the existence of intent or wilful behaviour,

\footnotetext{
124 Kim v. Uzbekistan, para. 417. ${ }_{125}$ Cortec v. Kenya, para. 315.

126 Cortec v. Kenya, para. 343. 127 See e.g. Awdi v. Romania, para. 212.

128 See e.g. Philip Morris v. Australia, para. 539 (noting that "it is equally accepted that the notion of abuse does not imply a showing of bad faith").
} 
whether when making the investment, corruption or wilful blindness, or when bringing the claim or exercising a right, abuse of right.

41. Defence arguments based on inconsistency of a claim (or of the underlying transaction) with international public policy (ordre public international) can be placed somewhere between these two sets of arguments. International public policy protects a set of core values presumptively recognised as overriding in all domestic legal orders. This makes the concept a composite one in that tribunals have included as part of international public policy concepts such as estoppel alongside other concepts such as corruption, fraud and wilful blindness. Moreover, depending on the framing of this defence argument, it may affect jurisdiction (there is no transaction) or admissibility (the transaction exists but the claim is inadmissible). Thus, it could also be seen as a form of aggravated illegality. In the next paragraphs, international public policy is first discussed in general, as a broad introductory defence argument which can deprive a claimant from relying on the applicable agreement. Subsequently, I focus on the defence arguments that do not require bad faith and, finally, on those that do require it. This discussion includes concepts linked to international public policy.

\section{INTERNATIONAL PUBLIC POLICY ${ }^{129}$}

42. Among the reported decisions, Bankswitch v. Ghana ${ }^{130}$ and Churchill $\mathrm{v}$. Indonesia ${ }^{131}$ touch upon the operation of international public policy (ordre public international), although only on specific issues which will be discussed later. As noted earlier, international public policy generally refers to a narrow core of principles of fundamental importance to a wide number of legal orders - hence presumed to be fundamental to every legal order - which override any inconsistent instrument, agreement or claim. ${ }^{132}$ It is a complex concept because of (i) its origins, i.e. it arises from a constructive generalisation of the core values of domestic legal orders (which at a different epoch were called "civilised" or "advanced"); (ii) its composite content, which includes several other principles which may operate on a stand-alone basis (e.g. corruption, ${ }^{133}$ fraud, ${ }^{134}$ wilful blindness, ${ }^{135}$ and estoppel ${ }^{136}$ ); (iii) its overriding effects, which may void a

\footnotetext{
129 This section relies on Viñuales 2017.

131 Churchill v. Indonesia, paras. 493-4.

132 See Pierre Lalive, "Ordre public transnational (ou réellement international) et arbitrage international" (1986) 3 Revue de l'arbitrage 329. An English translation of this study appeared as Pierre Lalive, "Transnational (or Truly International) Public Policy and International Arbitration", in ICCA Congress Series 1987 No. 3, 257.

133 Karkey Karadeniz Elektrik Uretim A.S. v. Islamic Republic of Pakistan, ICSID Case No. ARB/13/ 1, Award (22 August 2017) [Karkey v. Pakistan], paras. 490-543. See the section of this study on corruption.

134 Inceysa v. El Salvador, para. 246; Europe Cement v. Turkey, para. 180; Renee Rose Levy and Gremcitel SA v. Republic of Peru, ICSID Case ARB/11/17, Award (9 January 2015) [Gremcitel v. Peru], paras. 194-5; Churchill v. Indonesia, para. 493.

135 Plama v. Bulgaria, para. 146; Churchill v. Indonesia, paras. 504-32.

136 Bankswitch v. Ghana, para. 11.72.
} 
transaction of its legal existence (defeating jurisdiction) or make a claim unenforceable (defeating admissibility); and (iv) its logic, which due to the composite content of the concept, varies according with the principle (it may involve deliberate wrongdoing or inconsistency with a higher value, which cannot be overridden transactionally, e.g. protection of human rights).

43. An important precedent clarifying the operation of this concept is World Duty Free v. Kenya, ${ }^{137}$ where the investor sought to enforce a contract obtained by means of a bribe paid to the then Kenyan president. The agreement referred, in its arbitration and choice-of-law clauses, to English and Kenyan law. The tribunal dismissed the claim under both international law (relying on the concept of ordre public international or international public policy) and domestic English and Kenyan law. It noted that bribery was a criminal offence under the applicable Kenyan laws and that contracts obtained by bribery were deemed unenforceable in the common law authorities relevant to the case. Interestingly, the investor sought to mitigate the consequences of its illegal act by highlighting the illegal conduct of the Kenyan president, and it asked the tribunal to achieve a balance between both. However, the tribunal firmly dismissed this argument noting that, even if there had been a rule allowing such exercise of equitable judgement, its use would have been of no help to the claimant. The apparent unfairness of letting Kenya benefit from the illegal act of its president missed the point that the public policy concepts applicable in this case were intended to protect the public as well as to deprive any claimant (including Kenya, had it been the claimant in the case) from relying on a court of law to enforce an act executed against basic public policy principles. ${ }^{138}$

44. A corollary of this conclusion is the impossibility of curing a violation of international public policy, as in Mamidoil v. Albania, or of foregoing reliance on it by reason of estoppel, as in Bankswitch v. Ghana. The latter presents additional complexity because the principle of estoppel has been recognised as part of international public policy. ${ }^{139}$ It may thus be theoretically possible, admittedly in very rare circumstances, for a party to be estopped from invoking estoppel (under the international public policy defence). In the more extreme case of corruption or other grave infringements of the principles protected by international public policy, the reasoning to deny any possibility of curing the wrongdoing would therefore stem from either the inexistence of the transaction, as in Cortec v. Kenya, or the need to ensure "the rule of law, which entails that a court or tribunal cannot grant assistance to a party that has engaged in a corrupt act". ${ }^{140}$ The second justification has implications that the first does not. Indeed, it does not matter whether the inconsistency with international public policy is "initial" or

\footnotetext{
137 World Duty Free Company Limited v. Republic of Kenya, ICSID Case No. ARB/00/7, Award (4 October 2006) [World Duty Free v. Kenya].

138 World Duty Free v. Kenya, paras. 176-8. See also Metal-Tech v. Uzbekistan, para. 389.

139 Bankswitch v. Ghana, para. 11.72 (noting that "Apart from public international law, international public policy as applied consistently in international arbitration ... has to be considered by this Tribunal. Among these principles of international public policy is one closely related to estoppel: inconsistency between a party's claims or defences, and its previous conduct in connection therewith leads to the preclusion of a State from relying on inconsistent positions in a later arbitration, based on the principle of allegans contraria non audiendus est").

140 Metal-Tech v. Uzbekistan, para. 389.
} 
"subsequent", as in the context of illegality. It is the very nature of the inconsistency, whenever it occurs, which commands the denial of any protection.

45. The burden of proving an allegation of misconduct serious enough to be inconsistent with international public policy is with the party alleging such misconduct, normally the respondent. ${ }^{141}$ The seriousness of the allegation is also relevant for the standard of proof. Sufficiently persuasive evidence is necessary, although tribunals have formulated this need through two different approaches. Some tribunals have considered that the "standard of proof" was a more demanding one, such as "clear and convincing evidence". ${ }^{142}$ The issue of the applicable standard of proof is not as clearly regulated in international law as it is in domestic law. The characterisation of the standard is therefore less decisive than the actual, including practical, requirements that a tribunal may expect for a serious allegation to be established. Thus, some other tribunals have focused not on the standard to be applied but on the persuasiveness of the evidence, which they have addressed through the lens of the ordinary standard (balance of probabilities or intime conviction). ${ }^{143}$ The difference between these two approaches is one of form, not of substance. The demands placed on the party who has the burden of proof are similar. $^{144}$

ESTOPPEL

46. Estoppel is addressed in two different contexts in the reported decisions, E energija v. Latvia and Bankswitch v. Ghana. In E energija v. Latvia, the respondent argued that there was no "dispute" under Article 25(1) of the ICSID Convention because the claimant had allegedly induced the respondent to rely on the matter being pursued through negotiations (estoppel) or that, by participating in a meeting allegedly premised on the idea that the investment dispute was "closed", it had acquiesced to this conclusion or, still, that, by submitting its request for arbitration almost four years after its notice of intent, it had forgone its right of action as a result of extinctive prescription. The tribunal rejected the three arguments because the respondent, who was allocated the burden of proof, ${ }^{145}$ had failed to establish the facts underlying the conditions for the application of these three defence arguments. The tribunal admitted that estoppel, acquiescence and extinctive prescription may deprive a tribunal of its "jurisdiction" due to an absence of "dispute", a requirement of Article 25(1) of the ICSID Convention.

141 Churchill v. Indonesia, para. 238; Metal-Tech v. Uzbekistan, para. 237.

142 Himpurna California Energy Ltd (Bermuda) v. PT (Pesero) Perrusahaan Listruik Negara (Indonesia), UNCITRAL Rules, Award (4 May 1999) [Himpurna case], para. 116; Waguih Elie George Siag and Clorinda Vecchi v. Arab Republic of Egypt, ICSID Case No. ARB/05/15, Award (1 June 2009) [Siag v. Egypt], para. 326; EDF (Services) Ltd v. Romania, ICSID Case No. ARB/05/13, Award (8 October 2009) [EDF v. Romania], para. 221.

143 See e.g. Churchill v. Indonesia, para. 244; Libananco Holdings Co. Limited v. Republic of Turkey, ICSID Case No. ARB/06/7, Award (2 September 2011) [Libananco v. Turkey], para. 125.

144 Karkey v. Pakistan, paras. 492-3.

145 UAB E energija (Lithuania) v. Republic of Latvia, ICSID Case No. ARB/12/33, Award, 22 December 2017 [E energija v. Latvia], paras. 533 (on estoppel), 536 (on acquiescence), and 538 (on extinctive prescription). 
47. Despite its brief and somewhat embryonic reasoning, the decision in E energija v. Latvia is a useful reminder of the operation of these defence arguments in an investment context. On estoppel, it recalls, relying on Pope \& Talbot v. Canada, ${ }^{146}$ the three requirements for establishing this defence argument:

(i) "a statement of fact which is clear and unambiguous"; (ii) a statement that "must be voluntary, unconditional and authorised"; and (iii) that "there must be reliance in good faith upon the statement either to the detriment of the party so relying on the statement or to the advantage of the party making the statement". ${ }^{147}$

These requirements are consistent with those identified by the tribunal in Bankswitch v. Ghana, ${ }^{148}$ although in the context of a different allegation, namely that Ghana was estopped from claiming the invalidity of an agreement concluded with the claimant and which Ghana had treated as valid for some time. ${ }^{149}$ The authorities on which the "elements" of estoppel (which in Bankswitch are deemed to be four) are identified also overlap significantly with those in E energija v. Latvia. ${ }^{150}$ This characterisation is also broadly equivalent to that provided by the ICJ in the Land, Island and Maritime Frontier Dispute (El Salvador/Honduras) ${ }^{151}$ and confirmed in Obligation to Negotiate Access to the Pacific Ocean (Bolivia v. Chile). ${ }^{152}$

48. The ICJ's characterisation does not refer explicitly to the second requirement above (voluntary, unconditional and authorised statement). As the ICJ's views on the state of general international law command authority, either the second condition is not an established requirement under general international law or it is implicit in the ICJ's characterisation. The latter is suggested by an observation made by the Court in Obligation to Negotiate, by reference to a previous case, ${ }^{153}$ according to which the statement (condition (i)) must be "consistently made" and the message conveyed must be "fully clear". ${ }^{154}$ A similar conclusion can be reached by reference to the earlier ICJ judgment in the North

\footnotetext{
146 Pope \& Talbot v. Canada - Interim Award, para. 111 (relying on D. Bowett, "Estoppel before International Tribunals and Its Relation to Acquiescence" (1957) 33 British Yearbook International Law 175, at 202)

147 E energija v. Latvia, para. 531. 148 Bankswitch v. Ghana, para. 11.81.

149 Two applications of estoppel in a similar context include Fraport v. The Philippines, para. 346; $A D C$ Affiliate Ltd and ADC \& ADMC Management Ltd v. Republic of Hungary, ICSID Case No. ARB/ 03/16, Award (2 October 2006) [ADC v. Hungary], para. 475.

150 In Bankswitch v. Ghana, para. 11.81), the earliest authority referred to by the tribunal is Bowett 1957, much like in Pope \& Talbot v. Canada, Interim Award, para. 111, which was the basis relied upon by E energija v. Latvia, para. 60. Of note, in Bankswitch v. Ghana, the tribunal also referred to North Sea Continental Shelf, Judgment, I.C.J. Reports 1969, p. 3 [North Sea Continental Shelf], para. 30.

${ }_{151}$ Land, Island and Maritime Frontier Dispute (El Salvador/Honduras), Application to Intervene, Judgment, I.C.J. Reports 1990, p. 118, para. 63 (describing the "essential elements" of estoppel as "a statement or representation made by one party to another and reliance upon it by that other party to his detriment or to the advantage of the party making it").

152 Obligation to Negotiate Access to the Pacific Ocean (Bolivia v. Chile), Judgment of 1st October 2018, I.C.J. General List No. 153 [Obligation to Negotiate], para. 158.

153 Land and Maritime Boundary between Cameroon and Nigeria (Cameroon v. Nigeria), Preliminary Objections, Judgment, I.C.J. Reports 1998, p. 303 [Cameroon v. Nigeria], para. 57.

154 Obligation to Negotiate, para. 158.
} 
Sea Continental Shelf case (referring to "past conduct, declarations, etc., which ... clearly and consistently evinced acceptance" 155 of the position protected by estoppel) and the more recent Chagos Island Arbitration, where the arbitral tribunal identified, as a requirement for estoppel, that the relevant representation must be "made through an agent authorized to speak for the State with respect to the matter in question". 156

49. The Obligation to Negotiate case confirms that the burden is on the party alleging the estoppel argument to establish the facts underlying its conditions. It illustrates the operation of estoppel on the merits of the case (in casu, whether estoppel provided a basis for Chile to be bound by an obligation to negotiate with Bolivia an access to the Pacific Ocean), and it addresses the operation of acquiescence.

\section{ACQUIESCENCE}

50. For present purposes, the Obligation to Negotiate case discussed earlier is also a useful reference on acquiescence, given the very concise treatment of this argument in E energija v. Latvia. There, the tribunal found that, despite almost four years between the notice of intent and the request for arbitration, the conduct of the claimant did not amount to acquiescence to the extinction of its claims. ${ }^{157}$ It did not provide a clear characterisation of the requirements of acquiescence, and none can be derived from the decision on which the respondent had based its argument. ${ }^{158} \mathrm{By}$ contrast, in Obligation to Negotiate, the ICJ recalled the meaning of acquiescence in general international law as a "tacit recognition manifested by unilateral conduct which the other party may interpret as consent", ${ }^{159}$ based on the idea that "silence may also speak, but only if the conduct of the other State calls for a response". 160

51. As noted in connection with estoppel, the burden of proving that silence must be interpreted as consent is on the party alleging acquiescence. ${ }^{161}$ In Obligation to Negotiate, acquiescence was relied on as a possible basis for the existence of an obligation to negotiate, which the Court rejected. This is a reminder that acquiescence can operate beyond matters of jurisdiction or admissibility, and it has actually played a significant role in territorial disputes. ${ }^{162}$

\footnotetext{
155 North Sea Continental Shelf, para. 30.

156 Chagos Marine Protected Area (Republic of Mauritius v. United Kingdom), PCA, Award (18 March 2015) [Chagos Island Arbitration], para. 438.

157 E energija v. Latvia, para. 538.

158 M.C.I. Power Group L.C. and New Turbine Inc. v. Republic of Ecuador, ICSID Case No. ARB/03/
} 6, Award (31 July 2007) [MCI v. Ecuador]. In this case, acquiescence arose in the context of domestic proceedings in Ecuador, which were discontinued on the alleged grounds that the legal representative of the investor had acquiesced to it. The tribunal considered that the reasoning of the domestic court in question was flawed, for a legal representative who, as the court had concluded, had no longer a valid mandate could not acquiesce on behalf of the investor (see paras. 338, 344-6).

159 Obligation to Negotiate, para. 152, quoting from Delimitation of the Maritime Boundary in the Gulf of Maine Area (Canada/United States of America), Judgment, I.C.J. Reports 1984, p. 305, para. 130.

160 Obligation to Negotiate, para. 152, quoting from Sovereignty over Pedra Branca/Pulau Batu Puteh, Middle Rocks and South Ledge (Malaysia/Singapore), Judgment, I.C.J. Reports 2008, p. 51, para. 121.

161 Obligation to Negotiate, para. 152; E energija v. Latvia, para. 536.

162 See e.g. Temple of Preah Vihear (Cambodia v. Thailand), Judgment, I.C.J. Reports 1962, p. 6, at 30-1; Sovereignty over Pulau Ligitan and Pulau Sipadan (Indonesia/Malaysia), Judgment, I.C.J. Reports 2002, p. 625, paras. 120-2. 


\section{EXTINCTIVE PRESCRIPTION}

52. Extinctive prescription is not clearly disentangled, in the reasoning of the tribunal in E energija v. Latvia, from acquiescence, perhaps due to the facts of the case. The tribunal concluded that, in the absence of a specific provision in the applicable treaty barring claims brought beyond a certain period of time, the claimant was free to choose the moment of filing of its arbitration request. The tribunal added that the period of almost four years between the notice of intent and the request of arbitration was "insufficient to attract the application of the doctrine of prescriptive extinction", ${ }^{163}$ without explaining this doctrine further.

53. The operation of the doctrine of extinctive prescription (prescription liber atoire) in international law has been widely - albeit not unanimously ${ }^{164}$ - recognised as a general principle of law in the meaning of Article 38(1)(c) of the ICJ Statute. ${ }^{165}$ It is based on considerations of equity and fairness due to the respondent, ${ }^{166}$ much like the "affirmative defence" found in Anglo-American systems (doctrine of laches) with roots in Roman law. ${ }^{167}$ As a result, in the absence of a treaty-defined period within which an international claim must be brought, the doctrine leaves significant discretion to the adjudicator. ${ }^{168}$ The requirements that must be established are not consistently defined. Three of them are recurrent in discussions of extinctive prescription and can be considered as its core, namely: (i) an unreasonable delay ${ }^{169}$ in the presentation ${ }^{170}$ of the claim without a valid justification; ${ }^{171}$ (ii) the delay must have placed the respondent at a disadvantage in defending itself; ${ }^{172}$ and (iii) the invocation of the extinctive prescription by the

163 E energija v. Latvia, para. 539.

164 See e.g. Pious Fund Case (United States of America v. Mexico) (1902) IX RIAA 11, at 13; Alsop Case (United States of America v. Chile) (1911) XI RIAA 355, at 370.

165 A detailed and authoritative survey of early practice and opinion on this matter can be found in the report by N. Politis and Ch. De Visscher, "La prescription libératoire en droit international public", included in the Annuaire de l'Institut de Droit International, 1925, vol. 1925 (Hague Session), part 1 (preparatory works). The nature of the norm as a general principle of law is noted in Article I of the IDI Resolution, "La prescription libératoire en droit international public", Hague Session, 31 July 1925 [IDI Resolution]. Earlier discussions of authorities and precedents in an adjudication setting are given in the Williams Case (1890) 4 Moore International Arbitrations 4181 [Williams case] and the Gentini Case (Italy v. Venezuela) (1903) X RIAA 551 [Gentini case], which eventually retained and applied this rule. For a more recent discussion (other than E energija v. Latvia) see Grand River Enterprises Six Nations Ltd et al. v. United States of America, UNCITRAL, Decision on Objections to Jurisdiction (20 July 2006) [Grand River v. United States], paras. 33-8.

166 Williams case; IDI Resolution, Article I.

167 See A. R. Ibrahim, "The Doctrine of Laches in International Law" (1997) 83 Virginia Law Review 647.

168 IDI Resolution, Article II.

169 As this defence argument rests on equity, the specific period of time is not specifically set in general international law, and it depends on the circumstances of the case. See Gentini case, at 561; IDI Resolution, Article II.

${ }^{170}$ Some authorities distinguish between presentation and subsequent prosecution of the claim, see Carlos Butterfield \& Co. Case (1898) 2 Moore International Arbitrations 1184, at 1185-6. In contemporary terminology, this is analogous to a "notice of intent" and an actual "request of arbitration". However, what seems to be decisive is the absence of negligence. Presentation signals diligence, but subsequent negligence in actually formulating the claim may nevertheless be held against the claimant. See IDI Resolution, Article III(2).

171 Williams case, at 4193-4; IDI Resolution, Article III(2).

172 Gentini case, at 560 ("Great lapse of time is known to produce certain inevitable results, among which are the destruction or the obscuration of evidence by which the equality of the parties is disturbed 
respondent. ${ }^{173}$ Other requirements concern the nature of the underlying obligation $^{174}$ or the availability of a sufficient factual record to the respondent, ${ }^{175}$ but they can both be seen as extensions of either the reasonableness of the delay (e.g. a State may withhold an action to assert a territorial claim for over a century) or potential disadvantage of the respondent (which is limited if the latter keeps a factual record).

54. The allocation of the burden of proof for extinctive prescription is less settled than for estoppel and acquiescence. In E energija v. Latvia, the tribunal implied that the burden was on the respondent, but the relevant paragraph ${ }^{176}$ is ambiguous and could also be interpreted as placing the burden on the claimant (with the respondent failing to "rebut" the claimant's argument). A claimant must establish that its action is timely, i.e. brought within the specified deadline to do so ${ }^{177}$ yet, the respondent is required to raise this objection or it is forgone. The allocation of the burden of proof thus finds support in two different rationales, which however point in opposite directions.

55. The case relied upon in E energija v. Latvia on this issue, namely Grand River v. United States, is of limited help. It focused on a treaty-defined three-year limitation period (under Articles 1116(2) and 1117(2) of the NAFTA) and, disappointingly, it expressly refused to take a position on the question of the burden of proof. ${ }^{178}$ In practice, it placed it on the respondent. ${ }^{179}$ Similarly, in Mercer v. Canada, the tribunal did not take a clear stance on the allocation of the burden of proof, although it seemed to place it on the respondent for the issue of constructive knowledge. ${ }^{180}$

56. The approach in these two cases is inconsistent with that of other investment tribunals. The tribunal in Philip Morris v. Uruguay noted in relation to the allocation of the burden of proving the exhaustion of local remedies that "this is a condition that has to be satisfied prior to asserting a denial of justice claim. It is for the Claimants to show that this condition has been met or that no remedy was

or destroyed, and as a consequence renders the accomplishment of exact or even approximate justice impossible").

${ }_{173}$ IDI Resolution, Article V. ${ }^{174}$ IDI Resolution, Article III(1).

175 Giacopini Case (Italy v. Venezuela) (1903) X RIAA 594, at 595; Tagliaferro Case (Italy v. Venezuela) (1903) X RIAA 592, at 592.

${ }^{176}$ E energija v. Latvia, para. 538 ("The Respondent did not rebut the Claimant's reply that the BIT contained no time limits ... Similarly, the Respondent did not rebut the Claimant's contention that prescriptive extinction had been applied in cases in which the respondent had been put at a disadvantage by the lapse of time and that the Respondent had shown no disadvantage in the present case."

177 As noted by a tribunal deciding an objection arising from a limitation period set in Article 10.18.1: "If the Claimants cannot establish, to an objective standard, that they first acquired knowledge of the breaches and losses that they allege in the period after 10 June 2010, they fall at the first hurdle. To surmount this obstacle, each claimant must show, in respect of each property claim, that they have a cause of action, a distinct and legally significant event that is capable of founding a claim in its own right, of which they first became aware in the period after 10 June 2010", Aaron C. Berkowitz, Brett E. Berkowitz and Trevor B. Berkowitz (formerly Spence International Investments and others) v. Republic of Costa Rica, ICSID Case No. UNCT/13/2, Interim Award on Jurisdiction (25 October 2016) [Spence v. Costa Rica], para. 163.

${ }_{178}$ Grand River v. United States, para. 37. $\quad{ }^{179}$ Grand River v. United States, para. 57.

180 Mercer International Inc. v. Government of Canada, ICSID Case No. ARB(AF)/12/3, Award (8 March 2018) [Mercer v. Canada], para. 6.23. 
available giving 'an effective and sufficient means or redress' or that, if available, it was 'obviously futile'." 181 Although the exhaustion of local remedies is distinct from the timeliness of the action, it provides a useful indication of how the allocation should be made. A more specific indication of the allocation was made by the tribunal in Spence v. Costa Rica in the context of Article 10.18.1 of the CAFTA:

If the Claimants cannot establish, to an objective standard, that they first acquired knowledge of the breaches and losses that they allege in the period after 10 June 2010, they fall at the first hurdle. To surmount this obstacle, each claimant must show, in respect of each property claim, that they have a cause of action, a distinct and legally significant event that is capable of founding a claim in its own right, of which they first became aware in the period after 10 June $2010 .{ }^{182}$

57. A distinction should thus be drawn between actual and constructive knowledge. The burden of proving the former falls with the claimant, whereas the latter may be allocated to the respondent, together with a requirement of diligence from the claimant ${ }^{183}$ and a presumption that information in the public domain ${ }^{184}$ or in the hands of a company belonging to the same economic group as the investor is constructively expected to be known by the claimant. ${ }^{185}$

\section{ABUSE OF RIGHT}

58. In international law, the doctrine of abuse of right (or abus de droit) is an expression of the well-established principle of good faith. ${ }^{186}$ In Orascom v. Algeria, which is reported in this volume, the tribunal made a concise but illuminating application of this doctrine in a context (a multiplicity of legal suits brought against the same State by several vertically connected companies under the same overall control) different from those in which the doctrine has most frequently featured in commercial arbitration, e.g. the allegedly abusive exercise of a contractual right, ${ }^{187}$ and investment arbitration, i.e. a corporate restructuring effected for the sole purpose of benefiting from the protection of a treaty at a time when the dispute is already foreseeable.

59. In the investment context, the objection has been sometimes formulated as an abuse of process in two different ways. The first is to consider that the investment itself is - through the restructuring - made abusively and, due to the absence of good faith, there is no investment. Such is the approach followed in Phoenix v. Czech Republic, where the tribunal concluded that there was no investment to be protected. ${ }^{188}$ Another approach is to consider that, even if there is technically a qualifying investment, it does not "deserve" the protection of the treaty and an action seeking such protection is an inadmissible abuse of the right to bring an

\footnotetext{
181 Philip Morris v. Uruguay, para. 503. 182 Spence v. Costa Rica, para. 163.

183 Grand River v. United States, paras. 66-7; Mercer v. Canada, para. 6.24.

184 Grand River v. United States, para. 68. ${ }^{185}$ Mercer v. Canada, para. 6.9.

186 Churchill v. Indonesia, para. 492; Himpurna case, para. 318.

187 General Dynamics United Kingdom Ltd v. The State of Libya, ICC Arbitration Case No. 19222/

EMT, Final Award (5 January 2016) [General Dynamics v. Libya], paras. 324-33.

188 Phoenix v. Czech Republic, paras. 100-13.
} 
action. Such is the approach followed in Philip Morris v. Australia, where the claimant made a restructuring of its corporate structure after the dispute (relating to the adoption of a plain packaging measure by Australia affecting the claimant's cigarette business) had become foreseeable. ${ }^{189}$ The tribunal set the following test:

it is clear, and recognised by all earlier decisions that the threshold for finding an abusive initiation of an investment claim is high. It is equally accepted that the notion of abuse does not imply a showing of bad faith. Under the case law, the abuse is subject to an objective test and is seen in the fact that an investor who is not protected by an investment treaty restructures its investment in such a fashion as to fall within the scope of protection of a treaty in view of a specific foreseeable dispute. ${ }^{190}$

In this context, (i) it is an objective test in that intent to "abuse" is established by the behaviour and not by a subjective search of bad faith in the relevant corporate officers, and the behaviour that must be established by the respondent includes three elements: (ii) an investor that is not protected by an investment treaty, (iii) restructures its investment in order to fall within the scope of protection of another treaty, and (iv) a time when a specific dispute is foreseeable. The tribunal adds that (v) the standard of proof is "high", an addition that can be understood in similar terms to my earlier discussion of the standard of proof in case of alleged violations of international public policy. ${ }^{191}$

60. The reasoning of the tribunal requires four additional clarifications. First, the tribunal noted that the dispute must be "foreseeable" for the objection to be one of admissibility because if the restructuring takes place after the dispute has effectively arisen, the tribunal would "normally" lack jurisdiction ratione temporis. ${ }^{192}$ Secondly, before the dispute is "foreseeable" there is no abuse of right which may be derived from the mere restructuring of the transaction to benefit from the treaty. ${ }^{193}$ It is legitimate for an investor to structure its transaction in such a way as to benefit from such protection. However, the lack of foreseeability does not mean that the right to bring an action may not be abused in some other way, as it will be discussed by reference to Orascom. Thirdly, "foreseeability" is not a "subjective" element to be established by reference to whether the relevant corporate officers actually foresaw the dispute. It is an objective standard of "reasonableness" in the light of the relevant circumstances. ${ }^{194}$ Fourthly, the main purpose of the restructuring must be to benefit from the protection of the treaty and, significantly, the respondent only needs to show that the restructuring took place at a time when the dispute was already foreseeable for the burden of proof to shift to the claimant to establish a different driving purpose. In Philip Morris, the

\footnotetext{
189 Philip Morris v. Australia, paras. 585-8. See also Mobil Corporation, Venezuela Holdings, B.V., Mobil Cerro negro Holding, Ltd., Mobil Venezolana de Petróleos Holdings, Inc., Mobil Cerro Negro, Ltd., and Mobil Venezolana de Petróleos, Inc. v. Bolivarian Republic of Venezuela, ICSID Case No. ARB/07/27, Decision on Jurisdiction (10 June 2010), paras. 169ff; Gremcitel v. Peru, paras. 180ff (with further reference to cases).

190 Philip Morris v. Australia, para. 539.

191 See further Chevron Corporation (USA) and Texaco Petroleum Company (USA) v. The Republic of Ecuador, UNCITRAL, PCA Case No. 34877, Interim Award (1 December 2008), para. 143.

192 Philip Morris v. Australia, para. 539. ${ }^{193}$ Philip Morris v. Australia, paras. 540-4.

194 Philip Morris v. Australia, para. 566.
} 
tribunal concluded that "the Claimant ha[d] not been able to prove that tax or other business reasons were determinative for the restructuring. From all the evidence on file, the Tribunal can only conclude that the main and determinative, if not sole, reason for the restructuring was the intention to bring a claim under the Treaty". ${ }^{195}$ This is consistent with its earlier statement that the respondent has to "allege and prove the facts on which its objections are based; and, to the extent that the Respondent has established a prima facie case, [it is] for the Claimant to rebut this evidence". 196

61. Although the difference between the Phoenix approach, which excludes jurisdiction (due to a lack of an investment), and the Philip Morris approach, which makes the claim inadmissible (as a result of the abuse of right), has been downplayed by some tribunals, ${ }^{197}$ it is not without consequence. Aside from the basic differences relating to the moment in the arbitration proceeding when the argument can be made, ${ }^{198}$ the burden of proof, ${ }^{199}$ and the scope for review of the decision, ${ }^{200}$ the lack of jurisdiction presupposes the inexistence of the investment due to bad faith. In other words, if bad faith is a definitional component, it no longer matters "when" the circumvention took place, as it does for admissibility. As soon as it is confirmed, there is no longer an "investment" for purposes of the treaty, and thus the well-established difference between "initial" and "subsequent" illegality is erased. ${ }^{201}$

62. As noted earlier, the tribunal in Orascom v. Algeria addressed the operation of abuse of right in a different context, namely multiple claims deliberately brought against a State under different treaties by different but vertically connected companies under the same overall control and based on the same facts. The reasoning blazed a trail through three different considerations. The first was a basic statement of Hersch Lauterpacht recalling that "there is no legal right, however well established, which could not, in some circumstances, be refused recognition on the ground that it has been abused". ${ }^{202}$ This statement provided support for the test succinctly formulated by the tribunal in the following terms: " $[t]$ he doctrine of abuse of rights prohibits the exercise of a right for purposes other than those for which the right was established". ${ }^{203}$ The second consideration was a rather unexpected admission, during the hearing, by the ultimate controlling shareholder of all the claimant companies:

\footnotetext{
195 Philip Morris v. Australia, para. 584. 196 Philip Morris v. Australia, para. 495.

197 Gremcitel v. Peru, para. 181; Pac Rim Cayman LLC v. Republic of El Salvador, ICSID Case No. ARB/09/12, Decision on the Respondent's Jurisdictional Objections (1 June 2012) [Pac Rim v. El Salvador - Jurisdiction], para. 2.10 (recognising the distinction in theory but dismissing it as "a distinction without a difference").

198 HOCHTIEF Aktiengesellschaft v. Argentine Republic, ICSID Case No. ARB/07/31, Decision on Liability (29 December 2014), para. 149.

199 Awdi v. Romania, para. 212.

200 See Z. Douglas, The International Law of Investment Claims (Cambridge University Press, 2009), para. 307.

201 See Viñuales 2018, on which this discussion relies.

202 Orascom v. Algeria, para. 541 quoting Hersch Lauterpacht, The Development of International Law by the International Court (London: Stevens \& Sons, 1958), p. 164.

203 Orascom v. Algeria, para. 540.
} 
when I was defending the interests of Orascom Telecom [Holding] [OTH] only, we would use the Egyptian treaty, because that's the instance now that is corresponding, and it's the direct. ... Then when things start to go worse, you say, "Listen, guys, it's not going to end up there. There is an Italian treaty, so the mother company can go." Then when I sell under the gun - and again I come to the different nature of my claim ... I used the Luxembourg treaty. ${ }^{204}$

The third consideration was the broader context of investment arbitration, in which claims are routinely brought by companies within the same group against the very same measures under different treaties, and they sometimes lead to contradictory results that highlight flaws in the system. ${ }^{205}$ In this context, the reasoning of the tribunal can be understood as an attempt to tread carefully between the Scylla of excluding any indirect shareholder claim and the Charybdis of allowing a blatant misuse of the right to bring a claim under several applicable treaties. The tribunal concluded that such resort to multiple suits had to be seen "as an abuse of the system of investment protection", which was a "ground for the inadmissibility of the Claimant's claims and preclude[d] the Tribunal from exercising its jurisdiction over this dispute". ${ }^{206}$ It stressed that such ground defeated the admissibility of the claims and, careful to circumscribe the scope of its ruling, it also stated that it reflected the:

peculiar facts of the case, in which (i) the group of companies of which the Claimant was part was organized as a vertical chain; (ii) the entities in the chain were under the control of the same shareholder; (iii) the measures complained of by the various entities in the chain were the same and thus the dispute notified to Algeria by those entities was in essence identical; and (iv) the damage claimed by the various entities was, in its economic essence, the same. ${ }^{207}$

It subsequently contrasted its conclusion with the widely criticised contradictory awards in CME v. Czech Republic and Lauder v. Czech Republic, and observed that "in the fifteen years that have followed those cases, the investment treaty jurisprudence has evolved, including on the application of the principle of abuse of rights (or abuse of process)". ${ }^{208}$

63. The Orascom award is not the only case where the doctrine of abuse of right has been applied in an unintuitive but important context. In Himpurna, a majority of the tribunal relied on this doctrine to drastically reduce the damages awarded to the claimant to take into account the extremely difficult position of the respondent arising from the 1997 financial crisis in Indonesia. Significantly, the doctrine was applied pre-emptively, that is on the understanding that no abuse of right had taken place and none should be allowed to occur. According to the tribunal:

\footnotetext{
204 Orascom v. Algeria, para. 544.

205 CME Czech Republic B.V. v. The Czech Republic, UNCITRAL Rules, Partial Award (13 September 2001) [CME v. Czech Republic] (finding a breach of all the provisions invoked by the claimant and ordering compensation, which was set later); Ronald S. Lauder v. The Czech Republic, UNCITRAL Rules, Final Award (3 September 2001) [Lauder v. Czech Republic] (finding one breach, rejecting claims for other breaches and awarding no damages).

206 Orascom v. Algeria, para. 545. 207 Orascom v. Algeria, para. 546.

208 Orascom v. Algeria, para. 547.
} 
the doctrine of abuse of right must be applied in favour of [the respondent] to prevent the claimant's undoubtedly legitimate rights from being extended beyond tolerable norms, on the grounds that it would be intolerable in the present case to uphold claims for lost profits from investment not yet incurred. ${ }^{209}$

This is yet another illustration of the plasticity of the doctrine of abuse of right, which can operate in very different contexts, for different purposes, in a retrospective or pre-emptive manner.

\section{CORRUPTION}

64. Allegations of corruption have been in the past the main example of inconsistency with both legality requirements and international public policy. In this context, the main question is often not one of definition - as corruption is universally banned, in both domestic and international $\operatorname{law}^{210}$ - but one of proof and, specifically, one relating to the standard, not the burden of proof. The burden is clearly on the party making this allegation of improper conduct, normally the respondent. $^{211}$ The standard of proof raises the questions discussed earlier in connection with international public policy, namely the determination of the appropriate standard ("clear and convincing evidence" or the mere "balance of probability") and, in actual practice, the assessment of the persuasiveness of the evidence, irrespective of the formal standard. In this section, I discuss three possible outcomes of such allegations. On one side of the spectrum, an allegation of corruption may be established at the required standard of proof, as was the case in both World Duty Free v. Kenya and Metal-Tech v. Uzbekistan. On the other side of the spectrum, the allegations may remain insufficiently proven, despite attempts to raise suspicion with respect to the investor's behaviour, as in Karkey v. Pakistan, reported in this volume. But the possible outcomes do not end there. There are cases, such as Lao Holdings v. Laos or Churchill v. Indonesia, where an allegation of corruption cannot be established and, yet, the evidence is sufficient to conclude that there has been improper behaviour from the investor which makes its claims inadmissible. The focus of the following paragraphs is on the legal reasoning underpinning these outcomes.

65. Metal-Tech v. Uzbekistan concerned a joint venture for the extraction and commercialisation of molybdenum, a mineral. The claimant committed acts of corruption in violation of domestic law and hence of Article 1(1) of the applicable BIT (a legality clause), and the tribunal concluded, as a result, that it did not have jurisdiction to hear any of the claims. In its reasoning, the tribunal made a number of useful observations. First, it noted that the legality requirement could not be bypassed through the operation of an MFN clause. Echoing an earlier award from the same president, "one must be under the treaty to claim through

209 Himpurna case, para. 330. 210 See e.g. Metal-Tech v. Uzbekistan, paras. 282-6, 289-93.

211 Karkey v. Pakistan, para. 497; Lao Holdings N.V. v. Lao People's Democratic Republic, ICSID Case No. ARB(AF)/12/6, Award (6 August 2019) [Lao Holdings v. Laos], para. 96. In the set-aside proceedings brought by India before the District Court of The Hague against the award in Devas v. India, the District Court considered the mere allegation of corruption in domestic criminal proceedings to be insufficient to set aside the award. See De Republiek India v. CC/Devas Mauritius Ltd, ECLI: NL:RBDHA:2018:15532, para. 4.66. 
the treaty". ${ }^{212}$ Secondly, although it decided the case by reference to the applicable Uzbek law on corruption, it also emphasised the relevance of several international instruments on corruption ${ }^{213}$ as well as best practices, including the so-called "red flags" raising suspicion regarding the activities of "consultants" or "advisers". 214 Thirdly, the tribunal avoided taking a position on the burden and standard of proof because the evidence of suspicious payments came from the claimant itself, although the tribunal did refer to "whether corruption has been established with reasonable certainty". ${ }^{215}$ It further noted that "corruption is by essence difficult to establish and that it is thus generally admitted that it can be shown through circumstantial evidence". ${ }^{216}$ Finally, following the decision in World Duty Free, the Metal-Tech tribunal acknowledged the unbalanced effects of a finding of corruption but it added that "the idea ... is not to punish one party at the cost of the other, but rather to ensure the promotion of the rule of law, which entails that a court or tribunal cannot grant assistance to a party that has engaged in a corrupt act". ${ }^{217}$

66. At the opposite side of the spectrum, in Karkey v. Pakistan, an investment in the provision of electricity from "powerships" came to a dead end when the government issued a notice of termination of the underlying contract. The allegation of corruption arose, in essence, from a violation of Pakistan's public procurement rules, although the government referred to several specific instances of alleged corruption, including a covert "scheme" which was raised very late in the proceedings. The tribunal dismissed the allegations. The decision is noteworthy for its discussion of the burden and standard of proof. Regarding the first, the tribunal noted that the respondent:

bears the burden of proof with respect to its allegations of corruption pursuant to the well-established principle onus probandi incumbit actori (the party that asserts must prove). However, the Tribunal finds that it can shift the burden of proof with respect to corruption and fraud to Karkey should the Tribunal be satisfied that there is unequivocal (or unambiguous) prima facie evidence in this regard. ${ }^{218}$

On the second, it noted that "there is a large consensus among international tribunals regarding the need for a high standard of proof of corruption", which it identified as "clear and convincing evidence". ${ }^{219}$ The tribunal considered, in this light, several allegations of corruption through a local consultant were made, but the respondent admitted that the connections that the relevant person had with the government were distant and not comparable to those in Metal-Tech. Significantly,

\footnotetext{
212 Metal-Tech v. Uzbekistan, para. 145. See also Mesa v. Canada, para. 401.

213 Metal-Tech v. Uzbekistan, paras. 290-1. ${ }^{214}$ Metal-Tech v. Uzbekistan, para. 293.

215 Metal-Tech v. Uzbekistan, para. 239-43.

216 Metal-Tech v. Uzbekistan, para. 243. See further Oostergetel v. The Slovak Republic, UNCITRAL Final Award (3 April 2012), para. 303.

217 Metal-Tech v. Uzbekistan, para. 389.

218 Karkey v. Pakistan, para. 497. Allegations of corruption must not be made lightly. In Karkey, the tribunal placed on the record that Pakistan had "made the Tribunal spend a large part of the Hearing on unfounded and suspicions arguments of corruption" (para. 1069). In Cortec v. Kenya, paras. 400-1, the tribunal went further and reduced by 50 per cent the costs awarded to the respondent on that basis.

219 Karkey v. Pakistan, para. 492.
} 
the award discussed the operation of the so-called "red flags", which Pakistan had invoked. It noted the following in this regard:

The Tribunal is not satisfied that these so-called "red flags", consisting solely of questions, are of sufficient weight and credibility to shift Pakistan's burden of proving its allegations of corruption to Karkey, so as to require Karkey to exonerate itself. Several questions raised by Pakistan are based on alleged acts or omissions by Pakistani government officials which are not proven and if such acts and omissions are established, they may have many other explanations than corruption by Karkey. ${ }^{220}$

This paragraph suggests that the "red flags" cannot be treated as presumptions because they require proof, rather than mere plausibility, to shift the burden of proof. Yet, this paragraph also suggests that when the content of such "red flags" is established (which is less demanding than actual proof of corruption), the burden of proof shifts to the claimant to "exonerate itself". Another noteworthy element of this decision concerns the handling of a serious allegation of corruption at a late stage in the proceedings. Between the filing of its rejoinder and the holding of the hearing, the respondent attempted to introduce a new allegation, with new evidence, that a vast corruption scheme orchestrated by Karkey had been brought to its attention by a third party, which demanded a very substantial payment to disclose the relevant documents. ${ }^{221}$ The tribunal rejected a request for additional document production and it refused to hear a witness, although it admitted some new evidence during the hearing. The respondent made, in this regard, what the tribunal characterised as a "thinly veiled accusation of lack of impartiality" and of failure of the tribunal's duties. The tribunal recalled the lack of evidence in the record supporting the claim of corruption, including the inability of domestic authorities to ascertain such claims at the domestic level. It concluded that the allegations could not "lead to a finding of corruption or even a shifting of the burden of proof" and that its conclusion would not change if the "balance of probabilities" standard was applied. ${ }^{222}$

67. Between these two extremes, the decisions in Lao Holdings v. Laos and Churchill v. Indonesia are instructive in two main ways. In both cases the respondent alleged corruption, which could not be established as such. Yet, in both cases the tribunals concluded that there had been improper behaviour which rendered the claims inadmissible. Of note, whereas the Churchill tribunal specifically addressed this issue at the level of admissibility, ${ }^{223}$ the Lao Holdings tribunal framed them as a matter to be decided on the merits. ${ }^{224}$ The latter approach is odd, and it may have been dictated by the peculiar circumstances of the case. After reviewing and dismissing all the claims on the merits, noting at times that the bad faith of the investor had to be taken into account in the assessment, the tribunal concluded as follows:

While the Tribunal has already rejected the Claimants' allegations for the reasons detailed above, the Claimants' bad faith initiation of some investments and bad faith

220 Karkey v. Pakistan, para. 521 (emphasis added).

221 Karkey v. Pakistan, paras. 525-43.

222 Karkey v. Pakistan, para. 543. ${ }^{223}$ Churchill v. Indonesia, para. 528.

224 Lao Holdings v. Laos, para. 89. 
performance of other investment agreements (as detailed above) and the attempt of [the controlling shareholder] to compromise the integrity of this arbitration through an inducement to [a local contact] not to testify provide added reasons to deny the Claimant $\ldots$ the benefit of Treaty protection. ${ }^{225}$

Lao Holdings is also of interest for the reliance on two international instruments as a reflection of a "principle of customary international law applicable ... to root out corruption" used "to obtain or retain business or other undue advantage in relation to the conduct of international business" 226 and the clear assertion that "proof of corruption at any stage of the investment may be relevant depending on the circumstances". ${ }^{227}$ Regarding the burden and the standard of proof, it was not disputed that the former was borne by the respondent ${ }^{228}$ and the tribunal decided the dispute on the latter concluding that an allegation of corruption required "clear and convincing evidence" rather than a balance of probabilities. ${ }^{229}$ This difference was decisive in the tribunal's assessment of the corruption allegation, which it rejected in its entirety at the level of the higher standard but accepted in some instances at the level of the lower standard. ${ }^{230}$ The relevance of the latter finding was explained as concerning the merits of the fair and equitable treatment claim. ${ }^{231}$ In fact, the defence argument did not operate technically but practically in that, although the tribunal assessed the claims on the merits, it did so after having formed the opinion that the claims did not deserve protection. ${ }^{232}$

\section{WILFUL BLINDNESS}

68. The outcome of Churchill v. Indonesia can also be situated between the two extremes of the spectrum defined in the previous discussion. Despite an allegation of corruption by the respondent, the tribunal considered the claims inadmissible on a different ground which is - like corruption - at the heart of international public policy, namely fraud in the form of wilful blindness. This refers to lack of due diligence when making the investment through a third party which had clearly engaged in fraudulent behaviour. The broader context of this decision is therefore provided by allegations of inconsistency with international public policy, which, as the tribunal noted, have been dealt with at the levels of jurisdiction, ${ }^{233}$ admissibility $^{234}$ or merits. ${ }^{235}$ The tribunal framed the issue as one of admissibility ${ }^{236}$ but relied on an adapted form of a test developed - by another tribunal ${ }^{237}$ - to assess

\footnotetext{
225 Lao Holdings v. Laos, para. 280.

226 Lao Holdings v. Laos, para. 105 (referring to the UN Convention against Corruption, Article 16(1), and the OECD Convention on Combating Bribery of Foreign Public Officials in International Business Transactions, Article 1(1)).

227 Lao Holdings v. Laos, para. 105. ${ }^{228}$ Lao Holdings v. Laos, para. 96.

229 Lao Holdings v. Laos, paras. 109-10. According to the tribunal, this was a result of "the general proposition that the graver the charge, the more confidence there must be in the evidence relied on" (para. 110 and authorities cited therein).

230 Lao Holdings v. Laos, paras. 133, 148 and 154-7. $\quad 231$ Lao Holdings v. Laos, para. 162.

232 See e.g. Lao Holdings v. Laos, para. 239.

233 Inceysa v. El Salvador, para. 339(2); Europe Cement v. Turkey, para. 180; Anderson v. Costa Rica, paras. 26, 55, and 59 .

234 Plama v. Bulgaria, para. 146. $\quad 235$ Malicorp v. Egypt, para. 116.

236 Churchill v. Indonesia, para. 507. $\quad{ }^{237}$ Minnotte v. Poland, para. 163.
} 
fraud at the merits stage. Given that the fraud had been committed by a third party through which the claimant had made its investment, the focus of the test was not on whether the claimant itself had committed acts of corruption or fraud, but on whether it should have known that its business partner had done so. As noted by the tribunal:

Considering the specific circumstances of the present case, the Tribunal will assess the standard of willful blindness - also referred to as "conscious disregard" or "deliberate ignorance" - by focusing on the level of institutional control and oversight deployed by the Claimants in relation to the licensing process, whether the Claimants were put on notice by evidence of fraud that a reasonable investor in the Indonesian mining sector should have investigated, and whether or not they took appropriate corrective steps. ${ }^{238}$

This amounts to a duty of due diligence imposed on the investor, which the tribunal usefully characterised, by reference to some other decisions, as follows:

Investment tribunals also held that investors must exercise a reasonable level of due diligence, especially when investing in risky business environments ... The scope of the due diligence depends on the particular circumstances of each case, such as the general business environment, and includes ensuring that a proposed investment complies with local laws, as well as investigating the reliability of a business partner and that partner's representations before deciding to invest. ${ }^{239}$

Failure to display due diligence in such a context amounts to a breach of international public policy and makes the claims inadmissible.

69. The respondent bore the burden of establishing fraud ${ }^{240}$ at a standard characterised by the "balance of probabilities", ${ }^{241}$ which was clearly met, among others, by the filing of the forged documents by the claimant in the arbitration. Thereafter the burden of showing actual diligence shifted to the claimant. The tribunal found, without hesitation, that the scheme relying on forged documents had been put in place intentionally ${ }^{242}$ and, although the authors of the forgery remained unidentified, the claimant had failed to exercise due diligence in the circumstances. $^{243}$ The claims were therefore declared inadmissible. Of note, the tribunal did not establish corruption or fraud "by" the claimant but only "wilful blindness", namely lack of due diligence when making the investment through a third party which had clearly engaged in fraudulent behaviour. This mirrors Lao Holdings v. Laos, where corruption could not be established by clear and convincing evidence but only on the balance of probabilities, or with Philip Morris v. Australia, where the abuse of right was established without the need to prove actual bad faith. Different tribunals have used the plasticity of the relevant tests, the broad rules on the burden and the standard of proof, and different possible framings of the defence argument as affecting jurisdiction, admissibility or the merits to give expression to essentially factual conclusions. This is not to say that the law relating to these defence arguments is unsettled. As it has been shown, as a

\footnotetext{
238 Churchill v. Indonesia, para. 504. $\quad 239$ Churchill v. Indonesia, para. 506.

240 Churchill v. Indonesia, paras. 238 and 551. 241 Churchill v. Indonesia, para. 244.

242 Churchill v. Indonesia, para. 511. $\quad{ }^{243}$ Churchill v. Indonesia, paras. 516-27.
} 
matter of principle, these and other defence arguments all address the possibility of relying on a treaty and, seen from this angle, they share certain common features relating to the burden and standard of proof and their ordinary stage of operation (as a rule at the jurisdictional and admissibility stages; only exceptionally at the merits stage).

\subsection{Specific Scope of the Primary Norm}

70. The difference between defence arguments concerning the scope of the primary norm and those circumscribing the perimeter of the treaty is a matter of degree. Terms such as "carve-outs", "derogations", "reservations", "exemptions", "safeguards" or "exclusions" may be used to express the same idea, namely that certain measures do not fall under the scope of a primary norm. The assumption is that the measure falls under the general perimeter of the applicable treaty but is excluded from the scope of a specific clause of the treaty. If the claimant brings only a claim for breach of that specific clause, then the effect will be similar to that of general exclusions, namely lack of jurisdiction over the claim. By contrast, the tribunal's jurisdiction over other claims is unaffected. The effects can also be framed at the level of liability, whether to exclude responsibility arising from the covered measures (Continental Casualty v. Argentina) or to create a strong presumption of conformity with a treaty clause (as suggested by a non-disputing party in Spence v. Costa Rica ${ }^{244}$ ). In addition, differences in terminology depend not only on the treaty in question but also on the context in which it is applied. For example, the term "derogation" as it is used in the trade and investment case law can be assimilated to that of "carve out", ${ }^{245}$ whereas in the context of human rights law, it conveys a different idea, namely that of an exceptional excuse based on the specificity of the situation (public emergency). ${ }^{246}$

71. Two decisions reported in this volume, Mobil v. Canada ${ }^{247}$ and Mercer v. Canada, ${ }^{248}$ discuss the operation of NAFTA Article 1106(5) (exclusion of measures not expressly brought under the prohibition of local content requirements), Article 1108(1) (exclusion of individually designated measures from the

\footnotetext{
244 Spence v. Costa Rica, para. 157.

245 See e.g. Canada-Certain Measures Affecting the Renewable Energy Generation Sector; CanadaMeasures Relating to the Feed-In Tariff Program, WT/DS412/AB/R, WT/DS426/AB/R (6 May 2013), para. 5.56 (characterising Article III:8(a) of the GATT as a "derogation" relating to public procurement, which excludes the application of Article III in its entirety); Mesa v. Canada, para. 427 (discussing also the public procurement carve-out).

246 See International Covenant on Civil and Political Rights, 16 December 1966, 999 UNTS 171, Article 4; Human Rights Committee, General Comment 29, States of Emergency (Article 4), UN Doc. CCPR/C/21/Rev.1/Add.11 (2001); Convention for the Protection of Human Rights and Fundamental Freedoms, 4 November 1950, 213 UNTS 221, Article 15; Case of Brannigan and McBride v. The United Kingdom, ECtHR Application 14553/89, 14554/89, Judgment (25 May 1993), paras. 40-74 (assessing a derogation from Article 5); American Convention on Human Rights, 22 November 1969, 1144 UNTS 123, Article 27.

247 Mobil Investments Canada Inc. and Murphy Oil Corporation v. Government of Canada, ICSID Case No. ARB(AF)/07/4, Decision on Liability and on Principles of Quantum (22 May 2012) [Mobil v. Canada], paras. 172-3, 210-65, 284-357, 367-413. See also the dissent, paras. 1-41.

248 Mercer v. Canada, paras. 6.27-6.67.
} 
application of certain primary norms in Chapter 11), and Article 1108(7)(a) (exclusion of public procurement from the application of certain primary norms in Chapter 11). Mercer also refers, without providing a detailed discussion, to Article 1503(2) of NAFTA (application of NAFTA Chapter 11 to State enterprises only to the extent they exercise "governmental authority"). Another type of clausespecific carve-out is found in the annexes to certain treaties, and they concern measures adopted for certain purposes. Although arbitral practice is scarce, at least two such clauses have been addressed - in one case to a very limited extent - in the case law, namely Annex 10-B(4)(b) of the Oman-US FTA (concerning Article 10.6.1 on expropriation) ${ }^{249}$ and Annex 10-C of the CAFTA (concerning Article 10.7 on expropriation). ${ }^{250}$ For present purposes, these specific carve-outs are sufficiently representative of four main aspects relating to the operation of such clauses: their definition by reference to specific measures, including those identified by their purpose, or to the nature of an entity; their operation at the level of either jurisdiction or merits; the different approaches to their formulation (as paragraphs within a clause, reservations to be notified under a "reservation" clause, or annexes to certain clauses); and the implications of the framing of these clauses for matters such as the burden of proof or the interpretative approach.

\section{SCOPE OF THE PROHIBITION OF PERFORMANCE REQUIREMENTS (ARTICLE I IO6(5) OF THE NAFTA)}

72. Mobil v. Canada concerned the adoption of a set of guidelines concerning research and development expenditures which the claimant saw as more onerous for its two affected petroleum development projects than the previously applicable framework. The tribunal was asked to decide inter alia whether the guidelines constituted prohibited performance requirements under Article 1106(1) of the NAFTA and whether they had been "reserved" (i.e. excluded from the application of Article 1106) through the operation of Article 1108(1). The relation between these two allegations is also of interest because it illustrates the operation of a complex system of rules, carve-outs and reservations arising from the NAFTA. Article 1106(1) contains a closed list of prohibited performance requirements. Article 1106(5) states that the prohibition in paragraph (1) does not apply to "any requirement other than the requirements set out in those paragraphs". On this basis, the respondent argued that the scope of the measures identified in Article 1106(1) had to be interpreted restrictively. The tribunal rejected the argument on the implicit - grounds that the restrictive nature of the prohibition is fleshed out by means of a closed list, but it does not require a restrictive interpretation of the terms within that list. ${ }^{251}$ One significant consideration, which the tribunal carefully framed as relevant but not decisive, was that Canada had notified the relevant measures as a "non-conforming measure" (with Article 1106) under the reservation system set out in Article 1108(1). ${ }^{252}$

249 Al-Tamimi v. Oman, para. 368.

251 Mobil v. Canada, paras. 214-16.
250 Spence v. Costa Rica, paras. 157 and 161.

252 Mobil v. Canada, para. 245. 
RESERVATION OF SPECIFICALLY IDENTIFIED MEASURES (ARTICLE I IO8(I) OF THE NAFTA)

73. The main contribution of Mobil v. Canada for present purposes is the detailed analysis of the operation of the reservations system. Article 1108(1) provides that certain primary norms (Articles 1102, 1103, 1106 and 1107) do not apply to "any existing non-conforming measure" which is specifically identified by a NAFTA Party in a schedule to Annex I to the NAFTA, or to the "continuation or prompt renewal" of such measures, or to an amendment of said measures "to the extent that the amendment does not decrease the conformity of the measure, as it existed immediately before the amendment, with Articles 1102, 1103, 1106 and 1107'. Annex I further specifies the elements that the description of a reserved measure must have. Importantly, it notes in paragraph 2(f)(ii) that the reserved measure "includes any subordinate measure adopted or maintained under the authority of and consistent with the measure". The main issue at stake was how to interpret this provision and, specifically, whether the guidelines on research and development expenditure were subordinate measures adopted or maintained under the reserved measure, with the result that Article 1106 was not applicable. ${ }^{253}$

74. There was no dispute that the reserved non-conforming measure was a statute identified in the schedule. But beyond that agreement, most issues were contentious. The majority of the tribunal made a number of observations of general interest, although it presented its reasoning as applying to the specific circumstances of the case. First, it noted that it was sufficient for a reservation to identify the statute, even if no mention was made of the specific sections of this instrument on which further regulations and administrative acts were adopted. ${ }^{254}$ Secondly, it observed that the terms "adopted or maintained" did not exclude subordinate measures adopted after the entry into force of the NAFTA. ${ }^{255}$ Thirdly, according to the majority, the terms "under the authority" required consideration of the relations of "the subordinate measure with the reserved measure" and possibly also, depending on the circumstances of the case, with "other subordinate measures". ${ }^{256}$ Fourthly, and perhaps most importantly, the terms "consistent with" were characterised in two main respects. On the one hand, the assessment of consistency had to be made not only with the overarching "measure" (in casu, the statute) but also "depending on the facts of the case ... in reference to the reserved measure along with other subordinate measures that are themselves under the authority of, and consistent with the reserved measure". ${ }^{257}$ This was key on the facts of the case. On the other hand, the majority drew an analogy with Article 1108(1)(c) (subsequent amendment of reserved measures) and noted:

If a NAFTA Party were to amend a measure subject to a reservation, such amendment cannot decrease the conformity of the reserved measure. The Majority sees nothing in the structure of the NAFTA to suggest that a NAFTA Party can potentially circumvent the constraint imposed by the amendment provision through the issuance of a

\footnotetext{
253 Mobil v. Canada, paras. 256, 264-5. 254 Mobil v. Canada, paras. 278-9.

255 Mobil v. Canada, paras. 294-5. ${ }^{256}$ Mobil v. Canada, para. 331.

257 Mobil v. Canada, para. 339.
} 
disguised amendment, executed via a subordinate measure that was to unduly expand the non-conforming features of a reservation. While the amendment standard in Article 1108 and the consistency standard in paragraph 2(f) are not identical provisions, they are substantively reinforcing and tug in the same direction, namely, to ensure that the reservations are not expanded or altered to such a degree so as to enlarge the non-conformity of the reservation vis-à-vis the obligation against which the measure is reserved. ${ }^{258}$

Applying this test, the majority concluded that the guidelines were inconsistent with the overarching statute and related subordinate measures and, as the challenged measures were not reserved, they were in breach of Article 1106 of the NAFTA. One arbitrator dissented on this specific point observing, among other things, that the majority had conflated the requirements for a subordinate measure to be covered by the reservation (namely "authority" and "consistency") with those applicable to an amendment of the overarching measure (degree of non-conformity with certain NAFTA disciplines). ${ }^{259}$

75. The effect of a reservation is not spelt out in the decision of the majority precisely because the challenged measure is said not to be covered by the reservation. The partially dissenting opinion appended to the award is useful here because it reached the opposite conclusion "on the merits" and, on this basis, stated that "the question of damages does not arise". Yet, the considerations made in connection with Continental Casualty v. Argentina remain relevant. If a provision states explicitly that one or more other provisions of the treaty (primary norms) do not apply to certain measures identified in a schedule or an annex, the ordinary conclusion would be that the measures are excluded from the perimeter of those primary norms and, hence, that the tribunal has no jurisdiction to hear a claim alleging that the excluded measures are in violation of the inapplicable primary norms. Even if, in both cases, extensive briefing of factual issues may be required to establish "inconsistency", the distinction is not without consequence. For example, the burden of proof may be allocated differently. As stated by the tribunal in Mesa v. Canada, "[i]t is for the Claimant to establish the factual elements necessary to sustain the Tribunal's jurisdiction over the challenged measures". ${ }^{260}$ Conversely, when the issue is framed as part of the merits, the allocation changes:

On the merits, the Claimant must establish the facts showing that the challenged measures are contrary to the substantive protections of the NAFTA [and] where the Respondent raises a defense - for instance, that the FIT Program involves procurement under Article 1108(7)(a) and 1108(8)(b) - it must establish the facts necessary to sustain the defense. ${ }^{261}$

Because the defence arguments under Articles 1108(7)(a) and 1108(8)(b) are framed as part of the inquiry on the merits, the burden is placed on the respondent. This is correct if the public procurement derogation or exemption, which the Mesa

\footnotetext{
258 Mobil v. Canada, para. 341. 259 Mobil v. Canada, Dissent, paras. 20-4.

260 Mesa v. Canada, para. 236. See further Philip Morris v. Australia, para. 495; Apotex v. United States, para. 150

261 Mesa v. Canada, para. 237.
} 
tribunal called a "carve-out", operates at the merits stage. ${ }^{262}$ But the very principle of allocating the burden of proving the facts underlying jurisdiction to the claimant would apply if the defence argument were framed, for example, as the carve-out in Article 21 ECT discussed earlier. In fact, in Mercer v. Canada, the same defence argument relating to public procurement (Article 1108(7)(a) of the NAFTA) was framed as a jurisdictional matter. The tribunal concluded, by a majority, that the challenged measure "[fell] within the procurement exception in NAFTA Article 1108(7)(a)" and, as a result, that it had no jurisdiction over the relevant claimant's claims for breach of the inapplicable primary norms (Articles 1102 and 1103 of the NAFTA). Practical considerations may explain why tribunals have framed the same argument in different terms, including the way the defence arguments are argued by the parties. But such framing has legal consequences.

\section{PUBLIC PROCUREMENT CARVE-OUTS (ARTICLE I IO8(7)(A) OF THE NAFTA)}

76. Article 1108(7)(a) succinctly provides that: "Articles 1102, 1103 and 1107 do not apply to: (a) procurement by a Party or a state enterprise." The reported decision in Mercer v. Canada, as well as some other prior decisions, have shed light on the operation of this clause. In Mercer, the question was whether the specificities of the contractual relationship (a 2009 Electricity Purchase Agreement) between a State agency and a pulp mill from which it purchased electricity changed the transaction to an extent that the public procurement clause was not applicable. The tribunal, which used the term "exception" to characterise this clause, stated that the ordinary meaning of the term "procurement" was broad and not restrictive. ${ }^{263}$ It also emphasised a point that subsequently had important practical effects, namely that in assessing whether the transaction constituted "procurement", it had to focus "on substance, not on mere form". ${ }^{264}$ Given the brevity of the clause and the fact that the parties were in agreement that the State agency was a State entity for the purpose of Article 1108(7)(a), the only remaining issue was whether the specificities of the contractual relationship excluded a characterisation as "procurement". One specificity was a term (the so-called "generator baseline" or GBL) used for a dual purpose, namely, on the one hand, to define the obligation of the State agency to sell electricity to the pulp mill and, on the other hand, to define the level beyond which the State agency would buy or procure electricity from the mill. The tribunal found (by a majority) that this dual purpose was immaterial because, as a matter of substance, not form, the GBL was part of the definition of the procurement transaction. ${ }^{265}$ The same logic was applied to another contractual specificity, i.e. an exclusivity clause, which the tribunal (by a majority) also found to be part of the procurement transaction. ${ }^{266}$ Of note, the effect of the application of the procurement clause was that the tribunal

\footnotetext{
262 The tribunal concluded that the challenged measure fell under the public procurement carve-out, which excludes public procurement from the application of certain primary norms, and on this basis stated that "The claims in respect of these provisions are, therefore, dismissed", Mesa v. Canada, para. 466.

263 Mercer v. Canada, para. 6.34. $\quad{ }^{264}$ Mercer v. Canada, para. 6.42.

265 Mercer v. Canada, paras. 6.45 and 6.47. ${ }^{266}$ Mercer v. Canada, para. 6.49.
} 
lacked jurisdiction over the claims for violation of Articles 1102 and 1103 (1107 was not relevant in the case) arising from the procurement measures. However, the effect is partial in nature, as the tribunal asserted jurisdiction over the claim for breach of Article 1105 arising from the same measures. ${ }^{267}$ More generally, this decision is significant because it provides guidance on how to address attempts at what could be called a "dépècement" or the "break-up" of the transaction into different pieces to escape the operation of the procurement clause.

77. As noted earlier, this clause has been discussed in some previous cases. For the definition of "procurement", tribunals - including the Mercer tribunal ${ }^{268}$ often refer to the characterisation provided in $A D F$ v. United States:

In its ordinary or dictionary connotation, "procurement" refers to the act of obtaining, "as by effort, labor or purchase". To procure means "to get; to gain; to come into possession of". In the world of commerce and industry, "procurement" may be seen to refer ordinarily to the activity of obtaining by purchase goods, supplies, services and so forth. Thus, governmental procurement refers to the obtaining by purchase by a governmental agency or entity of title to or possession of, for instance, goods, supplies, materials and machinery. ${ }^{269}$

Several other questions arising from Article 1108(7)(a) of the NAFTA have been addressed in the case law.

78. A notable decision, which has already been mentioned, is that in Mesa v. Canada. The dispute concerned the allegedly arbitrary and unfair design and implementation of a feed-in-tariff (FIT) scheme which had resulted in the claimant not being awarded any contract to sell electricity to Ontario. It is a useful complement to the earlier case law on Article 1108(7)(a) because it dispels a number of possible confusions arising from the wider NAFTA framework on public procurement as well as from international trade law. At the outset, the tribunal dismissed the proposition that "the mere characterization of a treaty term as an 'exception' requires an interpretation different from other treaty terms. Indeed, whatever their characterization, all terms of a treaty are subject to the ordinary rules of treaty interpretation." 270 Subsequently, the tribunal (acting by a majority) relied on the earlier case law, including $A D F$ v. United States, to characterise the broad and unqualified meaning of "procurement" in Article 1108(7)(a), which is not subject to the same limitations as in other chapters of the NAFTA (an argument which the claimant made by reference to Article 1001(5)) or elsewhere (an argument made by reference, in particular, to Article III:8(a) of the GATT). Specifically, reliance on Article 1108(7)(a) is not subject to the limitation that "procurement" must not be for commercial resale or that procurement by lower levels of government (e.g. provincial or municipal) is not covered. The rationale given by the majority was twofold. A first consideration was that:

267 Mercer v. Canada, paras. 6.50-6.51. $\quad{ }^{268}$ See Mercer v. Canada, para. 6.40.

269 ADF Group Inc. v. United States of America, ICSID Case No. ARB(AF)/00/1, Award (9 January 2003) [ADF v. United States], para. 161.

270 Mesa v. Canada, para. 405. 
It appears reasonable that a State be free to procure goods or services in a manner that yields maximum benefits for the local economy. Government purchasing of goods and services is an extremely important function, and procurement by way of formal purchasing procedures is frequently utilised as an instrument of policy. To this end, Article 1108(7)(a) allows for preferential treatment of local suppliers, when a Party is engaged in formal purchasing of goods and services. ${ }^{271}$

A second consideration was that, as "the obligations in Chapter 11 apply to both federal and provincial governments, it is coherent that exceptions to these obligations also apply to federal and provincial governments". ${ }^{272}$ Overall, the majority concluded that the FIT programme constituted "procurement" under Article 1108(7)(1) of the NAFTA and, therefore, the claims for violation of Articles 1102 and 1103 had to be dismissed. As noted earlier in this study, the dismissal intervened at the merits stage.

79. One additional element of the Mesa decision concerns the interplay or sequence between the "carve-out" in Article 1108(7)(1) and the MFN clause in the NAFTA (Article 1103). The claimant sought to circumvent the public procurement clause by relying on the MFN clause to import more favourable standards (in fact, other MFN clauses without a public procurement carve-out) from two other treaties. The tribunal firmly rejected this construction stating that:

For an MFN clause in a base treaty to allow the importation of a more favorable standard of protection from a third party treaty, the applicability of the MFN clause in the base treaty must first be established. Put differently, one must first be under the treaty to claim through the treaty. Thus, the Claimant must first establish that the MFN provision of the base treaty applies. Then, relying on that provision, it may be able to import a more favorable standard of protection from a third party treaty. ${ }^{273}$

As noted earlier in this study, a similar argument has been attempted and rejected in the same terms in connection with a requirement that the investment is made in accordance with domestic law. ${ }^{274}$ This suggests that understanding the operation of a clause as one which defines the perimeter of an instrument (a treaty, a chapter or certain primary norms within the treaty or chapter) entails a sequence of application, i.e. both the public procurement clause and the legality clause apply at a conceptually earlier stage than the MFN clause. The same would not be true if the operation of a defence argument were framed differently, e.g. as a presumption of conformity with a primary norm or as a mere interpretation guide. The decisions in Al-Tamimi v. Oman and Spence v. Costa Rica illustrate this point.

\section{ANNEXES CARVING OUT MEASURES FOR CERTAIN PURPOSES}

80. Some treaties, particularly FTAs, contain annexes to the sections devoted to certain investment protection disciplines, usually expropriation. By way of illustration, Annex 10-B(4)(b) of the Oman-US Free Trade Agreement states, in relation to the expropriation clause (Article 10.6.1), that "[e]xcept in rare circumstances, non-discriminatory regulatory actions by a Party that are designed and

271 Mesa v. Canada, para. 420.

273 Mesa v. Canada, para. 401.

272 Mesa v. Canada, para. 463.

274 Metal-Tech v. Uzbekistan, para. 145. 
applied to protect legitimate public welfare objectives, such as public health, safety, and the environment, do not constitute indirect expropriations". The formulation makes it clear that this is a matter to be reviewed at the merits stage. It can be understood as a rebuttable presumption that the measures covered do not constitute a breach of the expropriation clause. As such, the respondent only has to establish prima facie that the measures are covered by the carve-out and then the burden of proof shifts to the claimant, which in all events has the overall burden of proving the facts underlying its expropriation claim. Although there is limited practice in this area, the decision of the tribunal in Al Tamimi v. Oman sheds some light on the effect of such clauses. The dispute concerned the continued operation of a limestone quarry in violation of domestic environmental law. The tribunal addressed the effect of Annex 10-B(4)(b) only in passing. After rejecting the claim for expropriation on the merits, it simply added that:

Any claim for indirect expropriation based on the Respondent's actions after 17 February 2009 would also have to confront the express stipulation in Annex 10-B.4(b) of the US-Oman FTA that non-discriminatory regulatory actions by a State designed and applied to protect legitimate public welfare objectives, including protection of the environment - and, the Tribunal infers, the enforcement of Omani private property laws - do not constitute indirect expropriations. ${ }^{275}$

This addition, and its context, suggest that an Annex drafted in such terms operates as a presumption of lawful conduct or, in other words, of lack of breach. The consequence is similar to the dismissal of the claims in Mesa v. Canada with one caveat. Whereas the Annex introduces only a rebuttable presumption, in the case of public procurement clauses, once the measure falls under the terms of the clause, certain primary norms become inapplicable.

81. The understanding of such clauses as rebuttable presumptions also finds indirect support in the decision in Spence v. Costa Rica. The case concerned the expropriation of certain parcels partly falling within the limits of a natural reserve. The tribunal declined jurisdiction to hear most claims, including those for which the Annex (10-C(4)(b) of the CAFTA) carving out certain measures from the expropriation clause (Article 10.7) would have been relevant. But two nondisputing parties, El Salvador and the United States, made submissions on the effect of such Annex. For El Salvador:

in the case of claims of indirect expropriation, a claimant would have the burden of rebutting the strong presumption created by CAFTA Annex 10-C that a State's nondiscriminatory regulatory measures designed to protect the environment do not constitute an indirect expropriation. ${ }^{276}$

The United States made a more nuanced argument disentangling the presumption, which would arise from international law even in the absence of an Annex, and the Annex itself which merely provides guidance to tribunals:

Under international law, where an act is a bona fide, non-discriminatory regulation, it will not ordinarily be deemed expropriatory. The burden is on a claimant to show that

275 Al Tamimi v. Oman, para. 368. $\quad 276$ Spence v. Costa Rica, para. 157. 
the government measure in issue destroyed all, or virtually all, of the economic value of its investment or interfered with it to such a similar extent and so restrictively so as to support a conclusion that it had been taken. It also requires an assessment of the extent to which the conduct interferes with reasonable expectations, as well as the character of the governmental action. Annex 10-C, paragraph 4(b) is not an exception but is rather intended to provide tribunals with additional guidance in determining whether an indirect expropriation has occurred. ${ }^{277}$

The operation of such clauses as presumptions brings the discussion closer to the level of the assessment of whether there has been a breach of a primary norm.

\subsection{Assessment of Breach of the Primary Norm}

82. Defence arguments that concern the assessment of a breach presuppose that the treaty - and the relevant investment disciplines - are applicable and that there are no reasons preventing reliance on such legal bases. The natural element of these defence arguments is therefore the assessment of the merits of the claims. As for the arguments discussed earlier, the framing of the argument matters greatly. In Part I, I noted that much is conceded if, for example, the police powers doctrine is invoked as an exceptional excuse for State action/inaction which would otherwise constitute a breach of an investment discipline. The scope of operation of this doctrine (whether it operates in the context of investment disciplines other than expropriation), the understanding of its elements (whether they are cumulative requirements or indicia of reasonableness or due diligence), the approach to interpretation and the degree of deference (more or less restrictive, although this may be mostly a practical rather than technical matter), and even the grounds for application (whether it needs to be "incorporated" by a treaty clause or simply applies as a relevant and applicable customary norm) may all be affected by how the argument is framed. The alternative is, of course, that the exercise of police powers cannot be exceptional, because it is what States are meant to do; it is an expression - and a particularly important and wide-ranging one - of what defines them as States, i.e. their sovereignty. Given the practical importance of the police powers doctrine, it is a useful entry point to start the discussion of defence arguments under the present heading.

\section{EXERCISE OF POLICE POWERS ${ }^{278}$}

83. The police powers doctrine, as this defence argument is generally known in investment law, following the domestic law of the United States, is extremely important in practice. ${ }^{279}$ The term was coined by US Chief Justice John Marshall

277 Spence v. Costa Rica, para. 161. $\quad 278$ This section relies on Viñuales 2013, 2014 and 2018.

279 Cases where this defence argument has been applied, sometimes to dispose of a claim, include: CME v. Czech Republic, para. 603; Marvin Roy Feldman Karpa v. United Mexican States, ICSID Case No. ARB(AF)/99/1, Award (16 December 2002), paras. 103, 112; Saluka v. Czech Republic, paras. 253-65; BG Group Plc. v. Republic of Argentina, UNCITRAL, Award (24 December 2007), para. 268; AWG Group Ltd v. Argentine Republic, UNCITRAL, Decision on Liability (30 July 2010), paras. 149-50; Total S.A. v. Argentine Republic, ICSID Case No. ARB/04/01, Decision on Liability (27 December 2010), para. 197; Tza Yap Shum v. Peru, para. 145; El Paso v. Argentina, paras. 236-41, 243; Les Laboratoires Servier, S.A.S., Biofarma, S.A.S., Arts et Techniques du Progres S.A.S. v. Republic of Poland, UNCITRAL, Award (Redacted) (14 February 2012) [Servier v. Poland], paras. 
in the early nineteenth century, ${ }^{280}$ but it has a longer history in international and domestic law. Such history must be briefly recalled in order to dispel a deep and important misunderstanding. The term "police" power in its original English meaning came from the Greek politeia, through the intermediary of the old French term police. ${ }^{281}$ It means "policy" or "government" or, in other words, the exercise of governmental functions. In the specific context of international law, the term was already used in Vattel's Le Droit des gens (1758), who observed, for example, that "individuals are not so perfectly free in the economy or government of their affairs, as not to be subject to the laws and regulations of police made by the sovereign". ${ }^{282}$ Vattel appears to be the source of the use of this term in United States public law. ${ }^{283}$ This simple genealogy recalls three main points, which are uncontroversial, although not always given full effect. First, the exercise of police or governmental powers is a corollary of State sovereignty, and it is the rule, not an exception that must be derived from or incorporated into a treaty. Secondly, the natural context where this power is exercised is to govern economic activity. Thirdly, the foundation is older and broader than any specific statement that may be found in US law. It is, indeed, grounded in general international law and it must not be reduced to any specific domestic order or to a specific clause such as eminent domain.

84. The latter point has been recalled on several occasions by the ICJ or its predecessor, the PCIJ. In Certain German Interests in Polish Upper Silesia, the PCIJ noted indeed that:

the only measures prohibited are those which generally accepted international law does not sanction [the French text says "ne permet pas"] in respect of foreigners; expropriation for reasons of public utility, judicial liquidation and similar measures are not affected by the Convention. ${ }^{284}$

This wording describes the legal situation of measures not explicitly regulated by a Convention granting certain prerogatives to Poland over German assets. The Court had noted earlier that, in respect of those cases not explicitly regulated by the

569-70, 584; SAUR International S.A. v. Argentine Republic, ICSID Case No. ARB/04/4, Decision on Jurisdiction and Liability (6 June 2012), paras. 396-401; TECO Guatemala Holdings, LLC v. Republic of Guatemala, ICSID Case No. ARB/10/23, Award (19 December 2013), paras. 490-3.

280 Brown v. Maryland, 25 U.S. (12 Wheat) 419, 442-3 (1827). See S. Legarre, "The Historical Background of the Police Power" (2007) 9 University of Pennsylvania Journal of Constitutional Law 745.

281 A. Smith, Lectures on Jurisprudence (Oxford: Clarendon Press, 1978), at 5, quoted in Legarre, at 752 .

282 E. de Vattel, Le Droit des gens, ou principes de la loi naturelle appliqués à la conduite et aux affaires des Nations et des Souverains [1758]. See The Law of Nations, Or, Principles of the Law of Nature, Applied to the Conduct and Affairs of Nations and Sovereigns, with Three Early Essays on the Origin and Nature of Natural Law and on Luxury, B. Kapossy, R. Whatmore, (eds.) (Indianapolis: Liberty Fund, 2008) Book I, chapter XX, para. 255.

283 See Ch. Fenwick, "The Authority of Vattel" (1913) 7 The American Political Science Review 395; Ch. Fenwick, "The Authority of Vattel II" (1914) 8 The American Political Science Review 375; W. W. Crosskey, Politics and the Constitution in the History of the United States (Chicago: The University of Chicago Press, 1953), at 147; Legarre, at 753-5 (discussing these and other sources).

284 Certain German Interests in Polish Upper Silesia (Merits), Judgment (25 May 1926), P.C.I.J. Series A No. 7 [Certain German Interests], at 22. 
treaty, the rules of general international law remained applicable. ${ }^{285}$ Measures not prohibited by general international law include, according to the Court, "expropriation for reasons of public utility, judicial liquidation and similar measures". Similarly, in the Oscar Chinn case, the PCIJ stated this point in more general terms:

The Court, though not failing to recognize the change that had come over Mr Chinn's financial position, a change which is said to have led him to wind up his transport and shipbuilding businesses, is unable to see in his original position - which was characterized by the possession of customers and the possibility of making a profit anything in the nature of a genuine vested right. Favourable business conditions and good-will are transient circumstances, subject to inevitable changes; the interests of transport undertakings may well have suffered as a result of the general trade depression and the measures taken to combat it. No enterprise - least of all a commercial or transport enterprise, the success of which is dependent on the fluctuating level of prices and rates - can escape from the chances and hazards resulting from general economic conditions. Some industries may be able to make large profits during a period of general prosperity, or else by taking advantage of a treaty of commerce or of an alteration in customs duties; but they are also exposed to the danger of ruin or extinction if circumstances change. Where this is the case, no vested rights are violated by the State. ${ }^{286}$

More recently, the ICJ has enumerated the type of measures that a State may refer to in order to establish that it has acted à titre de souverain over a given territory. These include, without limitation:

legislative acts or acts of administrative control, acts relating to the application and enforcement of criminal or civil law, acts regulating immigration, acts regulating fishing and other economic activities, naval patrols as well as search and rescue operations. $^{287}$

This paragraph leaves no doubt as to the legal connection between sovereignty and the regulation of economic activities. The exercise of police powers is the very expression of governmental activity. It does not require any special basis other than sovereignty and, importantly, the absence of such exercise may be retained, in a territorial dispute, as an indication that the relevant State does not exercise sovereignty over a territory.

85. The formal source underlying the exercise of police powers is general international law. It is widely accepted, including in the practice of investment tribunals, that such exercise results from customary international law. By way of illustration, the tribunal in $C M E$ v. Czech Republic noted that:

deprivation of property and/or rights must be distinguished from ordinary measures of the State and its agencies in proper execution of the law. Regulatory measures are

\footnotetext{
285 Certain German Interests, at 21.

286 Oscar Chinn Case, Judgment (12 December 1934) P.C.I.J. Series A/B No. 63 [Oscar Chinn], at 88 (emphasis added).

287 Territorial and maritime dispute (Nicaragua v. Colombia), Judgment, I.C.J. Reports 2012, p. 624, para. 80 (emphasis added).
} 
common in all types of legal and economic systems in order to avoid use of private property contrary to the general welfare of the (host) State. ${ }^{288}$

Tecmed $\mathrm{v}$. Mexico endorsed the actionable character of the police powers doctrine in a foreign investment dispute in the following terms:

The principle that the State's exercise of its sovereign powers within the framework of its police power may cause economic damage to those subject to its powers as administrator without entitling them to any compensation whatsoever is undisputable. $^{289}$

In Methanex v. United States, the tribunal applied the police powers doctrine characterising it as follows:

as a matter of general international law, a non-discriminatory regulation for a public purpose, which is enacted in accordance with due process and, which affects, inter alios, a foreign investor or investment is not deemed expropriatory and compensable unless specific commitments had been given by the regulating government to the then putative foreign investor contemplating investment that the government would refrain from such regulation. ${ }^{290}$

Similarly, in Saluka v. Czech Republic, the tribunal stated, referring to the Methanex case, that:

the principle that a State does not commit an expropriation and is thus not liable to pay compensation to a dispossessed alien investor when it adopts general regulations that are "commonly accepted as within the police powers of States" forms part of customary law today. ${ }^{291}$

86. For the operation of this defence argument, the wide recognition since the late eighteenth century of the exercise of police powers as a corollary of sovereignty, with customary grounding, has a number of implications. First, it does not need any legal basis other than customary international law to operate in a foreign investment dispute. Secondly, it is inaccurate to characterise it as a sort of exception or even carve-out confined to a specific investment discipline (expropriation) and not applicable to others (FET, FPS, MFN, national treatment, etc.). As noted earlier, it is the very essence of a State to govern economic activity. The exercise of police powers may be subject to limitations (e.g. investment protection standards, human rights, trade disciplines, etc.) by either customary or treaty norms. But such limitations are different from a State's power to regulate. Confining police powers to expropriation, as suggested by the reasoning of some tribunals, ${ }^{292}$ is a conceptual mistake with significant practical implications. It understands the rule

288 CME v. Czech Republic, para. 603.

289 Técnicas Medioambientales Tecmed S.A. v. United Mexican States, ICSID Case No. ARB(AF)/00/ 2, Award (29 May 2003) [Tecmed v. Mexico], para. 119.

290 Methanex Corporation v. United States of America, NAFTA (UNCITRAL), Award (3 August 2005) [Methanex v. United States], part IV, ch. D, para. 7 (emphasis added).

291 See Saluka v. Czech Republic, para. 262 (emphasis added).

292 Suez, Sociedad General de Aguas de Barcelona S.A. and InterAgua Servicios Integrales del Agua S.A. v. Argentine Republic, ICSID Case No. ARB/03/17, Decision on Liability (30 July 2010) [Suez v. Argentina - 03/17], para. 148. 
(the power to regulate) as the exception (its limitations) and, even more concerning, it looks at the rule from the perspective of a single limitation (expropriation). Thirdly, as a basic manifestation of sovereignty, the exercise of police powers is not subject to any specific test or set of requirements akin to those of other defence arguments. Investors should have the burden of proving that such exercise is abusive, although tribunals are often ambiguous on this issue. They can do so in many ways, such as showing the absence of a public purpose or of due process or of appropriate compensation or the presence of discrimination or of a vested interest or prior specific assurance, but also the lack of a specific basis authorising a State to take certain action (e.g. absence of grounds for the revocation of a licence) or an arbitrary application of such basis. In what follows, I discuss these three implications by reference to the investment case law, including the decisions of the tribunals in Philip Morris v. Uruguay ${ }^{293}$ and Quiborax v. Bolivia, which are reported in this volume. ${ }^{294}$

87. Regarding, first, the legal basis for the operation of the police powers doctrine in a foreign investment dispute, Saluka v. Czech Republic offers a useful starting point to understand the implications of the discussion. Despite the wide recognition of police powers as an expression of sovereignty grounded in customary international law, the tribunal's reasoning implies that the customary norm could only be applied if it has been incorporated into the applicable treaty:

The Tribunal acknowledges that Article 5 of the Treaty [an expropriation clause] in the present case is drafted very broadly and does not contain any exception for the exercise of regulatory power. However, in using the concept of deprivation, Article 5 imports into the Treaty the customary international law notion that a deprivation can be justified if it results from the exercise of regulatory actions aimed at the maintenance of public order. ${ }^{295}$

This statement is debatable. The application of the police powers doctrine, as a customary norm, does not depend upon a clause incorporating it into the treaty, ${ }^{296}$ unless the treaty otherwise excludes the application of relevant customary law. This ambiguity is somewhat dissipated when the tribunal adds, in the same paragraph, a reference to Article 31(3)(c) of the Vienna Convention on the Law of Treaties:

In interpreting a treaty, account has to be taken of "any relevant rules of international law applicable in the relations between the parties" - a requirement which the International Court of Justice ("ICJ") has held includes relevant rules of general customary international law.

293 Philip Morris v. Uruguay, paras. 287-307.

294 Quiborax S.A. and Non Metallic Minerals S.A. v. Plurinational State of Bolivia, ICSID Case No. ARB/06/2, Award (16 September 2015), and Partially Dissenting Opinion (7 September 2015) [Quiborax v. Bolivia], paras. 196-227.

295 Saluka v. Czech Republic, para. 254 (emphasis added).

296 The ICJ made this point in the Nicaragua case in a more extreme context where the customary and treaty norms had the same content: "customary international law continues to exist and to apply, separately from international treaty law, even where the two categories of law have an identical content", Nicaragua-Merits, para. 179. 
This statement is certainly correct and it has been reiterated in Philip Morris v. Uruguay, in the context of measures adopted to fight the consumption of tobacco. ${ }^{297}$ Yet, in order to avoid further ambiguity, this statement requires four additional clarifications, namely that (i) customary law does not require "incorporation" to be taken into account, (ii) it may be taken into account not only for "interpretation" purposes but also (iii) to govern a situation which is not specifically addressed in the treaty and, above all, (iv) that there are no legal grounds to assume, without further and specific reasoning to this effect, that a treaty not addressing a given question nevertheless acts as lex specialis (and in the very specific form of exclusionary lex specialis) with respect to a customary norm that specifically addresses such a question.

88. It is worth recalling, in this context, the decision in AAPL v. Sri Lanka, where the tribunal noted that:

the Bilateral Investment Treaty is not a self-contained closed legal system limited to provide for substantive material rules of direct applicability, but it has to be envisaged within a wider juridical context in which rules from other sources are integrated through implied incorporation methods, or by direct reference to certain supplementary rules, whether of international law character or of domestic law nature. ${ }^{298}$

It is of course possible that the wording of an investment treaty may exclude certain customary norms (which are not of peremptory nature), but only when the parties have specifically intended to do so. Investment tribunals need to analyse that point explicitly. Frequent examples of such supplementary norms include the customary rules on treaty interpretation and application codified in the VCLT or the customary law of State responsibility for internationally wrongful acts, although the supplementing role has a wider scope. The tribunal in Accession Mezzanine v. Hungary recalled this point when stating that:

the interpretation and application of the BIT is governed by international law, as is any treaty, and the expropriation clause is, obviously, a key part of the BIT. Second, it may not be possible to consider the scope and content of the term "expropriation" in the BIT without considering customary and general principles of international law, as well as any other sources of international law in this area ... It is true that BITs have become the most reliable source of law in this area, as have the awards of ICSID, other investor-state tribunals acting under the UNCITRAL Arbitration Rules, and other modern-day tribunals, such as the Iran-U.S. Claims Tribunal, state practice, and writings of scholars. But that is not inconsistent with the continuing relevance of customary and general principles of international law, at least as to BIT obligations that are silent as to scope and content, as well as any other sources of international law with respect to expropriation. ${ }^{299}$

297 Philip Morris v. Uruguay, paras. 290-1.

298 Asian Agricultural Products Ltd (AAPL) v. Republic of Sri Lanka, ICSID Case No. ARB/87/3, Final Award (27 June 1990) [AAPL v. Sri Lanka], para. 21 (emphasis added).

299 See Accession Mezzanine Capital L.P. and Danubius Kereskedohaz Vagyonkezelo v. Hungary, ICSID Case No. ARB/12/3, Decision on Respondent's Objection under Arbitration Rule 41(5) (16 January 2013) [Accession Mezzanine v. Hungary], paras. 67-8 (emphasis added). 
This quotation reflects the tendency of tribunals to look at investment treaties as "the most reliable source of law in this area" but, at the same time, it highlights that even for questions that are addressed in investment treaties, such as expropriation, reference to customary law may still be necessary for interpretative purposes. The customary norm may apply together with the treaty provision in order to clarify the contents of this provision. ${ }^{300}$ A fortiori, when the applicable treaty does not govern the question expressly, the supplementary role of custom should be expected to be much greater. The overall import of the treaty (a treaty provision or a set of them) may still be understood as excluding custom, but this reasoning must be sufficiently spelt out in the tribunal's decision, rather than simply assumed. Understanding the supplementary role of custom, and its operation in the investment context, is important because investment treaties rarely address the extent of a State's regulatory powers explicitly and, even when they do so (e.g. carve-outs), this is not to be considered as replacing (and excluding) the customary norms expressing State sovereignty unless this is made clear by the text of the treaty.

89. Secondly, with respect to the characterisation and scope of operation of the police powers doctrine, the decision in Suez v. Argentina offers a useful starting point. In this case, an Argentine territorial subdivision (the province of Santa $\mathrm{Fe}$ ) had privatised its water and sewer services through a concession granted to foreign investors. In 2002-3, when a severe economic and social crisis hit Argentina, the government devalued its currency and froze the tariffs charged by Aguas Provinciales de Santa Fe (APSF), the investment vehicle, to end consumers. Eventually, APSF filed for bankruptcy and the concession contract was terminated. The shareholders of APSF brought an investment claim inter alia for breach of the expropriation, fair and equitable treatment and full protection and security clauses in the applicable bilateral investment treaty. Argentina argued, among others, that the measures challenged constituted an exercise of its police powers. The tribunal rejected this argument stating that this concept only applied in connection with breaches of the expropriation clause (and not other investment disciplines):

the application of the police powers doctrine as an explicit, affirmative defense to treaty claims other than for expropriation is inappropriate, because in judging those claims and applying such principles as full protection and security and fair and equitable treatment ... a tribunal must take account of a State's reasonable right to regulate. ${ }^{301}$

This reasoning is debatable. The legal basis for the exercise of police powers is separate and indeed prior to the limitations that may arise from a subsequent treaty.

300 Legality of the Threat or Use of Nuclear Weapons, Advisory Opinion, I.C.J. Reports 1996, p. 226 [Legality of Nuclear Weapons], para. 25 ("The Court observes that the protection of the International Covenant of Civil and Political Rights does not cease in times of war, except by operation of Article 4 of the Covenant whereby certain provisions may be derogated from in a time of national emergency. Respect for the right to life is not, however, such a provision. In principle, the right not arbitrarily to be deprived of one's life applies also in hostilities. The test of what is an arbitrary deprivation of life, however, then falls to be determined by the applicable lex specialis, namely, the law applicable in armed conflict which is designed to regulate the conduct of hostilities. Thus whether a particular loss of life, through the use of a certain weapon in warfare, is to be considered an arbitrary deprivation of life contrary to Article 6 of the Covenant, can only be decided by reference to the law applicable in armed conflict and not deduced from the terms of the Covenant itself").

301 Suez. v. Argentina - 03/17, para. 148 (emphasis added). 
The tribunal may have meant that, from the specific perspective of the analysis of expropriation, such powers can be framed as the reservation of the exercise of police powers. Yet, it would still be inaccurate to characterise the rule, i.e. the entitlement, indeed the duty to regulate, as an exception to be made in the form of an "affirmative defence" against a specific investment discipline. In Quiborax v. Bolivia, the respondent argued that the revocation of a mining licence was a valid exercise of its regulatory powers prompted by the improper behaviour of the claimant. ${ }^{302}$ The tribunal rightly started its analysis by assessing whether the revocation was indeed a valid exercise of the police powers, which it rejected, and only then moved to assess whether the measure was expropriatory. ${ }^{303}$ This approach is correct and could be extended to the assessment of other claims. Conceptually, the assessment of impropriety in the exercise of regulatory powers may be, as such, sufficient to establish the breach of certain investment disciplines, such as fair and equitable treatment. But that is not always the case. Improper regulatory behaviour may not amount to an expropriation if it has not resulted in a "substantial deprivation" of the value of the investment. Similarly, if the deficiency concerns due process, there will be no discrimination involved in the impropriety and hence no breach as such of non-discrimination standards. States can and must regulate within the limits set to them by international law. Such limits arise from a wide range of treaties and norms, including investment treaties (in turn including expropriation clauses). Properly understood, the exercise of regulatory powers is permitted unless prohibited. It is the rule, not the exception. There are, however, many limits. Expropriation clauses are among them. Framing the question in these terms rather than as an "affirmative defence" has practical implications for the operation of other aspects of the police powers doctrine.

90. The third question is whether the police powers doctrine is subject to a "test" or, rather, it is a general inquiry regarding the reasonableness of State regulatory action. Commentators and investment tribunals often refer to criteria such as (i) the existence of a public purpose, (ii) non-discrimination, (iii) due process of law, (iv) just compensation, and/or (v) absence of inconsistent prior specific assurances. These criteria, and some others (such as the existence of a legal basis for State action and/or its application in a non-arbitrary manner and/or proportionality and/or good faith), do not settle the above question because they can be read either way. Useful and oft-quoted starting points for this discussion are the codification efforts conducted by private organisations such as the American Law Institute (ALI). Section 197(1)(a) of ALI's Restatement (Second) of the Law of Foreign Relations of the United States provides that "[c]onduct attributable to a state and causing damage to an alien does not depart from the international standard of justice indicated in $\S 165$ if it is reasonably necessary for ... the maintenance of public order, safety, or health" ${ }^{304}$ In the same vein, the commentary to section 712 of the third Restatement notes that:

A state is not responsible for loss of property or for other economic disadvantage resulting from bona fide general taxation, regulation, forfeiture for crime, or other action of the kind that is commonly accepted as within the police power of states, if it

302 Quiborax v. Bolivia, para. 201. $\quad{ }^{303}$ Quiborax v. Bolivia, paras. 201-27.

304 American Law Institute, Restatement (Second) of the Law of Foreign Relations of the United States, 1965, section 197(1)(a). 
is not discriminatory ... and is not designed to cause the alien to abandon the property to the state or sell it at a distress price. As under United States constitutional law, the line between "taking" and "regulation" is sometimes uncertain. ${ }^{305}$

Although the focus of the commentary is on expropriation, it also refers to "other economic disadvantage", and it highlights two criteria, namely (i) nondiscrimination, and (ii) public purpose (a contrario from the "design to cause the alien" a loss). The reporter's note 6 to section 712 adds, however, that the approach consists of a general assessment of all the circumstances:

It is often necessary to determine, in the light of all the circumstances, whether an action by a state constitutes a taking and requires compensation under international law, or is a police power regulation or tax that does not give rise to an obligation to compensate, even though a foreign national suffers loss as a consequence. (Emphasis added.)

Another oft-cited private codification effort is the so-called "Harvard Draft", Article 10(5) of which provides that:

An uncompensated taking of property of an alien or a deprivation of the use or enjoyment of property of an alien which results from the execution of the tax laws; from a general change in the value of currency; from the action of the competent authorities of the State in the maintenance of public order, health, or morality; or from the valid exercise of belligerent rights; or is otherwise incidental to the normal operation of the laws of the State shall not be considered wrongful, provided:

(a) it is not a clear and discriminatory violation of the law of the State concerned;

(b) it is not the result of a violation of any provision of Articles 6 to 8 of this Convention;

(c) it is not an unreasonable departure from the principles of justice recognized by the principal legal systems of the world; and

(d) it is not an abuse of the powers specified in this paragraph for the purpose of depriving an alien of his property. ${ }^{306}$

Again, this text refers not only to "takings" but also, more generally, to "a deprivation of the use or enjoyment of property of an alien". It then uses a wider set of criteria, some of which are entirely open (e.g. "an unreasonable departure from the principle of justice recognized by the principal legal systems of the world"). Letter (b) refers to three provisions relating to due process. Of note, these sources do not clearly refer to prior specific assurances as a criterion. However, some tribunals have done so, ${ }^{307}$ which may be explained as a matter of good faith ${ }^{308}$ or linked to the idea of vested rights mentioned in the Oscar Chinn case. ${ }^{309}$

\footnotetext{
305 American Law Institute, Restatement (Third) of the Law of Foreign Relations of the United States, 1986, section 712, commentary, letter (g).

306 L. B. Sohn, R. R. Baxter, "Draft Convention on the International Legal Responsibility of States for Injuries to Aliens" (1961) 55 American Journal of International Law 545 [Harvard Draft 1961], Article 10(5).

307 Methanex v. United States, part IV, ch. D, para. 7 (in the context of an expropriation claim), Waste Management, Inc. v. United Mexican States, NAFTA Arbitration, Case No. ARB(AF)/00/3, Award (30 April 2004) [Waste Management v. Mexico], para. 98 (in the context of a claim for breach of the international minimum standard of treatment).

308 Revere Copper and Brass, Inc. v. Overseas Private Investment Corporation, Arbitration Tribunal, 24 August 1978, 56 I.L.R. 258 [Revere Copper], para. 271.

309 Oscar Chinn, at 88
} 
91. From these authorities, it remains unclear whether the assessment must follow a cumulative list of requirements applicable in each case or, rather, a more general inquiry of reasonableness taking into account all circumstances. But the latter view matches the sources better, as the criteria mentioned are not the same, a specific reference to all the circumstances of the case is made, and some criteria are simply not mentioned and yet used in the case law. In this context, the decision in Quiborax v. Bolivia is of interest precisely because, in analysing whether the challenged measure - which the claimant saw as an expropriation and the respondent merely as revocation of a licence - was a valid exercise of Bolivia's police powers, it designed a "test" of regulatory propriety specifically tailored to the regulatory measure:

The Tribunal must thus consider whether, in light of all the circumstances, the Revocation Decree was a legitimate cancellation of the Claimants' concessions in the exercise of Bolivia's sovereign power to sanction violations of Bolivian law and is therefore not a compensable taking or whether it is a veritable taking disguised as the exercise of the State's police powers. This will depend on whether (i) the Revocation Decree is based on actual violations of Bolivian law by the Claimants; (ii) whether those violations of Bolivian law are sanctioned with the termination of the concessions (whether by revocation, cancellation, annulment or otherwise), and (iii) whether the revocation was carried out in accordance with due process. ${ }^{310}$

After reviewing the facts in this light, the tribunal concluded that the cancellation could not be seen as a proper exercise of Bolivia's regulatory powers. Notably, the tribunal premised its analysis on the need to take into account all the circumstances of the case (by reference to ALI's third Restatement), and the test it used is, in many ways, a selection of some relevant criteria to the assessment of regulatory propriety. Significantly, the tribunal distinguished in practice (although not in theory ${ }^{311}$ ) between the assessment of regulatory propriety and the assessment of the conditions for breach of the relevant clause (expropriation). ${ }^{312}$ Regulatory impropriety is a necessary but not a sufficient step for a finding of expropriation (although it may be sufficient in other contexts, such as a claim for fair and equitable treatment).

92. Understanding the inquiry in these terms also has implications for the allocation of the burden of proof. Seen from this perspective, the question is no longer which party has to prove the facts underlying the requirements of an "affirmative defence" or an "exception" but, instead, who has the burden of proving regulatory impropriety and, more specifically, that a measure has a public purpose and/or that it amounts to discrimination and/or that it was enacted without respect for due process and/or that it has had certain effects and/or that it was adopted despite prior specific assurances to the contrary and/or that there was wrongful conduct prompting State intervention and/or that domestic law allows for certain consequences, and so on. Establishing regulatory (im)propriety does not require establishing every single one of these criteria. These criteria are only indicative. This can explain why tribunals have not taken a clear stance on the

310 Quiborax v. Bolivia, para. 207 (emphasis added).

312 Quiborax v. Bolivia, paras. 201-27 and 228-34.

311 Quiborax v. Bolivia, para. 200. 
overall allocation of the burden of proof in this context and, instead, they have focused on allegations such as the lack of a public purpose (burden on the claimant) $^{313}$ or the existence of specific assurances (burden on the claimant) ${ }^{314}$ or the content of domestic law (on the respondent). ${ }^{315}$ However, the tribunal in Laboratoires Servier v. Poland offers a useful overall statement. It required the respondent to "come forward with prima facie justifications" and then noted:

In light of such explanations, it would be unreasonable to demand that Poland "prove the negative" in the sense of demonstrating an absence of bad faith and discrimination, or the lack of disproportionateness in the measures taken ... Thus, the burden then falls onto the Claimants to show that Poland's regulatory actions were inconsistent with a legitimate exercise of Poland's police powers. If the Claimants produce sufficient evidence for such a showing, the burden shifts to Poland to rebut it. ${ }^{316}$

In practice, both parties will address these issues in their submissions but the burden of proving regulatory impropriety ultimately rests with the claimant. Concluding otherwise would amount to presuming impropriety in State behaviour.

93. All in all, the exercise of police powers as a defence argument must operate as a presumption of regularity unless the claimant can show unreasonableness by pointing inter alia to the lack of public purpose, discrimination, arbitrariness, due process, effects and/or prior specific assurances, among other things (considerations of good faith). The importance of these inquiries may vary depending on the facts of the case and the investment disciplines invoked, but - in the abstract these are not to be considered as cumulative requirements to be demonstrated by the claimant or the respondent. They are indicia guiding a broader assessment of regulatory reasonableness.

\section{MARGIN OF APPRECIATION ${ }^{317}$}

94. Another defence argument which comes into play when assessing the merits of a claim for breach of a primary norm is the so-called "margin of appreciation doctrine" developed by the ECtHR ${ }^{318}$ on the basis of the practice of several European civil law jurisdictions, ${ }^{319}$ and subsequently adopted by other international bodies. ${ }^{320}$ This doctrine was initially formulated in the context of

\footnotetext{
313 Methanex v. United States, Part III, chapter B, pp. 2-28, and Part IV, chapter D, pp. 3-8; Chemtura Corporation (formerly Crompton Corporation) v. Government of Canada, UNCITRAL, Award (2 August 2010) [Chemtura v. Canada], paras. 137-43.

314 Methanex v. United States, part IV, ch. D, para. 6; Parkerings-Compagniet AS v. Republic of Lithuania, ICSID Case No. ARB/05/8, Award (11 September 2007) [Parkerings v. Lithuania], para. 338 .

315 Quiborax v. Bolivia, para. 214. $\quad 316$ Servier v. Poland, paras. 582-4.

317 This section relies on Viñuales 2012.

318 Y. Arai-Takahashi, The Margin of Appreciation Doctrine and the Principle of Proportionality in the Jurisprudence of the ECHR (Intersentia, 2002); A. Legg, The Margin of Appreciation in International Human Rights Law: Deference and Proportionality (Oxford University Press 2012); G. Letsas, "Two Concepts of the Margin of Appreciation" (2006) 26 Oxford Journal of Legal Studies 705; Y. Shany, "Toward a General Margin of Appreciation Doctrine in International Law?" (2005) 16 European Journal of International Law 907.

319 Arai-Takahashi, at 2-3.

320 In particular, the Inter-American Court of Human Rights and the United Nations Human Rights Committee, see Arai-Takahashi, at 4.
} 
derogations from human rights standards in accordance with Article 15 of the ECHR, ${ }^{321}$ and it was later used in the assessment of the scope of the individual rights granted under Articles 6 (due process) and 8 (right to private and family life, extended to cover environmental aspects) of the Convention, and Article 1 (right to private property) of the First Protocol. Its underlying rationale was formulated in the Handyside case as follows:

it is not possible to find in the domestic law of the various Contracting States a uniform European conception of morals. The view taken by their respective laws of the requirements of morals varies from time to time and from place to place, especially in our era which is characterised by a rapid and far-reaching evolution of opinions on the subject. By reason of their direct and continuous contact with the vital forces of their countries, State authorities are in principle in a better position than the international judge to give an opinion on the exact content of these requirements as well as on the "necessity" of a "restriction" or "penalty" intended to meet them ... This margin is given both to the domestic legislator ("prescribed by law") and to the bodies, judicial amongst others, that are called upon to interpret and apply the laws in force. ${ }^{322}$

Thus, the margin of appreciation is, in essence, a standard of deference given to the national authorities to assess a situation because of their better position to understand it.

95. This doctrine has been relied upon as a defence argument in investment arbitration both implicitly (without reference to the actual terms "margin of appreciation") and explicitly. A first strand of cases includes Methanex v. United States $^{323}$ and Glamis v. United States. ${ }^{324}$ In both cases, the tribunals considered that their role was not to judge the scientific conclusions on which the measures challenged by the investors were based, but only the acceptability of the process followed to reach such conclusions. Another strand of cases has explicitly referred to the margin of appreciation doctrine as derived from the practice of the ECtHR but reaching a different conclusion regarding its operation in the investment law context. In Chemtura v. Canada ${ }^{325}$ the tribunal took a nuanced position on whether its scope of review was limited by a margin of appreciation:

In assessing whether the treatment afforded to the Claimant's investment was in accordance with the international minimum standard, the Tribunal must take into account all the circumstances, including the fact that certain agencies manage highly specialized domains involving scientific and public policy determinations. This is not an abstract assessment circumscribed by a legal doctrine about the margin of appreciation of specialized regulatory agencies. It is an assessment that must be conducted in concreto. $^{326}$

321 Ireland v. United Kingdom, ECtHR Application No. 5310/71, Judgment (18 January 1978), A 25, para. 207, quoted in Arai-Takahashi, at 5.

322 Handyside v. United Kingdom, ECtHR Application No. 5493/72, Judgment (7 December 1976), A 24, para. 48, quoted in Arai-Takahashi, at 7-8.

${ }^{323}$ Methanex v. United States, part III, ch. A, para. 101.

324 See Glamis Gold Ltd v. The United States of America, NAFTA Arbitration (UNCITRAL), Award (16 May 2009) [Glamis v. United States], para. 779.

325 Chemtura v. Canada, paras. 133-4. ${ }^{326}$ Chemtura v. Canada, para. 123. 
In Von Pezold v. Zimbabwe, which is reported in this volume, the tribunal rejected the application of the margin of appreciation doctrine to the investment context because it was neither mentioned in the treaty nor a norm of customary law, and only precedents from the human rights context had been alleged by the respondent. ${ }^{327}$ In this context, the position taken by a majority of the tribunal in Philip Morris v. Uruguay with respect to the margin of appreciation doctrine is noteworthy. In its award, which is reported in this volume, the tribunal relied on Chemtura v. Canada and made a step further recognising that:

the "margin of appreciation" is not limited to the context of the ECHR but "applies equally to claims arising under BITs," at least in contexts such as public health. The responsibility for public health measures rests with the government and investment tribunals should pay great deference to governmental judgments of national needs in matters such as the protection of public health. ${ }^{328}$

96. Importantly, as in Chemtura, the tribunal observed that the challenged measures had been adopted in an effort to implement other international obligations of the respondent (in casu the Framework Convention on Tobacco Control or FCTC $^{329}$ whereas in Chemtura it was the Aarhus Protocol to the LRTAP Convention $^{330}$ and the Stockholm Convention on Persistent Organic Pollutants ${ }^{331}$ ). The tribunal deemed the FCTC (which was not binding on the home State of the investor) as a "point of reference" to determine the reasonableness of the challenged measures. ${ }^{332}$ The tribunal relied on the margin of appreciation doctrine to assess the reasonableness of two measures (a prohibition of misleading differentiation of products and the enlargement of warning images), which the claimants sought to challenge factually by noting that the measures were ineffective and punitive. By focusing on the "reasonableness" rather than on the actual effects of the measures, ${ }^{333}$ the tribunal showed deference to the choices of the host State and placed, in practice, the burden of proof on the claimant. The tribunal concluded the assessment stating that, in its view:

the present case concern[ed] a legislative policy decision taken against the background of a strong scientific consensus as to the lethal effects of tobacco. Substantial deference is due in that regard to national authorities' decisions as to the measures which should be taken to address an acknowledged and major public health problem. The fair and equitable treatment standard is not a justiciable standard of good government, and the tribunal is not a court of appeal. ${ }^{334}$

Like the police powers, the margin of appreciation doctrine operates for the assessment of whether a primary norm has been breached.

97. The application in Philip Morris v. Uruguay of both the police powers doctrine (in the context of the expropriation claim) and of the margin of

\footnotetext{
327 Von Pezold v. Zimbabwe, paras. 465-6. $\quad{ }^{328}$ Philip Morris v. Uruguay, para. 399.

329 Framework Convention on Tobacco Control, 27 February 2005, 2302 UNTS 166.

330 Protocol to the 1979 Convention on Long-Range Transboundary Air Pollution on Persistent Organic Pollutants (POPs), 24 June 1998, 2230 UNTS 79.

331 Stockholm Convention on Persistent Organic Pollutants, 22 May 2001, 2256 UNTS 119.

332 Philip Morris v. Uruguay, para. 401. 333 Philip Morris v. Uruguay, para. 409.

334 Philip Morris v. Uruguay, para. 418.
} 
appreciation doctrine (in the context of fair and equitable treatment) could give the impression that these doctrines operate in the context of different investment disciplines. Yet, as it was shown earlier in this chapter, this is a conceptual confusion. The proper - and simpler - articulation between the police powers doctrine and the margin of appreciation doctrine rests on three basic ideas. First, both are actionable expressions of the broader principle of respect for State sovereignty and, therefore, their operation is not confined to any single investment discipline but rather limited or circumscribed by all of them (as well as by the broader body of limitations on sovereignty arising from international law). Secondly, regulatory impropriety may arise from an abuse of the discretion afforded by the margin of appreciation doctrine, which is one criterion within the broader inquiry to determine whether a State has properly exercised its police powers. Thirdly, the margin of appreciation doctrine emphasises the need to respect the discretion of (or to defer to) State authorities for a specific reason, namely their better knowledge and assessment of what is needed for the public good. One may add, in the latter respect, the superior legitimacy of State authorities to do so.

98. There is a further complication which concerns a certain form of such deference, namely the tribunal's scope of review regarding the determinations of specialised domestic agencies. Here the rationale for deference stems from both the proximity to the local conditions and the scientific complexity of a matter. In such cases, tribunals must not focus on the science but on the process. However, questions of science and process are sometimes difficult to disentangle. ${ }^{335}$ Moreover, focusing only on process may sometimes lead to unsatisfactory solutions as, under some circumstances, it could be unreasonable to penalise a State that took a decision based on sound science but through a procedurally inefficient process. Assuming the result of the regulatory process to be the same, mere procedural breaches would be relevant only where and to the extent that they have imposed an unnecessarily heavy burden on the investor. In other terms, the articulation between science and process must leave some room to accommodate proportionality considerations. Such was the solution retained by the tribunal in Chemtura v. Canada, which considered that the delays in the registration process of a lindane-free replacement pesticide submitted by the claimant did not amount to a violation of Article 1105 of NAFTA. ${ }^{336}$

\section{PUBLIC INTEREST COUNTERCLAIMS}

99. The inclusion of public interest counterclaims in the discussion of defence arguments is based on the idea that the need to protect the public interest may not only be framed to "defend" the position of the respondent but also to challenge the position of the claimant. The counterclaim brought by Argentina in Urbaser v. Argentina for the alleged violation of the human right to water ${ }^{337}$ by the investor was unsuccessful on the merits. The reasoning of the tribunal is nevertheless noteworthy for its analysis of jurisdiction over counterclaims and the binding

\footnotetext{
335 In Methanex v. United States, the tribunal made explicit what it gathered from the discussion of scientific evidence. See Methanex v. United States, part III, ch. A, para. 102.

336 Chemtura v. Canada, paras. 217-20. 337 Urbaser v. Argentina, para. 1351.
} 
character of international obligations on investors. Moreover, it stands alongside two other examples of State counterclaims, in Perenco v. Ecuador ${ }^{338}$ and Burlington v. Ecuador ${ }^{339}$ - this time concerning environmental harm caused by the investor - which, although based on the applicable domestic law, further signal how the protection of the public interest may be framed as a claim rather than as a defence argument. Only this dimension is discussed in the following paragraphs.

100. Urbaser v. Argentina concerned a water concession granted by the province of Buenos Aires to a Spanish investor, which ran into trouble as a result of the economic crisis in Argentina in 2002. The claim was brought under the Argentina-Spain BIT, and the respondent brought a counterclaim late in the proceedings (but technically timely, i.e. in its counter-memorial) alleging that the claimants, by failing to make the necessary investments required by the concession, had caused damage to Argentina and affected the human right to water and sanitation of the population. The tribunal asserted jurisdiction to hear the counterclaim on the basis of the broad formulation of the arbitration clause (Article $\mathrm{X}(1)$ ), which it saw as "completely neutral as to the identity of the claimant or respondent in an investment dispute arising 'between the parties".340 The tribunal rejected the claimant's argument that it could limit, through its own acceptance of the standing offer to arbitrate in the BIT, the scope of jurisdiction of the tribunal only to the claim but not the counterclaim. A key reason offered by the tribunal is that such argument would amount to asserting a right and ignoring the possibility for the counterparty to assert a similar right. ${ }^{341}$ This is consistent with the practice of the ICJ regarding reciprocity in the declarations of acceptance of the competence of the Court, ${ }^{342}$ although the tribunal did not refer to such practice. The tribunal also noted that in case of disagreement as to scope of consent under Article $\mathrm{X}$ of the BIT, "the appropriate conclusion would have been that no agreement had been concluded between the Parties". ${ }^{343}$ The tribunal further found a sufficient link between the claim and the counterclaim, ${ }^{344}$ a requirement that, in previous cases, had posed a major obstacle to counterclaims. ${ }^{345}$ Of note, the tribunal applied, for jurisdictional purposes, the prima facie test for the allegations of fact forming the basis of the claim and, on this basis, it rejected the argument that counterclaims based on the violation of human rights were excluded from the treaty. ${ }^{346}$ The explanation for this assertion of jurisdiction is provided later, in the

\footnotetext{
338 Perenco Ecuador Ltd v. The Republic of Ecuador and Empresa Estatal Petróleos del Ecuador (Petroecuador), ICSID Case No. ARB/08/6, Interim Decision on the Environmental Counterclaim (11 August 2015) [Perenco v. Ecuador - Counterclaim].

339 Burlington Resources Inc. v. Republic of Ecuador, ICSID Case ARB/08/5, Decision on Counterclaims (7 February 2017) [Burlington v. Ecuador - Counterclaim].

340 Urbaser v. Argentina, para. $1143 . \quad 341$ Urbaser v. Argentina, para. 1146.

342 Cameroon v. Nigeria, para. 43. 343 Urbaser v. Argentina, para. 1147.

344 Urbaser v. Argentina, para. 1151.

345 Saluka Investments B.V. v. The Czech Republic, UNCITRAL Rules, Decision on Jurisdiction over the Czech Republic's Counterclaim (7 May 2004); Sergei Paushok, CJSC Golden East Company and CJSC Vostokneftegaz Company v. The Government of Mongolia, UNCITRAL Rules, Award on Jurisdiction and Liability (28 April 2011), paras. 684-99; Spyridon Roussalis v. Romania, ICSID Case No. ARB/06/1, Award (7 December 2011), paras. 859-76.

346 Urbaser v. Argentina, paras. 1153-4.
} 
tribunal's discussion of the applicable law and of the framing of the counterclaim. Both issues are significant for the present discussion.

101. Regarding the applicable law, the tribunal dealt with this matter at the level of the merits of the counterclaim, although the applicable law clause informed its understanding of the scope of the arbitration clause. The starting point of the analysis was the rejection of a theoretical argument made by the investor, namely that the asymmetric nature of BITs excluded any rights of the host State and therefore any obligations of investors. The tribunal observed that there was no textual basis for this argument in the BIT and, in all events, there were clear rights of the host State provided in the treaty, such as the right to bring a counterclaim against an investor. ${ }^{347}$ More importantly, the tribunal noted that the treaty could not be construed in isolation from the broader body of international law because the applicable law clause (Article X(5)) specifically referred, in addition to the application of the treaty itself, to the application of other treaties in force between the parties, the host State's domestic law, and "general principles of international law":

As far as recourse to the "general principles of international law" is concerned, such reference would be meaningless if the position would be retained that the BIT is to be construed as an isolated set of rules of international law for the sole purpose of protecting investments through rights exclusively granted to investors. ${ }^{348}$

Thereafter, the tribunal made two observations which have attracted much interest, namely that:

On a preliminary level, the Tribunal is reluctant to share Claimants' principled position that guaranteeing the human right to water is a duty that may be borne solely by the State, and never borne also by private companies like the Claimants. When extended to human rights in general, this would mean that private parties have no commitment or obligation for compliance in relation to human rights, which are on the States' charge exclusively ... A principle may be invoked in this regard according to which corporations are by nature not able to be subjects of international law and therefore not capable of holding obligations as if they would be participants in the State-to-State relations governed by international law. While such principle had its importance in the past, it has lost its impact and relevance in similar terms and conditions as this applies to individuals. ${ }^{349}$

To ground the possibility that a multinational company may be bound by human rights, the tribunal referred to some assertions of the right to water and sanitation, ${ }^{350}$ the underlying rights found in the International Covenant on

\footnotetext{
347 Urbaser v. Argentina, paras. 1183-4.

349 Urbaser v. Argentina, paras. 1193-4.

348 Urbaser v. Argentina, para. 1189.

350 Committee on Economic, Social and Cultural Rights, General Comment No. 15 (2002), The Right to Water (Arts. 11 and 12 of the International Covenant on Economic, Social and Cultural Rights), 26 November 2002, UN ESCOR Doc. E/C.12/2002/11; Resolution A/64/292, "The Human Right to Water and Sanitation", 28 July 2010, UN Doc. A/64/L.63/Rev.1. The tribunal further referred, as evidence of the proposition that companies can be subject to obligations arising from human rights, the International Labour Organization's Tripartite Declaration of Principles concerning Multinational Enterprises and Social Policy, 4th edition (2006) [MNE Declaration], principle 8 (stating that "All
} 
Economic, Social and Cultural Rights (ICESCR) ${ }^{351}$ and certain provisions included in this Covenant and in the Universal Declaration of Human Rights to the effect that human rights instruments must not "be interpreted as implying for any State, group or person any right to engage in any activity or to perform any act aimed at the destruction of any of the rights or freedoms recognized herein, or at their limitation to a greater extent than is provided for in the [relevant instrument]". ${ }^{352}$ It is true that States have an obligation to protect individuals from the deprivation of their human rights by the action of a third party, including companies, but that is an obligation of States. The key consideration when moving the duty-bearing status down the line to providers, such as utilities, is the actual power with which they are effectively entrusted. In the end, the tribunal concluded that the existence of the human right to water and sanitation in international law and its relevance for the conduct of an investor were mediated by the regulatory framework governing the concession contract. Specifically, claimants were bound by such framework, not by the human right to water arising from international law, even if the ultimate aim of the concession was to implement the obligations arising from that right. ${ }^{353}$

102. The framing of the counterclaim became an obstacle on this point. The respondent sought to derive damages from the violation of human rights law, although the allegation was that the investor had failed to invest sufficient resources to expand the water and sewer network. The tribunal had accepted prima facie, for jurisdictional purposes, the facts underlying the counterclaim but, when assessing them on the merits, it rejected the allegations of the respondent. The framing in terms of human rights made it particularly complex for the respondent to show the failure of the investor. The focus was on the lack of investment in the expansion of the network. That was an obligation under the concession, but at the level of international human rights law, the obligation to respect, protect and fulfil human rights rests on States. A concession may serve to comply with the obligation to "fulfil", and appropriate regulation of a private utility may serve to comply with the obligation to "protect" (from deprivation of the human right as a result of the misconduct of the utility). But the duty-bearer of the human rights held by each affected person remains the State. An alternative framing of the counterclaim would have been to state that (i) the State has the obligation to respect and, particularly, protect and fulfil, (ii) in order to fulfil the human right to water, the State relies on a private concessionaire, (iii) a key aspect of the concession - in view of the State's human rights obligations - is investment in the expansion of the network, (iv) to protect the human rights of individuals from deprivation by third parties (i.e. the private utility), the State has to regulate it tightly, including holding it to its commitment of network expansion, (v) in the exercise of this duty arising from human rights, the State regulated the utility and eventually terminated the relationship, which had proven unfit for purpose, (vi) such termination, due to the

the Parties concerned by the MNE Declaration ... should respect the Universal Declaration of Human Rights (1948) and the corresponding International Covenants (1966)").

351 International Covenant on Economic, Social and Cultural Rights, 16 December 1966, 993 UNTS 3 [ICESCR], Articles 11 and 12; "Universal Declaration of Human Rights", 10 December 1948, 217 A (III) [UDHR], Article 25(1).

352 ICESCR, Article 5(1); UDHR, Article 30. 353 Urbaser v. Argentina, paras. 1206-10. 
fault of the investor, caused disruption, costs as well as unjust enrichment (the investor which obtained the benefit of the concession without performing its duties) for which the State claimed reparation. It is a complex argument, which failed, as far as one can understand from the decision, both at the level of framing and at the level of facts (with (v) and (vi) not sufficiently substantiated). A simpler approach in such situations would be to rely on domestic law to argue that the investor has violated the obligations set by the regulatory framework implementing the right to water.

103. Such was the approach followed for the environmental counterclaims ${ }^{354}$ brought by the respondent in Perenco v. Ecuador and Burlington v. Ecuador. Both cases concerned the environmental impact of oil extraction activities by the investors in the Ecuadorian part of the Amazon rainforest. In the first case, the tribunal assessed Perenco's liability for damage caused to the environment under both strict liability and fault-based liability regimes laid out in Ecuadorian law and incorporated into the applicable contractual framework. For present purposes, the two paragraphs with which the tribunal opens its analysis of the counterclaim are noteworthy:

Ecuador presented the environmental counterclaim on the basis that its experts had determined the existence of an "environmental catastrophe" in the two oil blocks situated in the country's Amazonian rainforest that had been worked by the consortium under Perenco's operatorship. Ecuador viewed this as an extremely serious matter deserving the most careful consideration by the Tribunal. On this point, the Tribunal cannot but agree. Proper environmental stewardship has assumed great importance in today's world. The Tribunal agrees that if a legal relationship between an investor and the State permits the filing of a claim by the State for environmental damage caused by the investor's activities and such a claim is substantiated, the State is entitled to full reparation in accordance with the requirements of the applicable law.

The Tribunal further recognises that a State has wide latitude under international law to prescribe and adjust its environmental laws, standards and policies in response to changing views and a deeper understanding of the risks posed by various activities, including those of extractive industries such as oilfields. All of this is beyond any serious dispute and the Tribunal enters into this phase of the proceeding mindful of the fundamental imperatives of the protection of the environment in Ecuador. ${ }^{355}$

A detailed and balanced analysis of the factual record followed, in which the tribunal, far from adopting a "green" stance, simply proceeded to a dispassionate assessment of domestic environmental law and of several instances suggesting negligence from the investor. The tribunal assertively applied environmental law and, in some cases, it resorted to specifically environmental techniques (such as reasoning that could be described as in dubio pro natura, ${ }^{356}$ the appointment of a tribunal's expert, ${ }^{357}$ encouragement given to the parties to reach a settlement on the amount of damage ${ }^{358}$ ) avoiding grand statements about environmental

\footnotetext{
354 The discussion of this point relies on Viñuales 2019.

355 Perenco v. Ecuador - Counterclaim, paras. 34-5 (emphasis added).

356 Perenco v. Ecuador - Counterclaim, paras. 361, 470-3 and 495.

357 Perenco v. Ecuador - Counterclaim, paras. 569, 587-8, 611(8) and (17).

358 Perenco v. Ecuador - Counterclaim, paras. 593 and 611(9).
} 
protection. A similar approach was followed by the tribunal in Burlington v. Ecuador, which, in a decision of over 400 pages, patiently and resolutely analysed Burlington's shortcomings in each one of the blocks and found it liable for environmental harm under Ecuadorian law. ${ }^{359}$ In both cases, environmental considerations are not integrated into the reasoning as an extraneous factor or as a component of a progressive view; they are simply addressed as a requirement of normal operations in the extractive industries. Environmental harm provides an ordinary basis to ground a counterclaim before an investment arbitration tribunal in application of domestic law.

\section{Defence Arguments Operating at the Level of Secondary Norms}

\subsection{Specific Excuses}

104. The term "specific excuses" is intended to convey two main features of the defence arguments organised under this heading, namely (i) the assumption that there is a prior breach to be "excused" (specifically, that the treaty and the specific primary norms are applicable, can be relied upon, and their assessment has led to the tentative conclusion that there is a breach), and (ii) that the grounds for "excusing" the breach are "specific" not only because of the exceptional nature of the situation (rather than the type of measures in question) but also of the availability of a "specific" clause addressing them in the applicable treaty. The latter point is the main difference between "specific" and "generally available" excuses, which are discussed in the next section. As noted earlier, clauses defining "specific excuses" can be distinguished from clauses excluding certain measures from the perimeter of the treaty (hence, operating at the level of the primary norm) by their focus on "situations". The relevant measures are not excluded from the perimeter of the treaty but their adoption is excused by the specific situation in which it occurs. Yet, this distinction is not always clearly expressed or fleshed out in the case law.

105. Two decisions reported in this volume, Sempra v. Argentina and Continental Casualty v. Argentina, touch upon emergency clauses in different ways. Both cases refer to the emergency clause (sometimes called "war clause") included in Article IV(3) of the applicable treaty, although it is only briefly discussed in Sempra. Moreover, as discussed earlier, in Sempra the tribunal conflated a nonprecluded measures clause (Article XI of the Argentina-US BIT) which exempts certain measures from the perimeter of the treaty with a specific excuse. In Continental Casualty, the tribunal distanced itself from the characterisation by the Ad Hoc Committee in Mitchell v. Congo of a provision in the Congo-US BIT similar to Article XI of the Argentina-US BIT. The Committee had concluded that the relevant clause was "a provision relating to the causes for exemption from liability or, in other words, a provision that precludes the wrongfulness of the behaviour of the State in certain exceptional circumstances, and not a provision that delimits that scope of application of the Treaty". ${ }^{360}$ Such characterisation was

\footnotetext{
359 Burlington v. Ecuador - Counterclaim.

360 Patrick Mitchell v. Democratic Republic of the Congo, ICSID Case No. ARB/99/7, Decision on the Application for Annulment of the Award (1 November 2006), para. 55.
} 
akin to that in Sempra. The tribunal in Continental Casualty stated that it "[did] not share" such a position and followed instead the view of the Ad Hoc Committee in $C M S$ v. Argentina ${ }^{361}$ discussed earlier in this study. Yet, given the divergent views adopted in respect of Article XI of the Argentina-US BIT and the now prevailing view that it constitutes a non-precluded measures clause, these cases are not a sufficient basis to study the operation of emergency clauses or, more generally, of specific excuses.

\section{EXCEPTIONS}

106. It is useful to start by providing some examples of specific excuses in order to better understand the difference between a carve-out and a specific excuse. In Canadian treaty practice, including the NAFTA (Article 1106(6)), one finds clauses formulated in a manner similar or close to Article XX of the GATT:

1. Subject to the requirement that such measures are not applied in a manner that would constitute arbitrary or unjustifiable discrimination between investments or between investors, or a disguised restriction on international trade or investment, nothing in this Agreement shall be construed to prevent a Party from adopting or enforcing measures necessary:

(a) to protect human, animal or plant life or health;

(b) to ensure compliance with laws and regulations that are not inconsistent with the provisions of this Agreement; or

(c) for the conservation of living or non-living exhaustible natural resources. ${ }^{362}$

The drafting of the clause ("nothing in this Agreement shall be construed to prevent") is similar to that of non-precluded measures and the approach followed by investment tribunals in that context (exclusion of jurisdiction or absence of liability) would normally remain relevant. Yet, such clauses are drafted following the wording of Article XX of the GATT. In WTO practice, such general exception clauses are construed as excusing conduct that has been found in breach of primary norms (typically Articles I, III and XI of the GATT). ${ }^{363}$ It is therefore unclear how they would operate in investment arbitration. The lack of settled practice on this matter makes both positions plausible.

\section{EMERGENCY CLAUSES (WAR AND EXTENDED WAR CLAUSES)}

107. Another type of specific excuse for which there is some arbitral practice are the so-called "war clauses". Commentators usually distinguish between "war clauses", which require non-discrimination in the compensation of losses suffered as a result of armed conflict (only if such compensation is provided to others), and

\footnotetext{
361 Continental Casualty v. Argentina, para. 167, footnote 242.

362 Reproduced in A. Newcombe, "General Exceptions in International Investment Agreements", in M.-C. Cordonnier Segger, M. W. Gehring, A. Newcombe (eds), Sustainable Development in World Investment Law (Alphen aan den Rijn: Wolters Kluwer, 2011) pp. 355-70, at 359.

363 See e.g. United States - Standards for Reformulated and Conventional Gasoline, WT/DS2/AB/R (29 April 1996), page 23; European Communities - Measures Affecting Asbestos and AsbestosContaining Products, WT/DS135/AB/R (12 March 2001), para. 115; Thailand - Customs and Fiscal Measures on Cigarettes from the Philippines, WT/DS371/AB/R (17 June 2011), para. 173.
} 
"extended war clauses", which in addition to non-discrimination require compensation if some conditions are met. ${ }^{364}$ One example of a simple war clause is Article IV(3) of the Argentina-US BIT, which provides that:

Nationals or companies of either Party whose investments suffer losses in the territory of the other Party owing to war or other armed conflict, revolution, state of national emergency, insurrection, civil disturbance or other similar events shall be accorded treatment by such other Party no less favorable than that accorded to its own nationals or companies or to nationals or companies of any third country, whichever is the more favorable treatment, as regards any measures it adopts in relation to such losses.

This clause was interpreted in Sempra v. Argentina as harmonising the treatment of investors who suffer losses due to the emergencies listed in the clause, but the tribunal dismissed the possibility that this clause may derogate from treaty rights or exclude wrongfulness, liability or compensation. ${ }^{365}$ This is not the only possible reading of the clause. It could also be interpreted as an understanding that such losses are only compensable if the host State compensates its own nationals or nationals of third countries. Non-discrimination would be ensured both if no one is compensated and if all the parties who have suffered losses are compensated in a non-discriminatory manner. So far, the latter understanding has not permeated the investment case law. ${ }^{366}$

108. Regarding the so-called "extended war clauses", one example is provided by Article 4 of the Sri Lanka-UK BIT. This Article, entitled "Compensation for losses", reads as follows:

(1) Nationals or companies of one Contracting Party whose investments in the territory of the other Contracting Party suffer losses owing to war or other armed conflict, revolution, a state of national emergency, revolt, insurrection or riot in the territory of the latter Contracting Party shall be accorded by the latter Contracting Party treatment, as regards restitution, indemnification, compensation or other settlement, no less favourable than that which the latter Contracting Party accords to its own nationals or companies or to nationals or companies of any third State.

(2) Without prejudice to paragraph (1) of this Article, nationals and companies of one Contracting Party who in any of the situations referred to in that paragraph suffer losses in the territory of the other Contracting Party resulting from:

(a) requisitioning of their property by its forces or authorities, or

(b) destruction of their property by its forces or authorities which was not caused in combat action or was not required by the necessity of the situation,

shall be accorded restitution or adequate compensation. Resulting payments shall be freely transferable.

Extended war clauses (the extension from the basic war clause in paragraph (1) is paragraph (2)) can be further subdivided into two types of clauses: compensation

\footnotetext{
364 See C. Schreuer, "War and Peace in International Investment Law" (2019) 10 European Yearbook of International Economic Law 1-21.

365 Sempra v. Argentina, paras. 362-3.

366 See American Manufacturing \& Trading, Inc. v. Republic of Zaire, ICSID Case No. ARB/93/1, Award (21 February 1997) [AMT v. Zaire], para. 6.24; CMS v. Argentina-Award, para. 375.
} 
of the losses suffered from the requisitioning of the investor's property by the host State forces or authorities ("requisition clause") and potential compensation for (i) the destruction of such property if (ii) such destruction was caused by the host State's forces or authorities, (iii) outside combat action, and (iv) beyond what is required by the necessity of the situation ("destruction clause").

109. In case of requisitioning, which is assimilated to expropriation, "restitution" or "adequate compensation" are due if the investor establishes that its property was requisitioned by the organs of the host State without compensation. The foundation for this obligation of compensation is the unjust enrichment of the State which requisitions the property. This is why, when the loss is not caused by requisitioning (and hence there is no unjust enrichment), the State is not bound to compensate unless certain conditions - which embody the faulty behaviour of the State - are met or, alternatively, if it pays compensation for loss to others, in which case the foundation of the obligation to pay compensation is non-discrimination. This is also why basic war clauses could be interpreted as excluding compensation unless there is unjust enrichment and/or discrimination and/or certain specific conditions (the destruction clause). But, as noted earlier, basic war clauses have so far been understood as mere non-discrimination standards without excusing effect.

110. The "destruction clause", with its four aforementioned requirements, operates as an excuse - due to the situation of emergency - to what otherwise constitutes a compensable breach of investment disciplines. The effect of the destruction clause is to make the destruction non-compensable because it is due to war or other emergency. This is not to say that the investment treaty becomes inapplicable or suspended due to the outbreak of armed conflict. Under the rules developed by the ILC relating to the effect of armed conflict on treaties, the matter is left to be addressed by the treaty itself, ${ }^{367}$ which does so precisely through war clauses. Thus, the treaty remains applicable but the armed conflict (or the emergency situation) changes the protective regime offered to the investor. Destruction of its property arising from this emergency situation will normally not lead to restitution or compensation unless it is due to the host State organs, outside combat action, and beyond the necessity of the situation. Alternatively, such reparation (restitution or compensation) will be due on the grounds of nondiscrimination, through the operation of the basic war clause, if the host State offers reparation (through restitution or compensation) to others affected by the same emergency.

111. Two additional considerations are worth noting. The first concerns the burden of proving the conditions for the "destruction clause". The tribunal in $A A P L$ v. Sri Lanka expressly allocated to the claimant the burden of proving these requirements, adding that this was a "heavy burden" to be discharged. ${ }^{368}$ This case is also useful because it sheds light on terms such as "combat action", which

\footnotetext{
367 International Law Commission, Draft Articles on the Effects of Armed Conflict on Treaties, 9 December 2011, GA Res. 66/ 99, UN Doc. A/RES/66/99, Articles 3 (no ipso facto suspension or termination) and 4 (what the treaty provides is controlling).

368 AAPL v. Sri Lanka, para. 58.
} 
according to the tribunal included not only regular military confrontation but also guerrilla warfare. ${ }^{369}$ The second consideration relates to the applicability of other primary norms when there is a war clause. Although the views are not entirely converging, most tribunals (or tribunal majorities) consider that war clauses do not affect the applicability of primary norms. ${ }^{370}$ The reasoning differs for basic war clauses and for extended war clauses. In the first case, tribunals emphasise that the "relative" protection offered by the non-discrimination standard is not meant to derogate from but to extend the operation of other primary norms. As noted by the tribunal in $C M S$ v. Argentina:

The plain meaning of the Article is to provide a floor treatment for the investor in the context of the measures adopted in respect of the losses suffered in the emergency, not different from that applied to nationals or other foreign investors. The Article does not derogate from the Treaty rights but rather ensures that any measures directed at offsetting or minimizing losses will be applied in a non-discriminatory manner. ${ }^{371}$

The tribunal in $A A P L$ v. Sri Lanka similarly interpreted Article 4(1) of the Sri Lanka-UK BIT as applying together with the full protection and security clause in Article 2(2) of the treaty. ${ }^{372}$ The same reasoning applies to "requisition clauses" even though they are seen as part of extended war clauses. As regards "destruction clauses", the reasoning is that the clause only excuses a violation of an otherwise applicable primary norm (e.g. full protection and security) with the effect that compensation may be excluded unless certain conditions are met. Thus, whereas basic war clauses as well as the requisition clause apply together with (at the same stage of the analysis as) other primary norms, destruction clauses presuppose a breach that may be excused.

\subsection{Generally Available Excuses}

112. As noted in the previous section, generally available excuses are characterised by (i) the prior existence of a breach but for the excuse, and (ii) the "general availability" of the excuse, i.e. the lack of need for a specific clause in the applicable treaty or contract. Normally, generally available excuses concern a range of "situations" that are commonly understood to excuse behaviour which would otherwise be unlawful. An additional source of complexity stems from the inclusion, under this heading, of defence arguments arising from international law (countermeasures and necessity), domestic law (unforeseeability or théorie de l'imprévision) or both (force majeure, with a different characterisation depending on the legal origin). This complexity is a result of the application, in international investment arbitration, of both international and domestic law (including contracts subject to a domestic law often chosen by the parties).

\footnotetext{
369 AAPL v. Sri Lanka, para. 61.

370 AAPL v. Sri Lanka, paras. 66-7; AMT v. Zaire, paras. 6.04-6.11; CMS v. Argentina - Award, para. 375; Sempra v. Argentina, paras. 362-3. See also Way2B v. Libya, ICC Arbitration, Award (24 May 2018) (this decision has not been published but its content is known indirectly through L. E. Peterson, “Way $2 B$ v. Libya Tribunal finds that BIT's war-losses clause does not exclude operation of other BIT protections (including full protection \& security), but foreign investor fails to meet evidentiary burdens", International Arbitration Reporter (8 January 2019)).

371 CMS v. Argentina - Award, para. 375. $\quad 372$ AAPL v. Sri Lanka, para. 70.
} 


\section{NECESSITY 373}

113. Despite considerable controversy throughout the long period of its codification, ${ }^{374}$ the customary basis of the necessity defence, as defined in Article 25 of the ILC Articles on State Responsibility, ${ }^{375}$ is nowadays widely acknowledged. ${ }^{376}$ According to this provision:

1. Necessity may not be invoked by a State as a ground for precluding the wrongfulness of an act not in conformity with an international obligation of that State unless the act:

(a) is the only way for the State to safeguard an essential interest against a grave and imminent peril; and

(b) does not seriously impair an essential interest of the State or States towards which the obligation exists, or of the international community as a whole.

2. In any case, necessity may not be invoked by a State as a ground for precluding wrongfulness if:

(a) the international obligation in question excludes the possibility of invoking necessity; or

(b) the State has contributed to the situation of necessity.

114. The operation of the necessity defence as a generally available excuse which only comes into play if a breach of a primary norm has been detected is, by now, well established. As noted by the tribunal in in Metalpar v. Argentina:

For the purposes of this proceeding, as explained below, it is not necessary to clarify this matter due to the fact that, as will be shown further ahead, Claimants did not prove that their investments in the Argentine Republic were adversely affected by the actions taken by the Argentine Government, which would make it pointless to decide whether the measures taken by Argentina and challenged by Claimants, were executed due to there being a "state of necessity," which would extinguish the liability that could be attributed to Respondent. ${ }^{377}$

115. This provision has been addressed in a significant number of investment disputes, mostly arising from the 2002 economic crisis in Argentina, ${ }^{378}$ but also

373 The discussion in this section relies on Viñuales 2012 and 2014.

374 S. Heathcote, "Circumstances Precluding Wrongfulness in the ILC Artices on State Responsibility: Necessity", in J. Crawford et al. (eds.), The Law of International Responsibility (Oxford University Press, 2010), pp. 491-501, at 492-4.

375 Responsibility of States for Internationally Wrongful Acts, G.A. Res. 56/83, UN Doc. A/RES/56/

83, 12 December 2001 [ILC Articles on State Responsibility].

376 Gabčíkovo-Nagymaros Project (Hungary/Slovakia), I.C.J. Reports 1997, p. 7 [GabčíkovoNagymaros], paras. 50-2 (referring to Article 33 of the previous draft on State responsibility); Legal Consequences of the Construction of a Wall in the Occupied Palestinian Territory, Advisory Opinion, I.C.J. Reports 2004, p. 136, at para. 140 [Wall Opinion]; CMS v. Argentina, para. 315.

377 Metalpar v. Argentine Republic, ICSID Case No. ARB/03/5, Award (6 June 2008) [Metalpar v. Argentina], para. 211.

378 See CMS v. Argentina - Award, paras. 316-31; CMS v. Argentina - Annulment, paras. 137-50; $L G \& E$ v. Argentina, paras. 201-61; Enron v. Argentina - Award, paras. 314-42; Enron v. ArgentinaAnnulment, paras. 396-417; Sempra v. Argentina, paras. 333-55; Sempra v. Argentina - Annulment, paras. 159-223; Continental Casualty v. Argentina, paras. 160-99, 231-6; Suez. v. Argentina - 03/17, paras. 235-43; Suez, Sociedad General de Aguas de Barcelona, S.A. and Vivendi Universal, S.A. 
from other contexts such as land redistribution in Zimbabwe. ${ }^{379}$ Different features of these cases are noteworthy. First, all the cases without exception recognise the customary nature of the necessity defence codified in Article 25 of the ILC Articles on State Responsibility. ${ }^{380}$ Secondly, there is a divide between cases where a plea of necessity was rejected and cases where it was admitted, despite the similarity of the factual configuration (the Argentine economic and social crisis of 2001-3). Three of the cases where the defence was rejected have been severely criticised at the level of annulment proceedings, ${ }^{381}$ with two cases annulled on this point. ${ }^{382}$ Thirdly, these cases address in some detail the content and interpretation of the customary necessity defence. Some useful insights can be therefore derived from such practice for future investment disputes as well as for general international law.

116. The rule in Article 25 involves five cumulative requirements to be established by the party alleging the defence, ${ }^{383}$ which are preceded by a clear statement that the availability of the defence is deemed to be exceptional ("[n]ecessity may not be invoked ... unless"). The five conditions set in customary international law are: (i) the conduct of the State in breach of the norm is "the only way", (ii) to safeguard an "essential interest", (iii) against a "grave and imminent peril"; 384 (iv) which the State invoking necessity has not "contributed to" create; and (v) the act must not seriously impair an overriding interest (an essential interest) of the beneficiaries of the obligation or the international community as a whole. Article 25(2)(a) also mentions the requirement that the obligation violated must not exclude the possibility of invoking necessity. This could be seen as falling under condition ( $v$ ) to the extent that the obligation in question may be a peremptory norm or a norm which is part of an incompressible core (e.g. certain prohibitions arising from international humanitarian law and human rights). ${ }^{385}$ The most authoritative discussion of these conditions remains the case concerning the Gabčíkovo-Nagymaros Project (Hungary/Slovakia) decided by the ICJ. ${ }^{386}$ But the investment case law makes some useful additions.

117. One such addition concerns the implications of the exceptional character of necessity. Such character might suggest the requirements must be interpreted restrictively. ${ }^{387}$ Restrictive interpretation in this context would operate as if a

v. Argentine Republic, ICSID Case No. ARB/03/19, Decision on liability (31 July 2010) [Suez v. Argentina - 03/19], paras. 257-71.

379 Von Pezold v. Zimbabwe, paras. 624-68. 380 See note 386.

$381 C M S$ v. Argentina - Annulment, para. 146; Enron v. Argentina - Annulment, paras. 368, 371-5, 393; Sempra v. Argentina - Annulment, paras. 159, 205-7, 218.

382 Enron v. Argentina - Annulment, para. 395; Sempra v. Argentina - Annulment, para. 159.

383 See Gabčíkovo-Nagymaros, para. 54 ("The Hungarian argument on the state of necessity could not convince the Court unless it was at least proven that a real, 'grave' and 'imminent' 'peril' existed in 1989 and that the measures taken by Hungary were the only possible response to it").

384 Gabčíkovo-Nagymaros, para. 52. 385 Wall Opinion, paras. 135, 136 and 140.

386 Gabčíkovo-Nagymaros, paras. 49-58. See also the discussion in Von Pezold v. Zimbabwe, paras. 624-68.

387 Canfor Corporation, v. United States of America and Terminal Forest Products Ltd v. United States of America, NAFTA (UNCITRAL Rules), Decision on Preliminary Question (6 June 2006) [Canfor v. United States], para. 187; CMS v. Argentina - Award, para. 317 ("or are loosely applied"); Enron v. Argentina - Award, para. 331. 
higher standard of proof were imposed on the respondent to establish each and every requirement for the availability of the necessity defence. Given the stringency of the requirements, this would amount not only to require five cumulative conditions but also to make each condition extremely difficult to meet. Perhaps the most salient example is given by the divergent treatment of the condition set out in paragraph 1(a) ("the only way ... to safeguard an essential interest") of Article 25 of the ILC Articles in different awards. Does "the only way" mean the only realistically available way or the only way out of a set including theoretical measures or measures that the State has never applied or has no experience in handling? In $C M S$ v. Argentina the tribunal opted for the second interpretation considering as a possible option the opinion of some expert economists that full scale "dollarisation" of the economy would have been an option. ${ }^{388}$ Can a State be realistically expected to take, in the middle of a crisis, a measure as wide-ranging and risky as the adoption of the currency of another State? Aside from the fact that such a measure would entail the surrendering of monetary policy (and therefore encroach on monetary sovereignty), it is a very complex measure to adopt. In theory, there are always "options". Placing such a high threshold for this condition to be met amounts to depriving the necessity defence of any practical operation. ${ }^{389}$ This was noted by the Ad Hoc Committee in Enron v. Argentina, which, addressing the way in which the Enron tribunal had dealt with this condition, concluded that the tribunal had interpreted this condition too literally without inquiring inter alia into the reasonableness or the effectiveness of the measure. ${ }^{390}$ Restrictively interpreting each requirement of the already exacting cumulative test of the necessity defence is therefore not an innocuous step. And there is no clear basis for doing so. The restrictive character of the necessity defence is ensured by the cumulative requirements set to its availability ${ }^{391}$ and not in the restrictive interpretation of each of those requirements.

118. Another contribution concerns the nature of the protected interest at stake in a plea of necessity. The basic answer is that only "essential" interests can satisfy requirement (ii) of the necessity defence. In Gabčlkovo-Nagymaros, the ICJ had expressly admitted that:

the concerns expressed by Hungary for its natural environment in the region affected by the Gabčíkovo-Nagymaros Project related to an "essential interest" of that State, within the meaning given to that expression in Article 33 of the Draft of the International Law Commission. ${ }^{392}$

Hungary had raised concerns relating inter alia to the potential effects of the construction projects contemplated in a treaty of 1977 on the aquifer providing Budapest with fresh water. Investment tribunals have further clarified which other interests of the host State may qualify as "essential" for necessity purposes. In Suez

\footnotetext{
388 CMS v. Argentina - Award, paras. 323-4. See also Enron v. Argentina - Award, para. 308; Sempra v. Argentina, paras. $350-1$.

389 See M. Waibel, "Two Worlds of Necessity in ICSID Arbitration: CMS and LG\&E" (2007) 20 Leiden Journal of International Law 637.

390 Enron v. Argentina - Annulment, paras. 366-78. 391 Gabčíkovo-Nagymaros, para. 51 in fine.

392 Gabčíkovo-Nagymaros, para. 53.
} 
v. Argentina, two cases concerning water distribution in Argentina, the tribunals acknowledged that " $[t]$ he provision of water and sewage services ... certainly was vital to the health and well-being of [the population] and was therefore an essential interest of the Argentine State", 393 although they rejected the defence on other grounds. In Von Pezold v. Zimbabwe, the tribunal rejected the argument that a political manifestation, although very important, threatened an essential interest of the State rather than of the ruling party. It noted, in this regard, that "it cannot automatically follow that a threat to the existence of a political party is a threat to the existence of a State and therefore an essential interest that is necessary to protect at all costs". ${ }^{394}$ This conclusion appears correct on the facts of the case but not as a general rule. An essential interest of the State does not need to be related to its "survival". The correct position remains the one expressed by the ICJ in Gabčikovo-Nagymaros, which is encompassing enough to include interests unrelated to the survival of the State.

119. The dissociation of the interest of the ruling party and that of the State in Von Pezold was also important for the tribunal to conclude that the land occupations, although possibly an imminent threat to the party, did not threaten the State as such. ${ }^{395}$ The hard decision faced by the government stemmed from the fact that the demonstrators were part of the initial political support base of the ruling party, which the latter sought to appease through measures which exacerbated racial divisions. To the argument that such measures were the "only way" to deal with the imminent threat because the demonstrators could not be opposed or resisted, the tribunal observed:

The Respondent's contention that political and racial movements should not be addressed because of their volatile nature cannot be accepted. The purpose of any State, and particularly its police force, is to maintain order in spite of such instabilities rather than stepping back and allowing the citizenry to devolve into anarchy. The Tribunal further notes that there seemed to be a promotion of such racial and political overtones, instead of an attempt to subdue them. ${ }^{396}$

120. The latter point is also relevant in connection with the requirement that the State must not have contributed to the situation of necessity. What amounts to "contribution" is a fact-intensive inquiry. In Von Pezold, the tribunal concluded that there was clear evidence that the government assisted and supported the occupation of the lands by the demonstrators to an extent that Zimbabwe had "not only contributed to its economic decline, but was also one of the primary instigators of the situation that [had given] rise to the imminent peril". 397 Such contribution is sufficiently clear cut. In Gabčíkovo-Nagymaros, the ICJ had similarly concluded that inconsistency in the behaviour of Hungary with respect to the pursuit of the works precluded it from relying on the necessity defence. ${ }^{398}$ In Sempra v. Argentina, the parties argued extensively on whether the 2002 economic crisis had been precipitated by endogenous or exogenous factors. The tribunal

\footnotetext{
393 Suez v. Argentina - 03/17, para. 238; Suez v. Argentina -03/19, para. 260.

394 Von Pezold v. Zimbabwe, para. 631. 395 Von Pezold v. Zimbabwe, para. 636.

396 Von Pezold v. Zimbabwe, para. 642. 397 Von Pezold v. Zimbabwe, para. 667.

398 Gabčíkovo-Nagymaros, para. 57.
} 
concluded that both factors were at play 399 and that, although the "state of affairs [had] not been the making of a particular administration ... the State must answer for it as a whole". ${ }^{400}$ Whereas the principle of the continuity of the State in this context is sound, this conclusion may have the consequence that the necessity defence could never operate in economic crises or even in war or civil strife because there is always a combination of factors at play.

121. A final issue concerns the effects of the necessity defence and, specifically, whether the excusing effect of necessity precludes any form of compensation. Article 27 of the ILC Articles on State Responsibility leaves open the possibility that a State may have an obligation to pay damages despite having availed itself of a circumstance precluding wrongfulness. According to this provision " $[\mathrm{t}] \mathrm{he}$ invocation of a circumstance precluding wrongfulness in accordance with this chapter is without prejudice to: ... (b) the question of compensation for any material loss caused by the act in question". ${ }^{401}$ Shortly before the adoption of this provision in its final version, the then special rapporteur on this topic, Professor James Crawford, wrote that conduct covered by the necessity defence is "in some sense wrongful, although there may be an excuse for it" and referred, in this connection, to "the possibility of compensation in cases of necessity". 402 This comment echoes an idea already present in the Gabčíkovo-Nagymaros case, where the Court had pointed out that Hungary had "expressly acknowledged that, in any event, ... a state of necessity would not exempt it from its duty to compensate its partner". 403 Yet, this idea was not clearly couched in the final draft of the ILC Articles, which indicates that it was not viewed as an entirely accurate reflection of customary law. Thus, while it seems clear that necessity, as a customary defence, does not preclude compensation, it is also clear that no obligation to compensate arises from customary law. In practice, some form of compensation would seem fair because a State acting under necessity is prioritising its own interests over those of other States. But in the case of investors based in the territory of the State concerned, it would also seem fair that all those that find themselves in the same situation when the crisis hits share the burden. In other words, if the tribunal concludes that compensation must be paid to the investor, it would seem unfair to use the standards of compensation as in cases of an unexcused breach. A possible distinction would be between cases in which the excused measures have led to an enrichment of the State, in which compensation would be due on that specific basis, and other cases where no such enrichment has taken place. In the latter hypothesis, fairness would require that those who have been most directly affected by the excused measures be compensated for the extra burden they carry (as compared to those adversely but not specifically affected). What should be excluded is compensation as if there was no excuse.

\footnotetext{
399 Sempra v. Argentina, para. 353. 400 Sempra v. Argentina, para. 354.

401 ILC Articles on State Responsibility, Article 27.

402 J. Crawford, "Revising the Draft Articles on State Responsibility" (1999) 10 European Journal of International Law 435, at 444.

403 Gabčíkovo-Nagymaros, para. 48.
} 


\section{COUNTERMEASURES ${ }^{404}$}

122. Aside from the necessity defence, other customary defences arising from the law on State responsibility for internationally wrongful acts may also have a bearing on investment disputes. Such is the case of breaches of international law excused under the doctrine of countermeasures. Article 22 of the ILC Articles codifies this circumstance precluding wrongfulness in the following terms:

The wrongfulness of an act of a State not in conformity with an international obligation towards another State is precluded if and to the extent that the act constitutes a countermeasure taken against the latter State in accordance with chapter II of Part Three.

The most relevant provisions of chapter II of Part Three are Articles 49 and 50, which define the object and limits of countermeasures. In at least three cases, ${ }^{405}$ the doctrine of countermeasures was raised in investment arbitration as a potential defence excusing measures with an adverse impact on investors. The three tribunals recognised the customary grounding of the countermeasures defence ${ }^{406}$ and discussed its relationship with the investment protection standards in Chapter 11 of the NAFTA. Two questions addressed in these cases concern: the extent to which the customary regime on countermeasures may be excluded by NAFTA's regulation of countermeasures; the operation of the customary regime depending on the conception of investment disciplines and treaties.

123. The first question was discussed in $A D M$ v. Mexico in connection with a tax on soft drinks and syrups using sweeteners other than sugar cane. The claimant, a producer of a sweetener (high fructose corn syrup or HFCS) affected by the measure, argued that the tax was in breach of the protections afforded to investors by Chapter 11 of the NAFTA. The respondent referred, as part of its defence, to the customary regime on countermeasures arguing that the tax was a legitimate response to a breach of the NAFTA by the United States, the investor's home State. The tribunal analysed the question whether the NAFTA contained a specific regime on countermeasures that would operate as a lex specialis excluding the application of the customary regime. It reasoned that, despite a reference in Article 2019 (Chapter 20) of the NAFTA to countermeasures, Chapter 11 neither authorised nor prohibited the use of countermeasures. As a result, the customary regime on countermeasures remained applicable:

Outside Article 2019, the NAFTA makes no express provision for countermeasures. Accordingly, the default regime under customary international law applies to the present situation ... The Tribunal therefore agrees with Respondent that countermeasures may serve as a defence under a Chapter Eleven case, as this is a matter not specifically addressed in Chapter Eleven, but valid under customary international law if certain conditions are met. ${ }^{407}$

\footnotetext{
404 This section relies on Viñuales 2013.

405 Archer Daniels Midland Company and Tate \& Lyle Ingredients Americas, Inc. v. United Mexican States, ICSID Case No. ARB(AF)/04/5, Award (21 November 2007) [ADM v. Mexico]; Corn Products International Inc. v. United Mexican States, ICSID Case No. ARB(AF)/04/1, Decision on Responsibility (15 January 2008) [Corn Products v. Mexico]; and Cargill v. Mexico.

406 ADM v. Mexico, paras. 125-6; Corn Products v. Mexico, para. 145; Cargill v. Mexico, para. 420.

407 ADM v. Mexico, paras. 120-3.
} 
However, the tribunal concluded that the requirements for the adoption of countermeasures were not fully met.

124. A different but related question is whether the customary regime on countermeasures is precluded from operating as a defence against a claim for breach of Chapter 11 because of the nature of the standards provided therein. In two other cases arising from the same tax imposed by Mexico and affecting producers of HFCS, the answer to this question differed from the position of the tribunal in $A D M$ v. Mexico. In Corn Products v. Mexico, the tribunal held that the doctrine of countermeasures concerned inter-State relations and, therefore, could not operate in an investor-State context:

The Tribunal has concluded, however, that the doctrine of countermeasures, devised in the context of relations between States, is not applicable to claims under Chapter XI of the NAFTA. Those claims are brought by investors, not by States. A central purpose of Chapter XI of the NAFTA was to remove such claims from the interState plane and to ensure that investors could assert rights directly against a host State. The Tribunal considers that, in the context of such a claim, there is no room for a defence based upon the alleged wrongdoing not of the claimant but of its State of nationality, which is not a party to the proceedings ... The Tribunal therefore concludes that the investor, such as CPI, has rights of its own under Chapter XI of the NAFTA. As such, it is a third party in any dispute between its own State and another NAFTA Party and a countermeasure taken by that other State against the State of nationality of the investor cannot deprive that investor of its rights. To revert to the two different examples given by the ILC in its Commentary on Article 49(1), this is a case involving the rights of a third party and not merely its interests. Mexico owed obligations to CPI under Chapter XI of NAFTA which were separate from the obligations it owed to the United States under the NAFTA as a whole. Even if the doctrine of countermeasures could operate to preclude the wrongfulness of the HFCS tax vis-à-vis the United States (and, for the reasons given below, the Tribunal makes no comment on that question), they cannot do so vis-à-vis CPI. ${ }^{408}$

The tribunal thus excluded the application of the customary doctrine of countermeasures not because of an argument based on the lex specialis principle but on the basis of the inapplicability of the doctrine with respect to third parties, including investors. This conclusion was based on the characterisation of investment protection standards not as State disciplines but as "rights". Conversely, the tribunal admitted that the doctrine of countermeasures could operate to shield the same measures vis-à-vis the United States.

125. One may ask, in this regard, whether a measure affecting foreign investors may under some circumstances be justified by the customary doctrine on countermeasures. The answer depends on how the situation is framed legally. The very same facts triggering an investment dispute may also (or alternatively) give rise to diplomatic protection, in which case the countermeasures defence would be available against the claim of the home State. The decision of the tribunal in Cargill v. Mexico, which is reported in this volume, addressed this question as follows: 
The Tribunal agrees with Respondent that if a State, through diplomatic protection, were to espouse the claims of its nationals damaged by a legitimate countermeasure, then that countermeasure would preclude the wrongfulness of the act that otherwise would have entailed State responsibility and the claims would be denied. In the case of diplomatic espousal, however, the claim is owned by the espousing State and the espousing State is the named party. Moreover, the operative paragraph of the resulting award reciting the decision of the tribunal names the espousing State, and not the national. ${ }^{409}$

Thus, according to Corn Products and Cargill, depending on whether investment protection standards are characterised as obligations owed to the other contracting State or to its investors, this customary defence would either apply or not. Interestingly, the $A D M$ tribunal referred to the specificity of Chapter 11 for a different purpose, namely to consider that Article 2019 (Chapter 20) could not operate as a lex specialis displacing the customary regime.

126. The two approaches are not contradictory. Recognising the difference between Chapters 11 and 20 of the NAFTA may be sufficient to conclude that a provision in Chapter 20 is not a lex specialis for claims under Chapter 11 and, yet, this is not to say that the customary regime is inapplicable to such claims. The question of the nature of investment disciplines is still debated. The distinction between obligations owed to other States and obligations owed to investors may not be a sufficient basis for excluding the operation of the doctrine of countermeasures. It would be difficult to argue that the exceptio non adimplenti contractus, ${ }^{410}$ the synallagmatic character of which is comparable to that of the doctrine of countermeasures, could not suspend the rights of foreign investors. Indeed, even if investors were deemed to have "rights" rather than to benefit from conditions negotiated by their home State, these rights are only due by virtue of their nationality, not of their inherent human dignity. They are commercial advantages granted by one State to the investor of another State because the overall deal with the home State makes such concessions advantageous as a reciprocal matter. The difference is very clearly perceived by human rights courts ${ }^{411}$ and by the ICJ. ${ }^{412}$ It is to be hoped that investment tribunals will also perceive it or, at least, will provide a more satisfactory explanation of why such "rights" should be immune to reciprocity considerations.

\section{THÉORIE DE L'IMPRÉVISION (UNFORESEEABILITY OR HARDSHIP)}

127. The excuse that may be derived from a fundamental change of the circumstances in which an agreement was concluded finds expression in the

\footnotetext{
409 Cargill v. Mexico, para. 424.

410 Article 60(1) of the VCLT provides that "[a] material breach of a bilateral treaty by one of the parties entitles the other to invoke the breach as a ground for terminating the treaty or suspending its operation in whole or in part". Paragraph 3(b) of this provision adds that "[t]he violation of a provision essential to the accomplishment of the object or purpose of the treaty". It is generally recognised that the basic principle underpinning this Article is part of general international law, although some details may have to be considered as progressive development.

411 Sawhoyamaxa Indigenous Community v. Paraguay, ICtHR Series C No. 146, Judgment (29 March 2006), paras. 136, 137 and 140.

412 Barcelona Traction, Light and Power Company, Limited, Judgment, I.C.J. Reports 1970, p. 3, para. 33.
} 
domestic law of many countries. This is the defence argument discussed in this section and characterised as a generally available excuse. In international law, the same logic underpins the customary rebus sic stantibus clause codified in Article 62 of the Vienna Convention on the Law of Treaties, ${ }^{413}$ but there is an important difference. Under Article 62, the fundamental change of circumstances allows for the withdrawal from a treaty or its termination. The primary norms provided for in the treaty become inapplicable, which is different from a situation where the primary norms remain applicable but their violation or less-than-full performance is excused.

128. In Enka v. Gabon, which is reported in this volume, the tribunal discussed the operation of the unforeseeability theory in the context of a settlement agreement relating to construction works between a Turkish investor and a Gabonese public agency. ${ }^{414}$ The respondent argued that, due to a decline in the price of oil as well as to the worsening of the economic and political conditions following a presidential election, there had been a fundamental change of circumstances which, under the applicable French administrative law, required a renegotiation of the contract. It referred, in this regard, to French public and private law (including Article 1195 of the French Civil Code, the UNIDROIT Principles on International Contracts and the Principles of European Contract Law). The tribunal noted at the outset that French administrative law could not apply to foreign public entities $^{415}$ and that Article 1195 was not applicable because the settlement agreement had been concluded prior to its entry into force. ${ }^{416}$ The latter conclusion is debatable as a choice-of-law clause in a contract does not refer to the state of the law at a specific point in time unless this is expressly mentioned in the clause. A choice-of-law clause necessarily refers to an evolving legal system, which in this case would have included subsequent amendments of French law (and hence Article 1195). In this specific case, however, the reasoning of the tribunal was justified by the fact that the French legal reform expressly contemplated that contracts entered into prior to the entry into force of Article 1195 would continue to be governed by the law in force as of the date of their conclusion. In all events, the tribunal analysed the requirements of the "unforeseeability theory" and concluded that its conditions were not met.

129. However, the tribunal did not provide a clear statement of this theory or of its conditions. For context, and given the respondent's reference to the UNIDROIT Principles of International Commercial Contracts, it may be useful to recall the relevant clause (Article 6.2.2) defining "hardship" (equated with the French théorie de l'imprévision in the introductory paragraph to this provision ${ }^{417}$ ):

There is hardship where the occurrence of events fundamentally alters the equilibrium of the contract either because the cost of a party's performance has increased or because the value of the performance a party receives has diminished and

413 Gabčíkovo-Nagymaros, para. 99.

414 Enka İnşaat ve Sanayi A.Ş. v. The Gabonese Republic, ICC Arbitration No. 22841/DDA, Final Award (14 September 2018) [Enka v. Gabon].

415 Enka v. Gabon, paras. 259-61. ${ }_{416}$ Enka v. Gabon, para. 262.

417 UNIDROIT, Principles of International Commercial Contracts (2010), at 211. 
(a) the events occur or become known to the disadvantaged party after the conclusion of the contract;

(b) the events could not reasonably have been taken into account by the disadvantaged party at the time of the conclusion of the contract;

(c) the events are beyond the control of the disadvantaged party; and

(d) the risk of the events was not assumed by the disadvantaged party.

The analysis of the tribunal focused on three aspects. First, the tribunal referred to the effects sought by the respondent, which essentially amounted to a payment moratorium. The tribunal noted that the unforeseeability theory cannot provide a basis for such an adjustment because the purpose of the theory is to re-establish the balance of the contract, which in casu had not changed. ${ }^{418}$ Secondly, there was ample evidence, including the respondent's admissions, that at the time the settlement agreement was concluded the oil price had already began its downward trajectory. Thus, the respondent could not now present its own negligence in anticipating the risks associated with the decline in the oil price as an unforeseeable event. ${ }^{419}$ Thirdly, and perhaps most interestingly, the tribunal observed that the very nature of the settlement agreement offered a difficult ground for the unforeseeability theory to operate because it was precisely through the negotiation of such an agreement that any imbalance in the initial bargain could have been adjusted by the parties. ${ }^{420}$

130. The théorie de l'imprévision was also addressed in some cases relating to the 2002 economic crisis in Argentina, due to its reception in Article 1198 of the Argentine Civil Code. ${ }^{421}$ In Sempra v. Argentina, the tribunal discussed the argument of the respondent according to which several concepts of domestic law, including the teoría de la imprevisión, entitled the respondent to rebalance contractual arrangements through an Emergency Law. ${ }^{422}$ The tribunal discussed all the concepts together, without clearly disentangling the requirements of each one of them. However, one aspect highlighted in Sempra is the need for any renegotiation of the contractual balance to be made either bilaterally, on the basis of an adjustment clause in the relevant agreement, or requested from and ordered by a judge, under the teoría de la imprevisión. ${ }^{423}$ Thus, the rebalancing cannot be made unilaterally.

131. The need to negotiate was also addressed by the Himpurna tribunal in the context of the 1997 financial crisis in Indonesia. The respondent, an Indonesian public entity which had undertaken to buy from the claimant a certain amount of electricity, invoked a fundamental change of circumstances (together with a force majeure event) to escape from its obligation. The tribunal agreed with the respondent that the doctrine of rebus sic stantibus could be considered as a corollary of the duty of good faith under the applicable (Dutch and Indonesian) law, but only on a highly exceptional basis precisely because good faith was also the foundation of pacta sunt servanda:

418 Enka v. Gabon, paras. 264-5. ${ }^{419}$ Enka v. Gabon, paras. 266-7.

420 Enka v. Gabon, para. 268. 421 See CMS v. Argentina - Award, paras. 221-5.

422 Sempra v. Argentina, paras. 241-69. ${ }^{423}$ Sempra v. Argentina, para. 258; CMS, para. 225. 
The Arbitral Tribunal is willing to accept that under Dutch as well as Indonesian law, there are situations in which the rule of good faith may operate to dissolve or transform contractual rights and obligations. On the other hand, it is quite clear that such a remedy is reserved for extreme cases. The fundamental principle of pacta sunt servanda forms the bedrock of the civil law of obligations everywhere. ${ }^{424}$

It rejected, however, the argument of the respondent on the merits of the case because:

if anyone refused to negotiate it was [the respondent], which has never responded to the claimant's offer, and never made a proposal of its own beyond unhelpfully asking the claimant to wait. The claimant had no duty to accept a suspension sine die of the [contract]; indeed, it had a right to treat [respondent]'s unresponsive muteness as a breach. [The respondent] is in no position to assail the claimant's good faith. ${ }^{425}$

On the issue of foreseeability of the financial crisis, the tribunal adopted a very demanding position, namely that the crisis could not be said to be unforeseeable because Indonesia had faced other comparable economic crises in the past. ${ }^{426}$ This may have been the appropriate conclusion on the facts of the dispute. The majority of the tribunal took into account the economic crisis to drastically reduce the compensation awarded to the claimant, but the characterisation of what is foreseeable or not would be deprived of any meaning if the tribunal's view were to be generalised. The exceptional events of the past do not make similar future events less exceptional. Otherwise, almost no major economic or political crisis could be deemed exceptional, as there are always precedents.

\section{FORCE MAJEURE}

132. Force majeure is an excuse both under the domestic law of most countries and under customary international law (Article 23 of the ILC Articles on State Responsibility). The relevant case reported in this volume, General Dynamics v. Libya, focuses on force majeure as a domestic law defence. Force majeure as well as distress were invoked in Von Pezold v. Zimbabwe as circumstances precluding wrongfulness but at a very late stage in the proceedings. ${ }^{427}$ For that reason, the tribunal deemed these arguments inadmissible. References to force majeure were also made in passing in Sempra v. Argentina, but not developed at any length, ${ }^{428}$ and in Devas v. India, as part of the factual analysis (a force majeure notice issued to terminate an agreement, which the tribunal analysed only under the provisions of the treaty). ${ }^{429}$

133. General Dynamics v. Libya concerned the performance of a contract signed between a UK company and Libyan defence authorities for the provision of military communication technology in armoured vehicles. The agreement was governed by Swiss law and the obligations were structured in seven "Milestones". Each involved the delivery of technology equipment and training, followed by payment, with the last Milestone involving the full conversion of the vehicles and

\footnotetext{
424 Himpurna case, para. 188. $\quad 425$ Himpurna case, para. $190 . \quad 426$ Himpurna case, para. 203.

427 Von Pezold v. Zimbabwe, paras. 35-43. $\quad 428$ Sempra v. Argentina, paras. 243, 246.

429 Devas v. India, paras. $282 \mathrm{ff}$.
} 
a final payment. In 2010, following completion of Milestones 5 and 6, the claimant sent invoices to the respondent. The latter, however, did not issue the acceptance certificates necessary under the contract for the claimant to be paid. In February 2011, with the outbreak of the Libyan civil war, the claimant sent a notice of force majeure concerning Milestone 7. The respondent argued before the tribunal that this notice suspended its own obligation to pay not only Milestone 7 but also Milestones 5 and 6 . The tribunal rejected this argument on the grounds that, under Swiss law, the respondent was already in default when the notice had been served. $^{430}$

134. However, the tribunal also considered the argument of the respondent according to which it had been prevented by force majeure (a clause included in Condition 22.1 of the contract), specifically (i) the outbreak of the civil war and foreign intervention, and (ii) the adoption of international sanctions (an assets freeze and an arms embargo), from making the payments corresponding to Milestones 5 and 6 . Condition 22.1 stated the following:

The Parties shall not be in default and will assume no liability or responsibility for consequences arising out of the interruption of their performance of this Contract by any external, absolute, invincible and/or unforeseen events such as ... civil commotion, riot, terrorism or the threat of terrorism, insurrection or hostilities whether or not declared, war... Such circumstances shall result in an excusable delay, and the affected Party shall notify the other Party in writing, by electronic means, or registered letter ... A delay resulting from any of the stated events ... shall suspend performance up to a period equal to the delay.

The tribunal concluded that the civil war and the foreign intervention could indeed constitute an event of force majeure, and that they had effectively impeded, while they lasted, the performance of the respondent's obligation relating to Milestones 5 and $6 .{ }^{431}$ One important factual element in this conclusion was the fact that the member of the Gaddafi family who oversaw the contract was heavily involved in the civil war and indeed killed in August 2011. And even if his involvement had not been as decisive, the "events in Libya were of a nature and intensity such as to interrupt the daily operation of the technical and administrative work of the Procurement Department". 432

135. Although the burden of proving an event of force majeure falls squarely, as a matter of principle, on the party invoking it (here the respondent), ${ }^{43}$ the fact that the claimant had also sent a force majeure notice and adduced evidence in this regard provided a solid evidentiary basis to the tribunal. ${ }^{434}$ This fact was also significant to exclude adverse effects from the lack of formal notice given by the respondent of the force majeure events, because the claimant was well aware of the situation. ${ }^{435}$ Eventually, the respondent was able to issue the acceptance certificates in October 2011, which for the tribunal further supported the view that before that date the force majeure event had indeed prevented the respondent from doing so.

\footnotetext{
430 General Dynamics v. Libya, paras. 233-44. ${ }_{431}^{431}$ General Dynamics v. Libya, paras. 250-1.

432 General Dynamics v. Libya, para. 255. 433 General Dynamics v. Libya, para. 273.

434 General Dynamics v. Libya, paras. 255-8. $\quad{ }^{435}$ General Dynamics v. Libya, paras. 278-80.
} 
136. The tribunal concluded that, although the respondent was already in default when the force majeure events took place, it could rely on this defence to excuse its non-performance for the duration of the events. ${ }^{436}$ It thus introduced a distinction between reliance on force majeure events - which effectively suspended the respondent's performance - and reliance on the force majeure notice issued by the claimant - which the tribunal had rejected earlier as a ground to suspend payment of Milestones 5 and 6 . The explanation given by the tribunal rested on the wording of Condition 22.1 of the contract, which was a lex specialis with respect to the Swiss Code of Obligations (Article 103). The exclusion or adaptation of the general clause through a contractual term (specifically allocating the risk for certain force majeure events to one party) was also recognised in the Himpurna case, where the tribunal noted that "[w]hile the Parties ... contemplated the possibility of future government action obstructing the performance of the ESC, they also agreed that the claimant alone would be able to rely on such acts as events of force majeure" ${ }^{437}$ Later in the award, the tribunal explained the rationale underlying the need to give effect to such contractual adjustments:

When stipulations like these appear in a long term agreement like the ESC, with respect to which it is obvious that the surrounding circumstances may change dramatically during the life of the contract, one can only conclude that the allocation of risk is intentional, indeed emphatic. ${ }^{438}$

137. Regarding the effects of the force majeure event, the tribunal in General Dynamics stated, pursuant to Condition 22.1, that the excusing effect meant that the respondent was not in default of the contract for all the duration of events. ${ }^{439}$ That had the implication that the notices of default and termination, under Article 107 of the Swiss Code of Obligations, sent by the claimant while the force majeure event lasted, were invalid and the termination was wrongful. The claimant could not therefore forgo subsequent performance and claim (higher) damages for nonperformance. ${ }^{40}$ In Himpurna, although the claimant was alone entitled to rely on the force majeure event under the contract terms, the tribunal nevertheless took into account the circumstances of the 1997 financial crisis in Indonesia to drastically reduce the damages (specifically the lost profits portion) sought to only a fraction of the amounts sought. ${ }^{441}$

\subsection{Quantum Reduction}

138. The difference between the defence arguments discussed in the previous sections and those discussed in the present one is that, in the latter case, the argument starts from a non-excused breach of a primary norm, and it seeks to limit or apportion its monetary consequences. Several concepts have been discussed in the case law, including references to the "clean hands" doctrine, contributory fault, the duty to mitigate damages, abuse of right and, more generally, the negligence of

\footnotetext{
436 General Dynamics v. Libya, paras. 264-7. $\quad 437$ Himpurna case, paras. 130, $193-4$.

438 Himpurna case, para. 195.439 General Dynamics v. Libya, paras. 285-8.

440 General Dynamics v. Libya, paras. 334-7.

441 Himpurna case, para. 318 (explaining the rationale of the reduction).
} 
the claimant. Although tribunals may, at times, address them together, these concepts are distinct, and each faces its own challenges. The "clean hands" doctrine operates as a component of other defence arguments (e.g. the requirement, for the availability of the customary defence of necessity, that the party invoking it must not have contributed to the situation of necessity) and, possibly, on a stand-alone basis, although tribunals have sometimes denied the latter possibility. ${ }^{442}$ Contributory fault, as characterised in Article 39 of the ILC Articles on State Responsibility, can provide a basis to reduce the quantum owed to the claimant if the latter's behaviour bears a clear causal relationship with the challenged measure and a portion of the harm suffered is severable. The duty to mitigate the damage does not concern the contribution of the claimant to its mistreatment but its lack of diligence in mitigating the harm caused by it. The doctrine of abuse of right may be relied on not only to penalise the misconduct of a party but to pre-empt it by rejecting a potential misuse of a right to be compensated. ${ }^{443}$ Investor negligence is a wider notion regrouping several other concepts, and it can be taken into account in different forms and at different stages, including quantum. ${ }^{444}$ Therefore, in the following paragraphs, only the operation of the first three concepts is discussed. In all these cases, however, the underlying rationale is that those damages arising from a claimant's misconduct should not be compensated, either because such misconduct is (at least partially) their cause or because the overall damage could have been mitigated had the investor exercised the diligence that could be expected from it.

\section{CLEAN HANDS DOCTRINE}

139. Concerning the "clean" or indeed "unclean" hands doctrine, the matter has featured prominently in three investment cases against the Russian Federation over the expropriation of Yukos, ${ }^{445}$ which are reported in this volume. In the Yukos cases, after joining the objection to the discussion on the merits, the tribunal rejected it as such but took into account the tax avoidance actions of Yukos in its analysis of contributory fault. For present purposes, the relevant sections of the awards are those where the tribunals discuss the existence of the "unclean hands" doctrine as a general principle of law in the meaning of Article 38(1)(c) of the ICJ Statute. ${ }^{446}$ The analysis is rigorous and considers many decisions from the ICJ and its predecessor, the PCIJ, before rejecting the existence of such a rule. ${ }^{447}$ It may be noted however that, in reaching its conclusion, the tribunal overemphasised the lack of recognition of the unclean hands doctrine by a majority in a court or tribunal (by contrast with dissenting opinions). It did not seek to analyse the practice in foro domestico or the potential transposal of such a principle to the international plane, as the very concept of a general principle of law would require.

\footnotetext{
442 See e.g. Lao Holdings v. Laos, para. 106. $\quad{ }_{443}^{4}$ Himpurna case, para. 330.

444 The following discussion relies on Viñuales 2017.

445 See Hulley v. Russia, paras. 1358-73; Yukos v. Russia, paras. 1358-73; Veteran Petroleum v. Russia, paras. 1358-73.

446 Statute of the International Court of Justice, 26 June 1945, 33 UNTS $993 . \quad 447$ See note 453.
} 
140. Another illustration is provided by the Copper Mesa v. Ecuador case, where the tribunal characterised the objection derived from the clean hands doctrine as one of inadmissibility and then, after considering that it was too late in the proceedings to raise such an objection, assimilated a number of different concepts (unclean hands, causation, contributory fault) as materially equivalent and left the matter for the discussion of liability/quantum. ${ }^{448}$ It is noteworthy - and rather perplexing - that, despite a factual finding that the investor had "resort[ed] to recruiting and using armed men, firing guns and spraying mace at civilians, not as an accidental or isolated incident but as part of premeditated, disguised and well-funded plans to take the law into its own hands" 449 the tribunal nevertheless deemed the claim relating to that portion of the investment admissible and simply reduced the compensation due as a matter of contributory fault.

141. In a more recent award, the tribunal in Lao Holdings v. Laos confirmed the conclusion in Yukos that the "clean hands" doctrine has a dubious basis in international law but that its rationale remains operative as a matter of equity:

The Respondent also relies on a generalized doctrine of "clean hands" which is a metaphor employed as a defence to equitable relief in common law jurisdictions. Incorporation of such a general doctrine into investor-State law without careful boundaries would risk opening investment disputes to an open-ended, vague and ultimately unmanageable principle. However, putting aside the label, serious financial misconduct by the Claimants incompatible with their good faith obligations as investors in the host country (such as criminality in defrauding the host Government in respect of an investment) is not without Treaty consequences, both in relation to their attempt to rely on the guarantee of fair and equitable treatment, as well as their entitlement to relief of any kind from an international tribunal. ${ }^{450}$

\section{CONTRIBUTORY FAULT}

142. The concept of contributory fault has been used to reduce compensation by $25,{ }^{451} 30^{452}$ or even $50^{453}$ per cent and, in one case, to suppress compensation altogether. ${ }^{454}$ A line can be drawn in this regard going from cases such as MTD v. Chile, to Occidental v. Ecuador, the Yukos cases and Al-Warraq v. Indonesia as well as Copper Mesa v. Ecuador. MTD v. Chile is often relied on as a precedent in this matter. In this case, the tribunal considered that the investor, which had acted negligently in assessing regulatory risks affecting the acquisition of a plot of land for further development, had to bear part of the damages that it had suffered.

\footnotetext{
448 See Copper Mesa v. Ecuador, paras. 5.62-5.66.

449 Copper Mesa v. Ecuador, para. 6.99.

450 Lao Holdings v. Laos, para. 106.

451 Occidental Petroleum Corporation and Occidental Exploration and Production Company v. The Republic of Ecuador, ICSID Case No. ARB/06/11, Award (5 October 2012) [Occidental v. Ecuador], para. 687; Hulley v. Russia, para. 1637; Yukos v. Russia, para. 1637; Veteran Petroleum v. Russia, para. 1274.

452 Copper Mesa v. Ecuador, para. 6.102.

453 MTD Equity Sdn Bhd and MTD Chile SA v. Republic of Chile, ICSID Case No. ARB/01/7, Award (25 May 2004) [MTD v. Chile], paras. 242-3.

454 Hesham Talaat M. Al-Warraq v. Republic of Indonesia, UNCITRAL, Final Award (15 December 2014) [Al-Warraq v. Indonesia], para. 683, point 6 (for the claim relating to breach of fair and equitable treatment).
} 
The tribunal reasoned that such damage was attributable to business risk because the investor could have mitigated it if it had deployed better business judgement:

The Tribunal decided earlier that the Claimants incurred costs that were related to their business judgment irrespective of the breach of fair and equitable treatment under the BIT. As already noted, the Claimants, at the time of their contract with Mr. Fontaine, had made decisions that increased their risks in the transaction and for which they bear responsibility, regardless of the treatment given by Chile to the Claimants. They accepted to pay a price for the land with the Project without appropriate legal protection. A wise investor would not have paid full price up-front for land valued on the assumption of the realization of the Project; he would at least have staged future payments to project progress, including the issuance of the required development permits ... The Tribunal considers therefore that the Claimants should bear part of the damages suffered and the Tribunal estimates that share to be $50 \%$ after deduction of the residual value of their investment calculated on the basis of the following considerations. ${ }^{455}$

The key consideration in the reasoning offered by the tribunal is the distinction between business judgement, which is a matter of commercial risk, and the compensable political risk.

143. Another well-known illustration is Occidental v. Ecuador. In this case, the claimant had transferred its rights over a portion of an oil block without the required authorisation of the government officials. Such conduct enabled the operation of a clause authorising the rescinding of the governing contract. The tribunal found that, in the specific factual context, the exercise of such contractual right by the governmental authority had been disproportionate but it nevertheless reasoned that the investor had contributed to this measure as a result of its negligence. For present purposes, the main elements that can be derived from this decision are the conditions for the operation of Article 39 of the ILC Articles on State Responsibility, which the tribunal read in conjunction with Article 31. Three main components of this test can be identified namely (i) negligence must be of some degree, (ii) it must bear a material or significant causal relationship with the challenged measure, and (iii) some part of the injury must be shown to be severable in causal terms from the injury caused by the host State. ${ }^{456}$ The tribunal asserted "discretion" as to the apportionment of the damage. ${ }^{457}$ Subsequent decisions have added some further refinements. In the Yukos awards, contributory fault was distinguished from the duty to mitigate damages ${ }^{458}$ and, in Copper Mesa v. Ecuador, the tribunal suggested that when the investor's fault (component (i) above) goes beyond negligence it may have "much graver" consequences. ${ }^{459}$

$455 M T D$ v. Chile, paras. 242-3. The damages assessment of the tribunal withstood an annulment challenge, see MTD Equity Sdn Bhd and MTD Chile SA v. Chile, ICSID Case No. ARB/01/7, Decision on Annulment (16 February 2007) [MTD v. Chile - Annulment], para. 101.

456 Occidental v. Ecuador, paras. 665-8. 457 Occidental v. Ecuador, para. 670.

458 Hulley v. Russia, para. 1603; Yukos v. Russia, para. 1603; Veteran Petroleum v. Russia, para. 1603. Although the reasoning is not entirely clear on this point, the main dividing line seems to be the causal link between the investor's "fault" and the State's wrongful act (para. 1608) whereas the duty to mitigate damages intervenes in the absence of such causal link and after the State's wrongful act has occurred.

459 Copper Mesa v. Ecuador, para. 6.100. 
144. The latter point can be illustrated by reference to the exceptional approach followed by the tribunal in Al-Warraq v. Indonesia. In this case, the tribunal found that the State had breached its fair and equitable treatment obligation under the applicable treaty (imported through an MFN clause) and even a provision (Article 14) of the International Covenant on Civil and Political Rights, ${ }^{460}$ although the tribunal did not assert jurisdiction over this instrument. However, because of the reckless financial practices of the investor, which the tribunal considered to be in breach of an unusual provision (Article 9) of the applicable treaty requiring the investor to comply with domestic regulations, a majority of the tribunal concluded that "for this reason [the Claimant] is not entitled to any damages in respect of the Respondent's breaches of the fair and equitable treatment standard". ${ }^{461}$ This is a remarkable development because the treaty clause in question simply states that investors must respect the domestic laws and regulations for the protection of the public interest. ${ }^{462}$

\section{DUTY TO MITIGATE DAMAGES}

145. Even in the absence of contributory fault, compensation may be reduced as a result of the investor's duty to mitigate the damages suffered. There is an abundant body of cases providing authority to the existence of such a duty. ${ }^{463}$ The principle was suitably formulated in a case against Slovenia where, discussing mitigation, the tribunal noted that "general principles of international law applicable in this case require an innocent party to act reasonably in attempting to mitigate its losses" and buttressed this observation by a reference to the commentary to Article 31 of the ILC Articles. ${ }^{464}$ The negligence involved here (rejected in casu) relates to the conduct of the aggrieved party when facing the wrongful act. That conduct must remain reasonable ${ }^{465}$ and the burden of proving negligence is

460 International Covenant on Civil and Political Rights, 16 December 1966, 999 UNTS 171 [ICCPR]. 461 Al-Warraq v. Indonesia, para. 683, point 6. The respondent alleged corruption in violation of Article 9 as a jurisdictional defence but the tribunal felt the need to "look closely at the Parties' claims" (para. 99) and left the matter to the merits stage.

462 Specifically, Article 9 of the Agreement on Promotion, Protection and Guarantee of Investments among Member States of the Organisation of the Islamic Conference, June 1981, states: "The investor shall be bound by the laws and regulations in force in the host state and shall refrain from all acts that may disturb public order or morals or that may be prejudicial to the public interest. He is also to refrain from exercising restrictive practices and from trying to achieve gains through unlawful means."

463 See Saar Papier Vertriebs GmbH v. Republic of Poland, Award (16 October 1995) [Saar Papier v. Poland], paras. 98-102; Middle East Cement Shipping and Handling Co. S.A. v. Egypt, ICSID Case No. ARB/99/6, Award (12 April 2002) [Middle East Cement v. Egypt], paras. 166-71; CME v. Czech Republic, paras. 482-3; EDF International SA, SAUR International SA and Leon Participaciones Argentinas SA v. Argentina, ICSID Case No. ARB/03/23, Award (11 June 2012) [EDF v. Argentina], paras. 1302-31; Hulley v. Russia, para. 1776; Yukos v. Russia, para. 1776; Veteran Petroleum v. Russia, para. 1776; Hrvatska Elektroprivreda D.D. v. Republic of Slovenia, ICSID Case No. ARB/05/24, Award (17 December 2015) [Hrvatska v. Slovenia], para. 215.

464 Hrvatska v. Slovenia, paras. 215, 386. See also EDF v. Argentina, para. 1302 (referring to Article 31 of the ILC Articles on State Responsibility); Middle East Cement v. Egypt, para. 167.

465 See also Saar Papier v. Poland, para. 98 (implying a duty of due diligence on the investor); CME v. Czech Republic, paras. 482-3; National Grid plc v. Argentina, UNCITRAL Rules, Award (3 November 2008), para. 273; EDF v. Argentina, para. 1306; Achmea B.V. v. Slovak Republic, PCA Case No. 2008-13, Award (7 December 2012), para. 320. 
on the respondent. ${ }^{466}$ Of note is that the tribunal assumed that a duty of mitigation normally applicable to States also applies to investors. This is an indication that there may be many other duties that, through analogical reasoning, could be extended to govern the conduct of investors.

146. One illustration of the effects of this principle - and of how far its effects can go - is provided by EDF v. Argentina. In this case, the tribunal considered that the investor had failed in its duty to mitigate damage because, in selling its shares in the investment vehicle to another shareholder, it had kept only its claims in the arbitration and left any possible benefit from a successful renegotiation of the tariff to the buyer of the shares. ${ }^{467}$ As a result, the tribunal concluded that an amount equal to 50 per cent of the value of investor participation in the vehicle had to be deducted from the damages awarded. ${ }^{468}$

\section{CONCLUDING OBSERVATIONS}

147. The foregoing analysis illustrates the wide range of defence arguments based on both international and domestic law which have featured in the case law of investment arbitration tribunals. It also shows the plasticity of their operation, which often unfolds at different stages of the proceedings depending on how the defence argument is framed. Over time, the case law has refined the understanding of how each argument operates, although in some cases it has also blurred the boundaries between some of them. In this overall context, this study is an effort not only to present the main concepts discussed in the decisions reported in this volume or to place them in their wider jurisprudential context but also, above all, to organise them following the analytical cartography introduced in Figure 3.

148. Given the volatility of the case law, it appears indeed important to keep the wood in sight when considering each one of the trees. Some defence arguments operate at the level of the primary norm whereas others only come into play at the level of secondary norms. Conflating these stages is not only a potentially annullable error or deficiency but, more generally, mischaracterises the operation of defence arguments in important ways, whether technically (e.g. the definition of the "requirements", the allocation of the burden of proof, the sequence of application, etc.) and/or practically (e.g. the interpretation approach or the level of deference). That, in turn, has wider practical implications at the level of costs, with proceedings which may become potentially longer and costlier, but also, more fundamentally, for the expression of the values protected by different defence arguments and, ultimately, for the overall legitimacy of investment arbitration as a means of international dispute settlement.

149. The distinctions in Figure 3 and subsequently applied in the analysis suggest that the operation of defence arguments can and should be argued not only on the basis of references to the case law, which sometimes points in different directions, but on a principled basis. Such arguments have roots which are deeper 
than a mere discussion in one case or the other, and it is important to unveil and spell out such roots for the operation of each argument in order to rely on a general systemic reasoning.

150. There is an increasing demand for principled and stable reasoning regarding the operation of certain defence arguments, particularly those which give expression to broader concepts such as State sovereignty or the rule of law. The investment arbitration system should do more to meet this demand or the system may face a strong backlash and lose ground to more organised and centralised dispute settlement systems currently under discussion. It is not sufficient to tackle issues of consistency by reference to fundamental changes in the macro structure of international investment law; much indeed depends on the systemic implications of sedimented decisions which at present do not always attempt to provide principled answers to the questions raised by the case law. ${ }^{469}$ Even for concepts as diverse as the broad category of defence arguments addressed in this preliminary study, principled reasoning can make a useful contribution to the demand for a reasonable degree of predictability. Investment arbitration will continue to be highly factdependent and casuistic, but major ambiguities and problematic positions that, through sedimentation, may be unsettling the balance of the overall system, can be avoided or looked at afresh if the argument is based on a principled basis.

\section{Appendix}

\section{List of Cases Covered in this study}

NB: cases in the ICSID Reports are in bold type and those reported in this volume are marked with $(*)$

\section{PERMANENT COURT OF INTERNATIONAL JUSTICE}

Case relating to the Territorial Jurisdiction of the International Commission of the River Oder, Judgment (10 September 1929), P.C.I.J. Reports Series A No. 23

Certain German Interests in Polish Upper Silesia (Merits), Judgment (25 May 1926), P.C.I.J. Series A No. 7

Oscar Chinn Case, Judgment (12 December 1934) P.C.I.J. Series A/B No. 63

\section{INTERNATIONAL COURT OF JUSTICE}

Barcelona Traction, Light and Power Company, Limited, Judgment, I.C.J. Reports 1970, p. 3

469 See generally Viñuales 2018. 
Delimitation of the Maritime Boundary in the Gulf of Maine Area (Canada/ United States of America), Judgment, I.C.J. Reports 1984, p. 305

Gabčíkovo-Nagymaros Project (Hungary/Slovakia), I.C.J. Reports 1997, p. 7

Land and Maritime Boundary between Cameroon and Nigeria (Cameroon v. Nigeria), Preliminary Objections, Judgment, I.C.J. Reports 1998, p. 303

Land, Island and Maritime Frontier Dispute (El Salvador/Honduras), Application to Intervene, Judgment, I.C.J. Reports 1990, p. 118

Legality of the Threat or Use of Nuclear Weapons, Advisory Opinion, I.C.J. Reports 1996, p. 226

Military and Paramilitary Activities in and against Nicaragua (Nicaragua v. United States of America), Jurisdiction and Admissibility, Judgment, I.C.J. Reports 1984, p. 392

Military and Paramilitary Activities in and against Nicaragua (Nicaragua v. United States of America), Merits, Judgment, I.C.J. Reports 1986, p. 14 North Sea Continental Shelf, Judgment, I.C.J. Reports 1969, p. 3

Obligation to Negotiate Access to the Pacific Ocean (Bolivia v. Chile), Judgment of 1 October 2018, I.C.J. General List No. 153

Oil Platforms (Islamic Republic of Iran v. United States of America), Judgment, I.C.J. Reports 2003, p. 16

Sovereignty over Pedra Branca/Pulau Batu Puteh, Middle Rocks and South Ledge (Malaysia/Singapore), Judgment, I.C.J. Reports 2008, p. 51

Sovereignty over Pulau Ligitan and Pulau Sipadan (Indonesia/Malaysia), Judgment, I.C.J. Reports 2002, p. 625

Temple of Preah Vihear (Cambodia v. Thailand), Judgment, I.C.J. Reports 1962, p. 6

Territorial and Maritime Dispute (Nicaragua v. Colombia), Judgment, I.C.J. Reports 2012, p. 624

Legal Consequences of the Construction of a Wall in the Occupied Palestinian Territory, Advisory Opinion, I.C.J. Reports 2004, p. 136

\section{INVESTMENT ARBITRATION AWARDS}

Aaron C. Berkowitz, Brett E. Berkowitz and Trevor B. Berkowitz (formerly Spence International Investments and others) v. Republic of Costa Rica, ICSID Case No. UNCT/13/2, Interim Award on Jurisdiction (25 October 2016)

Accession Mezzanine Capital L.P. and Danubius Kereskedohaz Vagyonkezelo v. Hungary, ICSID Case No. ARB/12/3, Decision on Respondent's Objection under Arbitration Rule 41(5) (16 January 2013)

Achmea B.V. v. Slovak Republic, PCA Case No. 2008-13, Award (7 December 2012)

ADC Affiliate Ltd and ADC \& ADMC Management Ltd v. Republic of Hungary, ICSID Case No. ARB/03/16, Award (2 October 2006) 15 ICSID Rep 536 
ADF Group Inc. v. United States of America, ICSID Case No. ARB(AF)/00/1, Award (9 January 2003) 6 ICSID Rep 470

Al Tamimi v. Sultanate of Oman, ICSID Case No. ARB/11/33, Award (3 November 2015)

American Manufacturing \& Trading, Inc. v. Republic of Zaire, ICSID Case No. ARB/93/1, Award (21 February 1997) 5 ICSID Rep 14

Anderson et al. v. Costa Rica, ICSID Case No. ARB(AF)/07/3, Award (19 May 2010)

Antaris Solar GmbH and Dr. Michael Göde v. Czech Republic, PCA Case No.

2014-01, Award (2 May 2018) 18 ICSID Rep 681 (*)

Apotex Inc. v. United States, UNCITRAL Rules, Award on Jurisdiction and Admissibility (14 June 2013)

Archer Daniels Midland Company and Tate \& Lyle Ingredients Americas, Inc.

v. United Mexican States, ICSID Case No. ARB(AF)/04/5, Award (21 November 2007)

Asian Agricultural Products Ltd (AAPL) v. Republic of Sri Lanka, ICSID Case

No. ARB/87/3, Final Award (27 June 1990) 4 ICSID Rep 250

Awdi, Enterprise Business Consultants, Inc. and Alfa El Corporation v. Romania, ICSID Case No. ARB/10/13, Award (2 March 2015)

Bankswitch Ghana Ltd v. The Republic of Ghana, UNCITRAL, Award (11 April 2014) 18 ICSID Rep 303 (*)

Bernhard von Pezold and others v. Republic of Zimbabwe, ICSID Case No. ARB/10/15, Award (28 July 2015) 18 ICSID Rep 360 (*)

BG Group Plc. v. Republic of Argentina, UNCITRAL, Award (24 December 2007), para. 268; AWG Group Ltd v. Argentine Republic, UNCITRAL, Decision on Liability (30 July 2010)

Burlington Resources v. Ecuador, ICSID Case No. ARB/08/5, Decision on Jurisdiction (2 June 2010)

Burlington Resources Inc. v. Republic of Ecuador, ICSID Case No. ARB/08/5,

Decision on Counterclaims (7 February 2017)

Canfor Corporation v. United States of America and Terminal Forest Products Ltd v. United States of America, NAFTA (UNCITRAL Rules), Decision on Preliminary Question (6 June 2006)

Cargill, Incorporated v. United Mexican States, ICSID Case No. ARB(AF)/05/ 2, Award (18 September 2009) 18 ICSID Rep 199 (*)

CC/Devas (Mauritius) Ltd., Devas Employees Mauritius Private Limited and Telcom Devas Mauritius Limited v. Republic of India, PCA Case No. 201309, Award on Jurisdiction and Merits (25 July 2016) 18 ICSID Rep 487 (*) Chemtura Corporation (formerly Crompton Corporation) v. Government of Canada, UNCITRAL, Award (2 August 2010)

Chevron Corporation (USA) and Texaco Petroleum Company (USA) v. The Republic of Ecuador, UNCITRAL, PCA Case No. 34877, Interim Award (1 December 2008)

Churchill Mining PLC and Planet Mining Pty Ltd v. Republic of Indonesia, ICSID Case Nos. ARB/12/14 and 12/40, Award (6 December 2016) 18 ICSID Rep 527 (*) 
CME Czech Republic B.V. v. The Czech Republic, UNCITRAL Rules, Partial Award (13 September 2001) 9 ICSID Rep 121

CMS Gas Transmission Company v. The Republic of Argentina, ICSID Case No. ARB/01/8, Award (12 May 2005) 14 ICSID Rep 158

CMS Gas Transmission Company v. Argentine Republic, ICSID Case No. ARB/01/08, Decision on Annulment (25 September 2007) 14 ICSID Rep 251

Continental Casualty Company v. The Argentine Republic, ICSID Case No. ARB/03/9, Award (5 September 2008) 18 ICSID Rep 155 (*)

Continental Casualty Company v. The Argentine Republic, ICSID Case No. ARB/03/9, Decision on the Application for Partial Annulment of Continental Casualty Company and the Application for Partial Annulment of the Argentine Republic (16 September 2011) 18 ICSID Rep 155 (*)

Copper Mesa Mining Corporation v. Republic of Ecuador, UNCITRAL, PCA No. 2012-2, Award (15 March 2016)

Corn Products International Inc. v. United Mexican States, ICSID Case No. ARB(AF)/04/1, Decision on Responsibility (15 January 2008)

Cortec Mining Kenya Limited, Cortec (Pty) Ltd and Stirling Capital Ltd v. Republic of Kenya, ICSID Case No. ARB/15/29, Award (22 October 2018) 18 ICSID Rep 741 (*)

Duke Energy Electroquil Partners \& Electroquil S.A. v. Republic of Ecuador, ICSID Case No. ARB/04/19, Award (18 August 2008) 15 ICSID Rep 146 ECE Projektmanagement International GmbH and Kommanditgesellschaft PANTA Achtundsechzigste Grundstücksgesellschaft $m b H \&$ Co. v. Czech Republic, PCA Case No. 2010-5, Award (19 September 2013)

EDF (Services) Ltd v. Romania, ICSID Case No. ARB/05/13, Award (8 October 2009)

EDF International SA, SAUR International SA and Leon Participaciones Argentinas SA v. Argentina, ICSID Case No. ARB/03/23, Award (11 June 2012)

Eiser Infrastructure Limited and Energía Solar Luxembourg S.à.r.l. v. Kingdom of Spain, ICSID Case No. ARB/13/36, Final Award (4 May 2017)

El Paso Energy International Co. v. Argentine Republic, ICSID Case No. ARB/03/15, Award (31 October 2011)

EnCana Corporation v. Republic of Ecuador, LCIA Case No. UN3481, UNCITRAL Rules, Award (3 February 2006) 12 ICSID Rep 427

Enka Inşaat ve Sanayi A.Ş. v. The Gabonese Republic, ICC Arbitration No. 22841/DDA, Final Award (14 September 2018) 18 ICSID Rep 716 (*)

Enron Corporation and Ponderosa Assets, L.P. v. Argentine Republic, ICSID Case No. ARB/01/3, Award (22 May 2007)

Enron Corporation and Ponderosa Assets, L.P. v. Argentine Republic, ICSID Case No. ARB/01/3, Decision on the Application for Annulment of the Argentine Republic (30 July 2010)

Europe Cement Investment and Trade S.A. v. Republic of Turkey, ICSID Case No. ARB(AF)/07/2, Award (13 August 2009) 
Fraport AG Frankfurt Airport Services Worldwide v. Republic of the Philippines, ICSID Case No. ARB/03/25, Award (16 August 2007)

General Dynamics United Kingdom Ltd v. The State of Libya, ICC Arbitration Case No. 19222/EMT, Final Award (5 January 2016) 18 ICSID $\operatorname{Rep} 421$ (*)

Glamis Gold Ltd v. The United States of America, NAFTA Arbitration (UNCITRAL), Award (16 May 2009)

Grand River Enterprises Six Nations Ltd et al. v. United States of America, UNCITRAL, Decision on Objections to Jurisdiction (20 July 2006) 15 ICSID Rep 505

Hamester GmbH \& Co. KG v. Republic of Ghana, ICSID Case No. ARB/07/ 24, Award (18 June 2010)

Hesham Talaat M. Al-Warraq v. Republic of Indonesia, UNCITRAL, Final Award (15 December 2014)

Himpurna California Energy Ltd (Bermuda) v. PT (Pesero) Perrusahaan Listruik Negara (Indonesia), UNCITRAL Rules, Award (4 May 1999)

HOCHTIEF Aktiengesellschaft v. Argentine Republic, ICSID Case No. ARB/ 07/31, Decision on Liability (29 December 2014)

Hrvatska Elektroprivreda D.D. v. Republic of Slovenia, ICSID Case No. ARB/ 05/24, Award (17 December 2015)

Hulley Enterprises Limited (Cyprus) v. The Russian Federation, UNCITRAL, PCA Case No. AA 226, Final Award (18 July 2014) 18 ICSID Rep 331 (*)

Inceysa Vallisoletana S.L. v. Republic of El Salvador, ICSID Case No ARB/03/ 26, Award (2 August 2006) 17 ICSID Rep 105

Karkey Karadeniz Elektrik Uretim A.S. v. Islamic Republic of Pakistan, ICSID Case No. ARB/13/1, Award (22 August 2017) 18 ICSID Rep 600 (*)

Kim and others v. Republic of Uzbekistan, ICSID Case No. ARB/13/6, Decision on Jurisdiction (8 March 2017)

Lao Holdings N.V. v. Lao People's Democratic Republic, ICSID Case No. $\mathrm{ARB}(\mathrm{AF}) / 12 / 6$, Award (6 August 2019)

Les Laboratoires Servier, S.A.S., Biofarma, S.A.S., Arts et Techniques du Progres S.A.S. v. Republic of Poland, UNCITRAL, Award (Redacted) (14 February 2012)

$L G \& E$ Energy Corp, LG\&E Capital Corp, LG\&E International Inc. v. Argentine Republic, ICSID Case No. ARB/02/1, Decision on Liability (3 October 2006)

Libananco Holdings Co. Limited v. Republic of Turkey, ICSID Case No. ARB/ 06/7, Award (2 September 2011)

Malicorp Limited v. Arab Republic of Egypt, ICSID Case No. ARB/08/18, Award (7 February 2011)

Mamidoil Jetoil Greek Petroleum Products Société Anonyme S.A. v. Republic of Albania, ICSID Case No. ARB/11/24, Award (30 March 2015)

Marvin Roy Feldman Karpa v. United Mexican States, ICSID Case No. ARB (AF)/99/1, Award (16 December 2002) 7 ICSID Rep 341

M.C.I. Power Group L.C. and New Turbine Inc. v. Republic of Ecuador, ICSID Case No. ARB/03/6, Award (31 July 2007) 
Mercer International Inc. v. Government of Canada, ICSID Case No. ARB (AF)/12/3, Award (8 March 2018) 18 ICSID Rep 657 (*)

Mesa Power Group, LLC v. Government of Canada, UNCITRAL, PCA Case No. 2012-17, Award (24 March 2016)

Metalpar v. Argentine Republic, ICSID Case No. ARB/03/5, Award (6 June 2008)

Metal-Tech Ltd v. Republic of Uzbekistan, ICSID Case No. ARB/10/3, Award (4 October 2013)

Methanex Corporation v. United States of America, NAFTA (UNCITRAL), Award (3 August 2005) 16 ICSID Rep 40

Middle East Cement Shipping and Handling Co. S.A. v. Egypt, ICSID Case No. ARB/99/6, Award (12 April 2002) 7 ICSID Rep 178

Minnotte and Robert Lewis v. Republic of Poland, ICSID Case No. ARB(AF)/ 10/1, Award (16 May 2014)

Mobil Corporation, Venezuela Holdings, B.V., Mobil Cerro negro Holding, Ltd., Mobil Venezolana de Petróleos Holdings, Inc., Mobil Cerro Negro, Ltd., and Mobil Venezolana de Petróleos, Inc. v. Bolivarian Republic of Venezuela, ICSID Case No. ARB/07/27, Decision on Jurisdiction (10 June 2010)

Mobil Investments Canada Inc. and Murphy Oil Corporation v. Government of Canada, ICSID Case No. ARB(AF)/07/4, Decision on Liability and on Principles of Quantum (22 May 2012) 18 ICSID Rep 226 (*)

MTD Equity Sdn Bhd and MTD Chile SA v. Republic of Chile, ICSID Case No. ARB/01/7, Award (25 May 2004) 12 ICSID Rep 6

MTD Equity Sdn Bhd and MTD Chile SA v. Chile, ICSID Case No. ARB/01/7, Decision on Annulment (16 February 2007) 13 ICSID Rep 500

National Grid plc v. Argentina, UNCITRAL Rules, Award (3 November 2008) Occidental Petroleum Corporation and Occidental Exploration and Production Company v. The Republic of Ecuador, ICSID Case No. ARB/06/11, Award (5 October 2012)

Oostergetel v. The Slovak Republic, UNCITRAL Final Award (3 April 2012)

Orascom TMT Investments S.à.r.l. v. People's Democratic Republic of Algeria, ICSID Case No. ARB/12/35, Final Award (31 May 2017) 18 ICSID Rep 584 (*)

Pac Rim Cayman LLC v. Republic of El Salvador, ICSID Case No. ARB/09/12, Decision on the Respondent's Jurisdictional Objections (1 June 2012)

Parkerings-Compagniet AS v. Republic of Lithuania, ICSID Case No. ARB/05/ 8, Award (11 September 2007)

Patrick Mitchell v. Democratic Republic of the Congo, ICSID Case No. ARB/ 99/7, Decision on the Application for Annulment of the Award (1 November 2006)

Perenco Ecuador Ltd v. The Republic of Ecuador and Empresa Estatal Petróleos del Ecuador (Petroecuador), ICSID Case No. ARB/08/6, Interim Decision on the Environmental Counterclaim (11 August 2015)

Philip Morris Asia Limited v. The Commonwealth of Australia, UNCITRAL, PCA Case No. 2012-12, Award on Jurisdiction and Admissibility (17 December 2015) 
Philip Morris Brand Sàrl (Switzerland), Philip Morris Products S.A. (Switzerland) and Abal Hermanos S.A. (Uruguay) v. Oriental Republic of Uruguay, ICSID Case No. ARB/10/7, Award (8 July 2016) 18 ICSID Rep 450 (*)

Phoenix Action, Ltd v. The Czech Republic, ICSID Case No. ARB/06/5, Award (15 April 2009)

Plama Consortium Limited v. Bulgaria, ICSID Case No. ARB/03/24, Award (27 August 2008) 17 ICSID Rep 664

Pope \& Talbot Inc. v. Canada, NAFTA Case (UNCITRAL Rules), Award in Relation to Preliminary Motion by the Government of Canada (24 February 2000) 7 ICSID Rep 64

Pope and Talbot Inc. v. Government of Canada, NAFTA Case (UNCITRAL Rules), Interim Award (26 June 2000) 7 ICSID Rep 69

Quiborax S.A. and Non Metallic Minerals S.A. v. Plurinational State of Bolivia, ICSID Case No. ARB/06/2, Award (16 September 2015) 18 ICSID Rep $393(*)$

Renee Rose Levy and Gremcitel SA v. Republic of Peru, ICSID Case ARB/11/ 17, Award (9 January 2015)

Renta 4 S.V.S.A et al. v. Russian Federation, SCC Case No. 24/2007, Award (20 July 2012)

Revere Copper and Brass, Inc. v. Overseas Private Investment Corporation, Arbitration Tribunal, 24 August 1978, 56 I.L.R. 258

Ronald S. Lauder v. The Czech Republic, UNCITRAL Rules, Final Award (3 September 2001) 9 ICSID Rep 66

Rusoro Mining Ltd v. Bolivarian Republic of Venezuela, ICSID Case No. ARB (AF)/12/5, Award (22 August 2016)

Saar Papier Vertriebs GmbH v. Republic of Poland, Award (16 October 1995) Saba Fakes v. Republic of Turkey, ICSID Case No. ARB/07/20, Award (14 July 2010)

Saluka Investments B.V. v. The Czech Republic, UNCITRAL Rules, Decision on Jurisdiction over the Czech Republic's Counterclaim (7 May 2004) 15 ICSID Rep 256

Saluka Investments B.V. v. The Czech Republic, UNCITRAL, Partial Award (17 March 2006) 15 ICSID Rep 274

SAUR International S.A. v. Argentine Republic, ICSID Case No. ARB/04/4, Decision on Jurisdiction and Liability (6 June 2012)

Sempra Energy International v. The Argentine Republic, ICSID Case No. ARB/02/16, Award (28 September 2007) 18 ICSID Rep 111 (*)

Sempra Energy International v. The Argentine Republic, ICSID Case No. ARB/02/16, Decision on the Argentine Republic's Application for the Annulment of the Award (29 June 2010) 18 ICSID Rep 111 (*)

Sergei Paushok, CJSC Golden East Company and CJSC Vostokneftegaz Company v. The Government of Mongolia, UNCITRAL Rules, Award on Jurisdiction and Liability (28 April 2011)

Southern Pacific Properties (Middle East) Limited (SPP) v. Arab Republic of Egypt, ICSID Case No. ARB/84/3, Award (20 May 1992) 3 ICSID Rep 189 
Spyridon Roussalis v. Romania, ICSID Case No. ARB/06/1, Award (7 December 2011)

Suez, Sociedad General de Aguas de Barcelona S.A. and InterAgua Servicios Integrales del Agua S.A. v. Argentine Republic, ICSID Case No. ARB/03/ 17, Decision on Liability (30 July 2010)

Suez, Sociedad General de Aguas de Barcelona, S.A. and Vivendi Universal, S.A. v. Argentine Republic, ICSID Case No. ARB/03/19, Decision on Liability (31 July 2010)

Técnicas Medioambientales Tecmed S.A. v. United Mexican States, ICSID

Case No. ARB(AF)/00/2, Award (29 May 2003) 10 ICSID Rep 134

TECO Guatemala Holdings, LLC v. Republic of Guatemala, ICSID Case No. ARB/10/23, Award (19 December 2013)

Total S.A. v. Argentine Republic, ICSID Case No. ARB/04/01, Decision on Liability (27 December 2010)

Tza Yap Shum v. Peru, ICSID Case No. ARB/07/6, Award (7 July 2011)

$U A B$ E energija (Lithuania) v. Republic of Latvia, ICSID Case No. ARB/12/33,

Award, 22 December 201718 ICSID Rep 631 (*)

Urbaser S.A. and Consorcio de Aguas Bilbao Biskaia, Bilbao Biskaia Ur Partzuergoa v. Argentine Republic, Award (8 December 2016) 18 ICSID Rep 554 (*)

Veteran Petroleum Limited (Cyprus) v. The Russian Federation, UNCITRAL,

PCA Case No. AA 228, Final Award (18 July 2014) 18 ICSID Rep 331 (*)

Waguih Elie George Siag and Clorinda Vecchi v. Arab Republic of Egypt, ICSID Case No. ARB/05/15, Award (1 June 2009)

Waste Management, Inc. v. United Mexican States, NAFTA Arbitration, Case

No. ARB(AF)/00/3, Award (30 April 2004) 11 ICSID Rep 361

Way2B v. Libya, ICC Arbitration, Award (24 May 2018)

World Duty Free Company Limited v. Republic of Kenya, ICSID Case No. ARB/00/7, Award (4 October 2006) 17 ICSID Rep 212

Yukos Universal Limited (Isle of Man) v. The Russian Federation, PCA Case

No. AA 227, Final Award (18 July 2014) 18 ICSID Rep 331 (*)

\section{OTHER ARBITRATION AWARDS}

Alsop Case (United States of America v. Chile) (1911) XI RIAA 355

Carlos Butterfield \& Co. Case (1898) 2 Moore International Arbitrations 1184

Chagos Marine Protected Area (Republic of Mauritius v. United Kingdom),

PCA, Award (18 March 2015)

Gentini Case (Italy v. Venezuela) (1903) X RIAA 551

Giacopini Case (Italy v. Venezuela) (1903) X RIAA 594

Pious Fund Case (United States of America v. Mexico) (1902) IX RIAA 11

Tagliaferro Case (Italy v. Venezuela) (1903) X RIAA 592

Williams Case (1890) 4 Moore International Arbitrations 4181 


\section{HUMAN RIGHTS COURTS}

Brannigan and McBride v. The United Kingdom, ECtHR Application 14553/ 89, 14554/89, Judgment (25 May 1993)

Handyside v. United Kingdom, ECtHR Application No. 5493/72, Judgment (7 December 1976)

Ireland v. United Kingdom, ECtHR Application No. 5310/71, Judgment (18 January 1978)

Sawhoyamaxa Indigenous Community v. Paraguay, ICtHR Series C No. 146, Judgment (29 March 2006)

\section{WORLD TRADE ORGANIZATION'S DISPUTE SETTLEMENT ORGANS}

Canada - Certain Measures Affecting the Renewable Energy Generation Sector - Canada - Measures Relating to the Feed-In Tariff Program, WT/ DS412/AB/R, WT/DS426/AB/R (6 May 2013)

European Communities - Measures Affecting Asbestos and AsbestosContaining Products, WT/DS135/AB/R (12 March 2001)

India - Additional and Extra-Additional Duties on Imports from the United States, AB Report (17 November 2008), WT/DS360/AB/R

Thailand - Customs and Fiscal Measures on Cigarettes from the Philippines, WT/DS371/AB/R (17 June 2011)

United States - Standards for Reformulated and Conventional Gasoline, WT/ DS2/AB/R (29 April 1996)

\section{OTHER}

Brown v. Maryland, 25 U.S. (12 Wheat) 419

Sanum Investment Ltd v. The Government of the Lao People's Democratic Republic, Singapore Court of Appeal, [2016] SGCA 57, Judgment (29 September 2016) 